\title{
IPPRAISAL OF HYDROLOGIC INFORMATION NEEDED IN ANTICIPATION OF LIGNITE MINING IN LAUDERDALE COUNTY, TENNESSEE
}

U.S. GEOLOGICAL SURVEY Water-Resources Investigations $80-54$

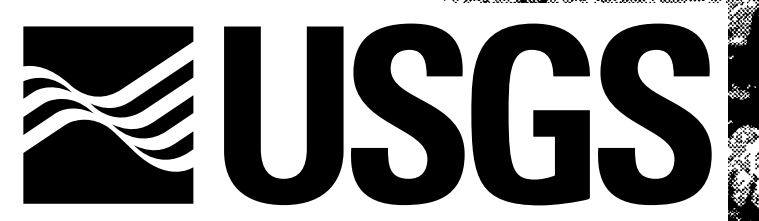

science for a changing world
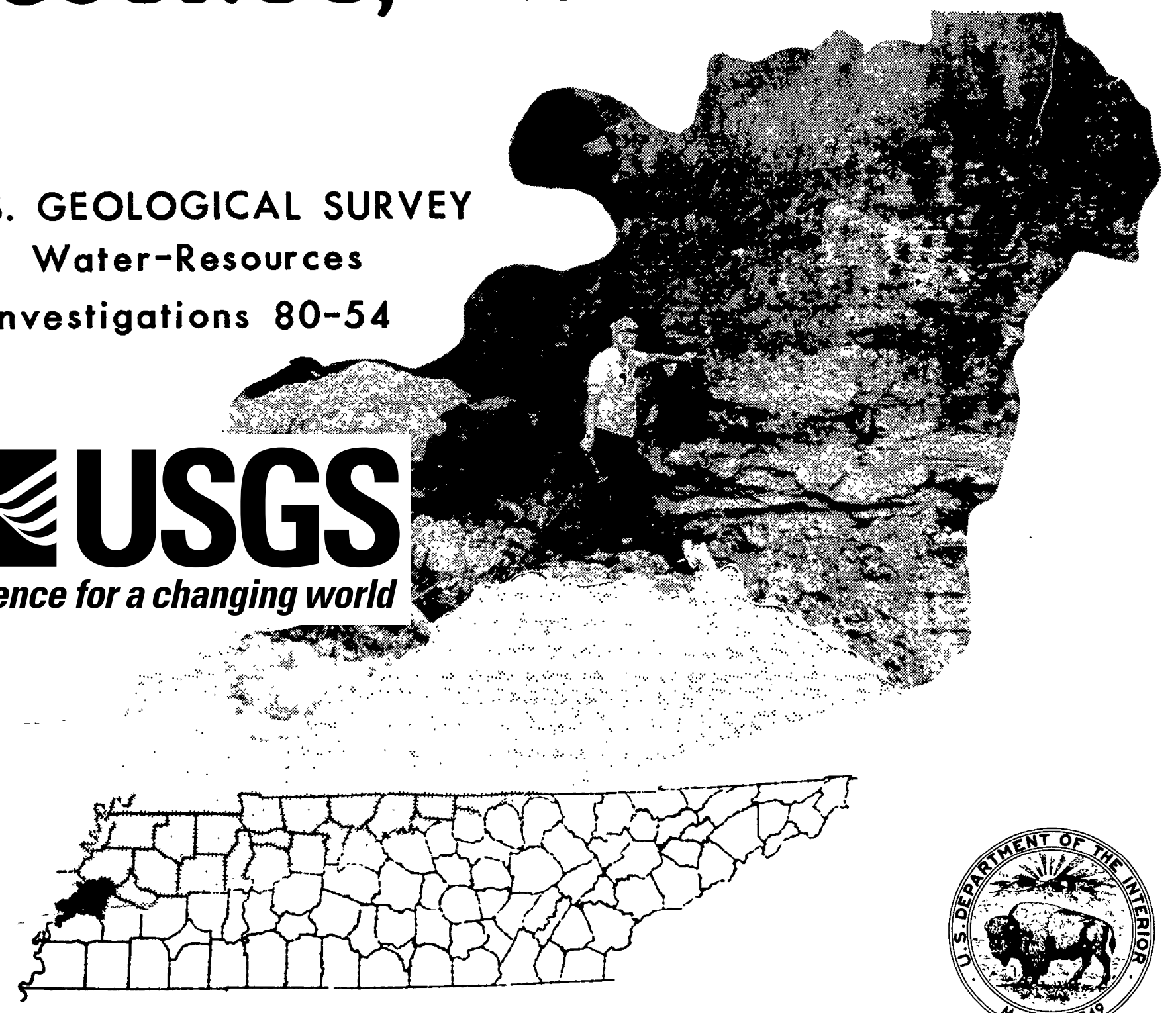

PREPARED IN COOPERATION WITH

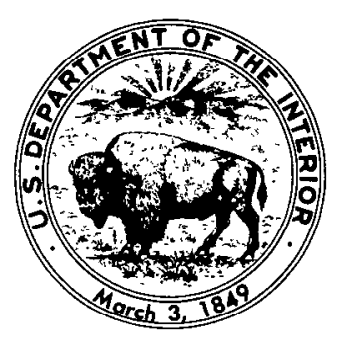

TENNESSEE DEPARTMENT OF CONSERVATION, DIVISION OF GEOLOGY 


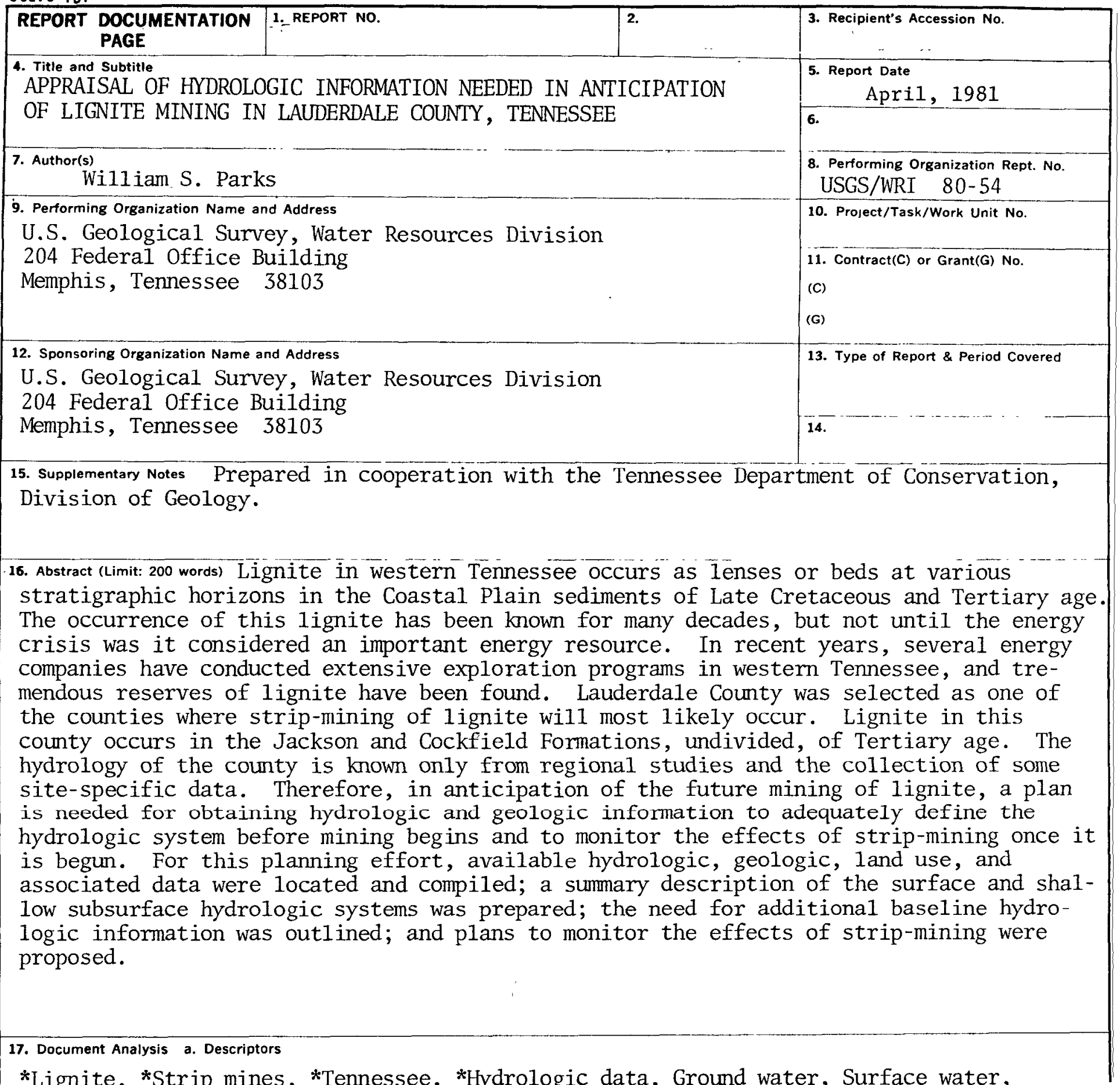

*Lignite, *Strip mines, *Tennessee, *Hydrologic data, Ground water, Surface water, Water quality.

b. Identifiers/Open-Ended Terms

*Lauderdale County, *Study plan.

c. COSATI Field/Group

18. Availability Statement

No restriction on distribution

\begin{tabular}{|l} 
19. Security Class (This Report) \\
UNCLASSIFIED \\
$\begin{array}{l}\text { 20. Security Class (This Page) } \\
\text { UNCLASSIFIED }\end{array}$ \\
\hline
\end{tabular}
UNCLASSIFIED 
APPRA ISAL OF HYDROLOGIC INFORMATION

NEEDED IN ANTICIPATION OF LIGNITE

MIN ING IN LAUDERDALE COUNTY, TENNESSEE

By William S. Parks

U.S. GEOLOGICAL SURVEY

Water-Resources Investigations

Open-File Report 80-54

Prepared in cooperation with the TENNESSEE DEPARTMENT OF CONSERVATION, DIVISION OF GEOLOGY

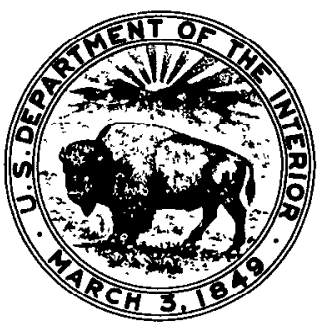


UN ITED STATES DEPARTMENT OF THE INTERIOR

JAMES G. WATT, Secretary

GEOLOGICAL SURVEY

Doyle G. Frederick, Acting Director

For additional information write to:

U.S. Geological Survey

A-413 Federal Building

U.S. Counthouse

Nashville, Tennessee 37203 


\section{CONTENTS}

Page

Abstract . . . . . . . . . . . . . . . . . . . . . . . . 1

Introduction . . . . . . . . . . . . . . . . . . . . . . . . . 1

Lignite in western Tennessee . . . . . . . . . . . . . . . . . . 1

Purpose and scope of this project . . . . . . . . . . . . . . .5

Location and size of project area . . . . . . . . . . . . . . 6

population and land use . . . . . . . . . . . . . . . . . . . 6

Availability of hydrologic information . - . . . . . . . . . . . . . . 8

Previous investigations . . . . . . . . . . . . . . . . . . . 8

Topographic and geologic maps . . . . . . . . . . . . . . . . . 9

Ground-water data . . . . . . . . . . . . . . . . . . . 11

Wel1 records . . . . . . . . . . . . . . . . . . 11

Geophysical logs . . . . . . . . . . . . . . . . . . 12

Water levels . . . . . . . . . . . . . . . . . . . . 12

Quality of water . . . . . . . . . . . . . . . . . . . 12

Pumping tests . . . . . . . . . . . . . . . . . . . 14

Surface-water data. . . . . . . . . . . . . . . . . . . . 14

Continuous-record gaging stations . . . . . . . . . . . . . 14

Partial-record gaging stations . . . . . . . . . . . . . . 18

Low-flow and miscellaneous sites . . . . . . . . . . . . . 19

Flood-prone area maps . . . . . . . . . . . . . . . . 19

Sediment data . . . . . . . . . . . . . . . . . . 21

Rainfall data . . . . . . . . . . . . . . . . . . . 21

Description of hydrologic system . . . . . . . . . . . . . . . . . 21

Geomorphic and geologic setting . . . . . . . . . . . . . . 21

Water use . . . . . . . . . . . . . . . . . . . . . . . 28

Ground-water system . . . . . . . . . . . . . . . . . 28

Mississippi alluvial deposits . . . . . . . . . . . . . . 37

Fluvial deposits . . . . . . . . . . . . . . . . . . . 37

Jackson and Cockfield Formations . . . . . . . . . . . . . 38

Memphis Sand... . . . . . . . . . . . . . . . . . . 38

Surface-water system . . . . . . . . . . . . . . . . . . . . 39

Drainage to Mississippi River . . . . . . . . . . . . . . . 39

Drainage to Hatchie River . . . . . . . . . . . . . . . . 42

Drainage to South Fork Forked Deer River . . . . . . . . . . . 43

Impact of strip-mining on the hydrologic system . . . . . . . . . . . 43

General considerations . . . . . . . . . . . . . . . . . . . 43

Mining in Mississippi Alluvial Plain . . . . . . . . . . . . . . . 44

Mining in Coastal Plain . . . . . . . . . . . . . . . . . . . . 45

Needs for bydrologic information and proposed data collection

activities . . . . . . . . . . . . . . . . . . . . . . . 45

Surface geologic maps . . . . . . . . . . . . . . . . . . . 45

Ground-water information . . . . . . . . . . . . . . . . . . . 46

Water-well inventory . . . . . . . . . . . . . . . . . 46

Subsurface stratigraphy . . - . - . - . - . - . . . . . . . . 47

Water-level trends and configurations . . . . . . . . . . . 48

Aquifer characteristics . . . . . . . . . . . . . . . . 51

Ground-water quality . . . . . . . . . . . . . . . . 52

Surface-water information . . . . . . . . . . . . . . . . . 53

Stream-flow characteristics . . . . . . . . . . . . . 53

Surface-water quality . . . . . . . . . . . . . . . . 56

Rainfall-runoff relations . . . . . . . . . . . . . . 58 
Plans to monitor strip-mining of lignite . . . . . . . . . . . . . . 59

Collection of mine-site data . . . . . . . . . . . . . . . . . 59

Application of computer modeling techniques . . . . . . . . . . 61

Summary of plan to study hydrology . . . . . . . . . . . . . . . . 6l

Selected references . . . . . . . . . . . . . . . . . . . 64

\section{ILLUSTRATIONS}

Figures 1-8. Maps showing:

1. Principal areas in western Tennessee where lignite is known to be relatively common and location of Lauderdale county . . . . . . . . . . . 2

2. Location and relative size of special land-use areas . . . . . . . . . . . . . . . 7

3. Topographic quadrangles available . . . . . . . 10

4. Wells and test holes for which geophysical logs are available... . . . . . . . . . . 13

5. Existing and discontinued stream-flow gaging stations and miscellaneous data-collection sites . . . . . . . . . . . . . . . . . 15

6. Weather stations of National Oceanic and Atmospheric Administration in vicinity of Lauderdale County . . . . . . . . . . . .

7. Generalized topography and major geomorphic subdivisions . . . . . . . . . . . . . . .

8. Regional setting of Lauderdale County in the Mississippi embayment and location of crosssection $A-A$ shown in figure 9 . . . . . . . . 25

9. Diagrammatic cross-section showing age of rocks of the Mississippi embayment--location shown in figure 8 . . . . . . . . . . . . . . . . . . . 26

10. Map showing generalized surface geology . . . . . . . . 27

11. Geohydrologic electric-log cross-section of western Tennessee through Lauderdale County . . . . . . . . . 29

12-15. Maps showing:

12. Wells for which water-quality analyses are available... . . . . . . . . . . . 36

13. Major drainage and generalized flood-prone areas $\quad 40$

14. Tentative locations of proposed stratigraphic test holes and observation wells... . . . . . . 50

15. Tentative locations of proposed stream-flow gaging stations and surface-water data-collection sites.

16. Schematic showing generalized basin with surface mine site and proposed sites for bydrologic monitoring 
Table 1. Available measurements at low-flow, partial-record stations, and miscellaneous sites in Lauderdale County . . . . . . . . . . . . . . . . 20

2. Post-Midway geologic units underlying Lauderdale County and their bydrologic significance . . . . . . 30

3. Records of wells in Lauderdale County for which water-quality analyses are available . . . . . . . 32

4. Water-quality analyses of water from wells in Lauderdale county . . . . . . . . . . . . . . 34

5. Low-flow characteristics of some streams in Lauderdale County ...................... 41

6. Proposed stratigraphic test holes and observation wells in Lauderdale county . . . . . . . . . . 49

7. Proposed stream-flow gaging stations and surfacewater data-collection sites in Lauderdale County . . . 54

8. Sediment data collected for the Hatchie River at Rialto................ . 57

Cover Photograph

Dr. R. W. Lounsbury of

Memphis State University with hand on top of lignite bed. 
FACTORS FOR CONVERTING U.S. CUSTOMARY UNITS

TO INTERNATIONAL SYSTEM OF UNITS

The following factors may be used to convert U.S. customary units (SI). Conversion factors are rounded to four significant digits, except the one with an asterisk after the last digit which is exact.

Multiply U.S. customary units

By

To obtain SI units

Length

inch (in)

foot $(f t)$

mile (mi)

25.4 *

0.3048

1.609

millimeter ( $\mathrm{mm})$

meter (m)

kilometer $(\mathrm{km})$

Area

acre

0.4047

square mile (mi2)

2.590

square bectometer $\left(\mathrm{bm}^{2}\right)$

square kilometer $\left(\mathrm{km}^{2}\right)$

Mass

ton, short $(2,000 \mathrm{lb})$

0.9072

metric ton

Flow

cubic foot per second

$$
\text { (ft } 3 / s \text { ) }
$$

28.32

0.02832

cubic foot per second per

0.109

square mile $(\mathrm{ft} 3 / \mathrm{s}) / \mathrm{m}^{2}$

0.06309

$6.309 \times 10^{-5}$

gallons per minute (gal/min)

0.04381

liter per second (L/S)

cubic meter per second $\left(\mathrm{m}^{3} / \mathrm{s}\right)$

cubic meter per second per square kilometer $\left(\mathrm{m}^{3} / \mathrm{s}\right) / \mathrm{km}^{2}$

1 iter per second (L/s)

million gallons per day (Mgal/d)

cubic meter per second $\left(\mathrm{m}^{3} / \mathrm{s}\right)$

cubic meter per second $\left(\mathrm{m}^{3} / \mathrm{s}\right)$

$\underline{\text { Transmissivity }}$

cubic foot per day per foot

0.0929

cubic meter per day per meter $\left(\mathrm{ft}^{3} / \mathrm{d}\right) / \mathrm{ft}$

$$
\left(\mathrm{m}^{3} / \mathrm{d}\right) / \mathrm{m}
$$




\author{
APPRAISAL OF HYDROLOGIC INFORMATIUIV \\ NEEDED IN ANTICIPATION OF LIGNITE MINING \\ IN LAUDERDALE COUNTY, TENNESSEE
}

By William s. Parks

ABSTRACT

Lignite in western Tennessee occurs as lenses or beds at various stratigraphic horizons in the Coastal Plain sediments of Late Cretaceous and Tertiary age. The occurrence of this lignite has been known for many decades, but not until the energy crisis was it considered an important energy resource. In recent years, several energy companies have conducted extensive exploration programs in western Tennessee, and tremendous reserves of lignite have been found.

From available information, Lauderdale county was selected as one of the counties where strip-mining of lignite will most likely occur. Lignite in this county occurs in the Jackson and Cockfield Formations, undivided, of Tertiary age. The hydrology of the county is known only from regional studies and the collection of some site-specific data. Therefore, in anticipation of the future mining of lignite, a plan is needed for obtaining hydrologic and geologic information to adeguately define the hydrologic system before mining begins and to monitor the effects of strip-mining once it is begun.

For this planning effort, available hydrologic, geologic, land use, and associated data were located and compiled; a summary description of the surface and shallow subsurface hydrologic system was prepared; the need for additional baseline hydrologic information was outlined; and plans to monitor the effects of strip-mining were proposed. This planning approach, although limited to a county area, has transferability to other Coastal Plain areas under consideration for strip-mining of lignite.

\title{
INTRODUCTION
}

\section{Lignite in Western Tennessee}

Lignite occurs as lenses or beds at various stratigraphic horizons in the Coastal Plain sediments of western Tennessee. The principal geologic units in which lignite is at or near the surface are the McNairy Sand of Late Cretaceous age and the Wilcox Group, Claiborne Group (including the Cockfield Formation), and Jackson Formation of Tertiary age.

Figure 1 shows the principal areas where lignite is known to be relatively common. Lignite in the McNairy sand occurs in association with clay deposits east of Paris in Henry County. Lignite in the Wilcox Group may be present at many places along the outcrop belt, but is probably more common in Hardeman County where the formation is thickest and the outcrop belt is broadest. Lignite in the lower part of the Claiborne Group is present at many places, but is best known from beds encountered in mining for commercial ball clay in Henry and Weakley counties. Lignite in the Jackson and Cockfield Formations is present in the western part of western Tennessee--principally in Lake, Obion, Dyer, Lauderdale, Tipton, and shelby Counties. 


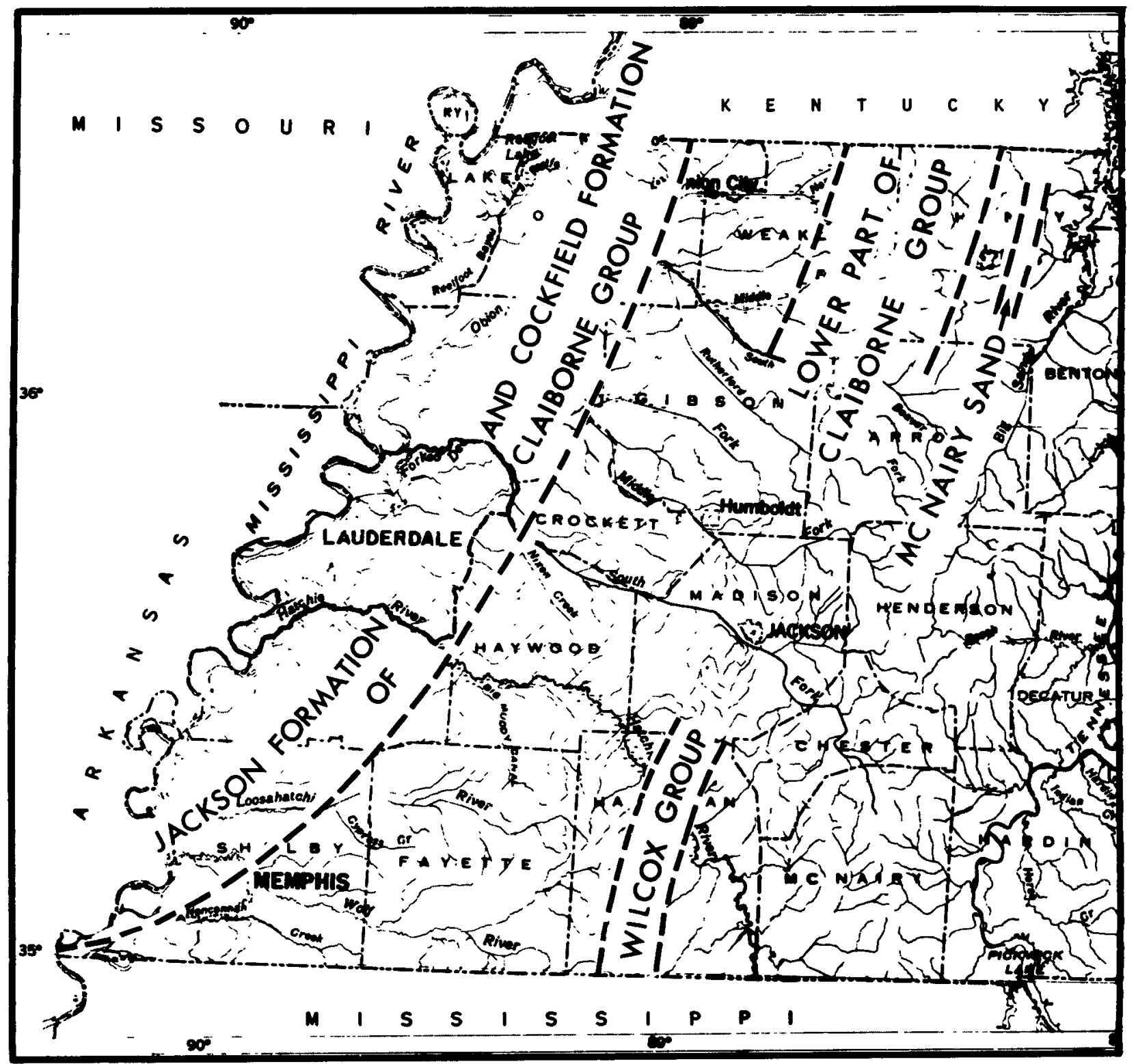

Base map by U.S. Geological Survey and Tennescee Valley Authority

EXPLANATION

Areas shown are very generalized and are those where lignite localities seem to be common on the basis of available information. They do not indicate the outcrop areas for the particular formations. See text for additional details.

Figure 1.--Principal areas in western Tennessee where lignite is known to be relatively common and location of Lauderdale County. 
The occurrence of 1 ignite in western Tennessee probably has been known since the first explorers and settlers traveled through the area. Over the years, lignite has been more or less a curiosity to the general public as evidenced by accounts of finds of "coal" or lignite published in the newspapers from time to time (Nelson, 1912, p. 157).

Geologists and other scientists also have long known about the lignite in western Tennessee. Safford (1869, p. 428-431, 498-499) in an early report on the geology of Tennessee described exposures of lignite in Shelby and Tipton Counties. Nelson (1912) in a short report on lignite and lignitic clays gave background information on lignite as compared with coal and described a reported occurrence in Henry County. Roberts and Collins (1928, p. 124-127, 146-148, 327-336) in an unpublished report on the Tertiary and Quaternary geology of western Tennessee described lignite in Shelby, Tipton, and Hardeman Counties and included analyses. Born $(1936, p .68)$ in a summary of the state's mineral resources gave a brief description of the lignite and stated that it had been reported in Lake, Obion, Dyer, Lauderdale, Tipton, and Shelby Counties. Whitlatch $(1940$, p. 67-70, 74, 92, 115, 120, $121,125,182,259,265,305,314,315)$ in a report on the clays of western Tennessee included much additional information on the occurrences of lignite in association with the clays. Parks and Lounsbury (1975, p. 49-51) in a field trip guide to the environmental geology of Memphis gave a detailed measured section which includes two lignite beds in soutbwestern Tipton county.

Lignite in western Tennessee, historically, has been considered of little or no value. Safford (1869, p. 499), Roberts and Collins (1928, p. 336), and Born (1936, p. 68) discouraged consideration of western Tennessee lignite as an important energy resource. Until recently, this thinking has remained prevalent among workers inventorying the state's mineral resources in view of the tremendous coal reserves present in eastern Tennessee. Reasons for past discouragement of thinking of lignite as an important energy resource are:

(1) a lack of demand for lignite as a fuel in view of other available fuels--wood, coal, and natural gas;

(2) the cover of loess and fluvial deposits which obscures the Upper Cretaceous and Eocene bedrock in extensive areas, making exploratory drilling necessary to determine the areal extent and thickness of the lignite;

(3) the mistaken concept based on outcrops and available bore hole records that the lignite occurs in localized deposits;

(4) the relatively low fuel value and high moisture and ash content of lignite; and

(5) the impurity of most lignites investigated along with the common mistake of reports of lignite turning out to be lignitic clays.

To some, lignite has been considered almost a nuisance (Tennessee Department of Conservation, 1977). Deposits exposed to air dry out and tend to undergo spontaneous combustion, producing a smoky, irritating fire; lignite burns are known to have occurred at several different localities in Mississippi (Williams, 1976, p. 12). Lignite bedded with commercial clay deposits has been considered overburden and has been removed and discarded 
as mine waste. In drilling for water, lignite is avoided in setting well screens because water associated with lignite imparts an unpleasant taste and color to well water.

With the advent of the energy crisis, new thinking has come about in considering the lignite of the Gulf Coastal Plain as an important future energy resource. In the past several years, energy companies have engaged in exploration programs in Texas, Louisiana, Arkansas, Mississippi, Tennessee, and Alabama.

Although specific data from these exploration programs is considered to be proprietary information, news releases, reports by the energy companies, extensive close-spaced test $d r i l l i n g$ and coring, and leasing of large acreages indicate that the energy companies have found very sizable deposits of potentially minable lignite in western Tennessee. In fact, Luppens (1978) of Phillips Coal Company, in a paper on exploration for Gulf Coastal Plain lignite deposits presented at the Second International Coal Exploration Symposium, stated that preliminary estimates of lignite reserves for Tennessee totaled 1.0 billion tons. Luppens also stated that all of these reserves are in the Wilcox and Claiborne and that typical seam thickness ranges from 2 to $9 \mathrm{ft}$. Much of Phillip's exploration program has been directed toward lignite in the Jackson and Cockfield Formations--principally in Lauderdale and Dyer Counties.

Not much published or in-file data is available on the characteristics of the "purer" lignite in western Tennessee. Luppens (1978), however, gives a "typical as-received proximate analysis" for lignite in the claiborne. These are as follows:

$\begin{array}{lcc}\text { Moisture content } & 45.41 & \text { percent } \\ \text { Ash } & 11.89 & " \\ \text { Volatile matter } & 26.56 & " \\ \text { Fixed carbon } & 16.14 & " \\ \text { Sulfur } & 0.59 & " \\ \text { Heating value } & 5379 \mathrm{Btu} / 1 \mathrm{~b}\end{array}$

Wet, the lignite is high in moisture and volatile content; dry, it is high in ash. The high volatile content makes it readily convertible into gas or liquid form. But, the high moisture content of the wet and susceptibility to spontaneous combustion of the dry present problems in transportation and storage. Western Tennessee lignite is low in sulfur, making it desirable for steam electric generating plants.

Because it is not economically feasible to transport lignite long distances, utilization of this fuel will probably be near mine operations. Possible uses include steam-electric generation, gasification, distillation of liguid hydrocarbons, and extraction of waxes (Terry and others, 1979a, p. 4).

Sites for electric generating plants on the Mississippi River have been under consideration for many years. One site investigated by TVA is at Fulton in Lauderdale County (Tennessee Valley Authority, 1952). Although it was planned to use coal barged from Illinois and western Kentucky as fuel at this plant, sizable deposits of lignite in this area would be a convienent source of an alternate fuel. 


\section{Purpose and Scope of this Project}

Outside of the Memphis area, the hydrologic system in western Tennessee is known only in general terms. The hydrology and geology are described in reports of regional scope and some site-specific studies; some ground-water and surface-water data are being collected on a continual basis as part of the state-wide hydrologic network. Nevertheless, much additional hydrologic and geologic information would be needed to adeguately define the hydrologic system of Lauderdale county in anticipation of the future strip-mining of lignite.

The purpose of this project is to plan a comprebensive study of the hydrology of Lauderdale County as related to future strip-mining of lignite. Elements of this planning effort are to:

(1) locate and compile hydrologic, geologic, land use, and associated data for use in planning the study;

(2) prepare a description of the surface and shallow subsurface hydrologic system in Lauderdale county in terms of what is presently known;

(3) research background information concerning lignite and coal hydrology and other areas undergoing strip-mining;

(4) consider the impact of strip-mining lignite on the hydrologic system as presently known for Lauderdale County;

(5) ascertain what baseline hydrologic and geologic information are needed to adequately define the hydrologic system before mining begins; and

(6) propose a plan for the collection of hydrologic data to monitor the effects of strip-mining once it is begun.

Although this project is limited to a county area, the planning approach has transferability to other areas where strip-mining of lignite is under consideration. The project is regional in scope in that the environmental concerns of interstate streams and aquifers are involved and the planned study, if undertaken, would provide important information needed in refining concepts of the hydrologic system in this part of the Mississippi embayment.

The information provided in this report would be useful to those Federal and State agencies, energy companies, and private consultants involved in conducting environmental studies or preparing environmental impact statements. In addition, this report includes a summary of available information about the hydrology and geology of Lauderdale County which will be useful to those concerned with other water resources problems.

In preparing this report consideration was given to the need for geologic and hydrologic information to satisfy the minimum requirements for surface-mining permit applications as given by the U.S. Department of the Interior, office of Surface Mining, Reclamation and Enforcement (1979, p. 15354-15357). 


\section{Location and Size of Project Area}

Lauderdale County is in the western most tier of counties in western Tennessee about midway between the Mississippi and Kentucky state lines. Ripley, the county seat, is at about lat $35^{\circ} 44^{\prime} 45^{\prime \prime}$ N., long $89^{\circ} 31^{\prime} 50^{\prime \prime} \mathrm{W}$. Figure 1 shows the location of Lauderdale County.

The county covers an area of $477 \mathrm{mi}^{2}$ and is very irregular in shape. It is bounded on the north by Dyer, on the east by Crockett and Haywood, on the south by Tipton counties in Tennessee and on the west by Mississippi county in Arkansas. Natural features that form part of the boundaries are the Mississippi River on the west, the Obion and Forked Deer Rivers on the northwest, the South Fork Forked Deer River on the northeast, and the Hatchie River on the south.

\section{Population and Land Use}

The population of Lauderdale county, according to the 1970 "Census of Population," was 20,271 of which 15,477 or 76.4 percent was considered to be rural. The only area considered to be urban is the incorporated town of Ripley (population 4,794). Other incorporated towns are Halls $(2,323)$, Henning (605), and Gates (523). These towns are along U.S. Highway 51 and the Illinois Central Railroad, which cross the central part of the county in a northeast-southwest direction.

The area of the county, according to the 1974 "Census of Agriculture," consists of approximately 305,408 acres of which 204,788 acres or 67.1 percent are in farm land. Farms total 844 and average about 243 acres in size. A decrease in number and increase in size of farms and an increase in population of towns follows the population trend of movement from rural to urban areas or towns.

Aside from the land in the four incorporated towns, other areas designated for special land use which may need consideration in anticipation of future strip-mining of lignite are: (1) Fort Pillow State Historic Area, (2) Fort Pillow State Prison Farm, (3) Hatchie State Scenic River, and

(4) Anderson-Tully Wildlife Management Areas. These special land-use areas comprise an estimated 40,729 acres or about 13.3 percent of the county area. Figure 2 shows their location and relative size.

Fort Pillow State Historic Area consists of 1,650 acres in the southwestern part of the county. This part was established to preserve the earthworks, artifacts, and general area surrounding the site of Fort pillow-a Civil war fort. The management of this park is under the Tennessee Department of Conservation, Division of Parks and Recreation. In recent years, a park headquarters, museum, and other improvements have been built, and in 1977 the park was opened for use by the public. On May 30, 1974, the site of Fort Pillow was designated a "National Historic Landmark" by the U.S. Department of Interior.

Fort Pillow State Prison Farm consists of 5,779 acres in the southwestern part of the county. This farm is worked by the inmates of Fort pillow state Prison and provides food for the prison population and 


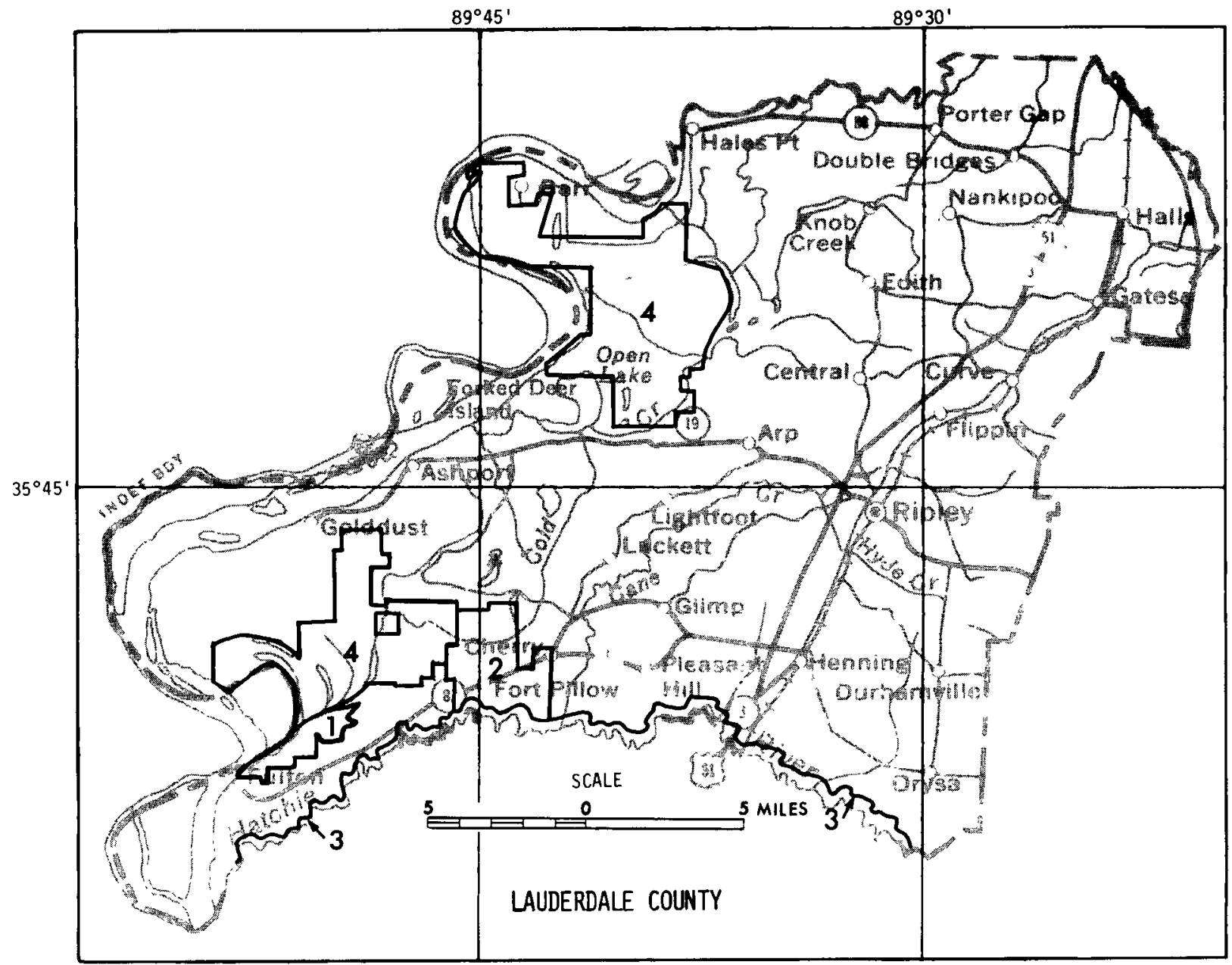

EXPLANATION

1 - Fort Pillow State Historic Area

2 - Fort Pillow State Prison Farm

3- Hatchie State Scenic River

4 - Anderson-Tulley Wildlife Management Area(s)

Figure 2.--Location and relative size of special land-use areas. 
financial support for the institution. The management of the farm is under the Tennessee Department of Corrections, Division of Agri-Industry. In addition to the prison facility, the farm has many buildings and other improvements related to the farming activity.

Hatchie State Scenic River established in 1969 by the Tennessee Legislature will consist of an estimated 3,300 acres in the southern part of the county, if the maximum easement of no more than 1,000 ft from the center of the river on each side is acquired. This easement will include the Hatchie River channel and a large part of the flood plain. The Hatchie River is one of the few remaining streams in Tennessee which is relatively unchanged by man's activities. Although many of the tributaries were dredged during 1917-26 (Speer and others, 1965, p. H8), the main channel and flood plain have not been subject to channelization and agricultural development. The Tennessee State Scenic Rivers Act of 1968 (Tennessee Code Annotated 11-1400) specifies certain restrictions on the use of scenic river areas, including mining and pollution from mining. Various aspects related to the future management of the Hatchie State Scenic River are being investigated by the Hatchie State Scenic River Task Force under the Scenic Rivers Program of the Tennessee Department of Conservation.

Anderson-Tully Wildlife Management Area(s) consist of two tracts of land comprising an estimated 30,000 acres in the western part of the county. These areas--approximately 18,000 acres in the northern tract in the vicinity of Open Lake and 12,000 acres in the southern tract near Fort Pillow State Historic Area--are owned by Anderson-Tully Company, a lumber concern. These acreages represent the largest single tracts of delta bottom-land hardwood timber left in Tennessee (Frank zerfoss, oral commun., 1979). Presently, the Anderson-Tully property is under lease to the Tennessee Wildlife Resources Agency for the purpose of wildlife management.

\section{AVAILABILITY OF HYDROLOGIC INFORMATION}

\section{Previous Investigations}

Glenn (1906, p. 9I-96) and Wells (1933, p. 210-219) in reports describing the ground-water resources in western Tennessee on a county-bycounty basis gave general information about the stratigraphy and the ground-water supplies in Lauderdale County. Although the stratigraphy is now out-of date insofar as nomenclature is concerned, these reports provide historical data about early ground-water supplies and some information about the geology. Lanphere (1955) described the geologic source and chemical quality of public ground-water supplies in western Tennessee. This report (p. 38-39, 40, 57-58) includes details concerning the water-supply systems at Halls, Henning, and Ripley. Strausberg and Schreurs (1958, pl. 1, 2, 4; tables 4,5 ) in an unpublished report on the ground-water resources of the Mississippi Valley of Tennessee included the locations of some wells in the Mississippi alluvial deposits in Lauderdale county and some data on water levels and quality of water.

Milhous (1959) compiled driller's logs and sample descriptions for Tennessee by counties. He gave logs for three early oil-test wells in the county (p. 233-239). Krinitzsky and wire (1964) described the ground water in the alluvium of the Lower Mississippi Valley. They presented contour 
maps of the Tertiary surface and piezometric-surface maps for the Mississippi alluvial deposits. Moore $(1965, \mathrm{pl} .1-8, \mathrm{fig} .4)$ in a report on the geology and hydrology of the Claiborne Group in western Tennessee included structure-contour maps, geophysical cross-sections, and a fence diagram along with maps of the apparent and potential coefficient of transmissibility, the down-dip changes in chemical quality of water, and the piezometric surface in the "500-foot" sand. These illustrations provide some general information about the Claiborne aquifers in Lauderdale County.

Speer and others (1965, table 2) in a report on the low-flow characteristics of streams in the Mississippi embayment in Tennessee, Kentucky and Illinois gave data concerning South Fork Forked Deer River at Chestnut Bluff, Cold Creek near Arp, Cane Creek at Ripley, and Cane Creek near Cherry. The Tennessee Department of Public Health (1964-65) published a ground-water survey of western Tennessee. Their report (table 18) includes a summary of the water-supply system at Ripley and gives chemical analyses and radiological data of composite raw water sampled in 1964-65. Moore and Brown (1969) detailed information on the stratigraphy and ground-water resource gained by a 3,183-ft test hole drilled into the Paleozoic rock on property within Fort Pillow State Historic Area. This report introduces some new nomenclature for the subsurface geologic units of western Tennessee and re-evaluates certain interpretations presented by Moore in his 1965 report.

\section{Topographic and Geologic Maps}

Lauderdale County is covered by 7.5-minute (scale $1: 24,000$ ) topographic quadrangles prepared and published by the Geological Survey. Figure 3 is part of the "Index to Topographic Maps of Tennessee", dated May 1978. The county is included on all or part of 20 quadrangles, as follows:

$\begin{array}{llll}\text { Armorel } & 1972 & \text { Chestnut Bluff } & 1952 \\ \text { Chic } & 1972 & \text { Osceola } & 1972 \\ \text { Knob Creek } & 1972 & \text { Golddust } & 1972 \\ \text { Fowlkes } & 1972 & \text { Ft Pillow } & 1972 \\ \text { Bonicord } & 1952 & \text { Ripley South } & 1972 \\ \text { Luxora } & 1972 & \text { Durhamville } & 1964 \\ \text { Rosa } & 1972 & \text { Nodena } & 1972 \\ \text { Open Lake } & 1972 & \text { Gilt Edge } & 1972 \\ \text { Ripley North } & 1972 & \text { Gift } & 1972 \\ \text { Gates } & 1952 & \text { Turnpike } & 1964\end{array}$

Most of the county is also included on all or part of five 15-minute (scale $1: 62,500$ ) topographic quadrangles as follows: 


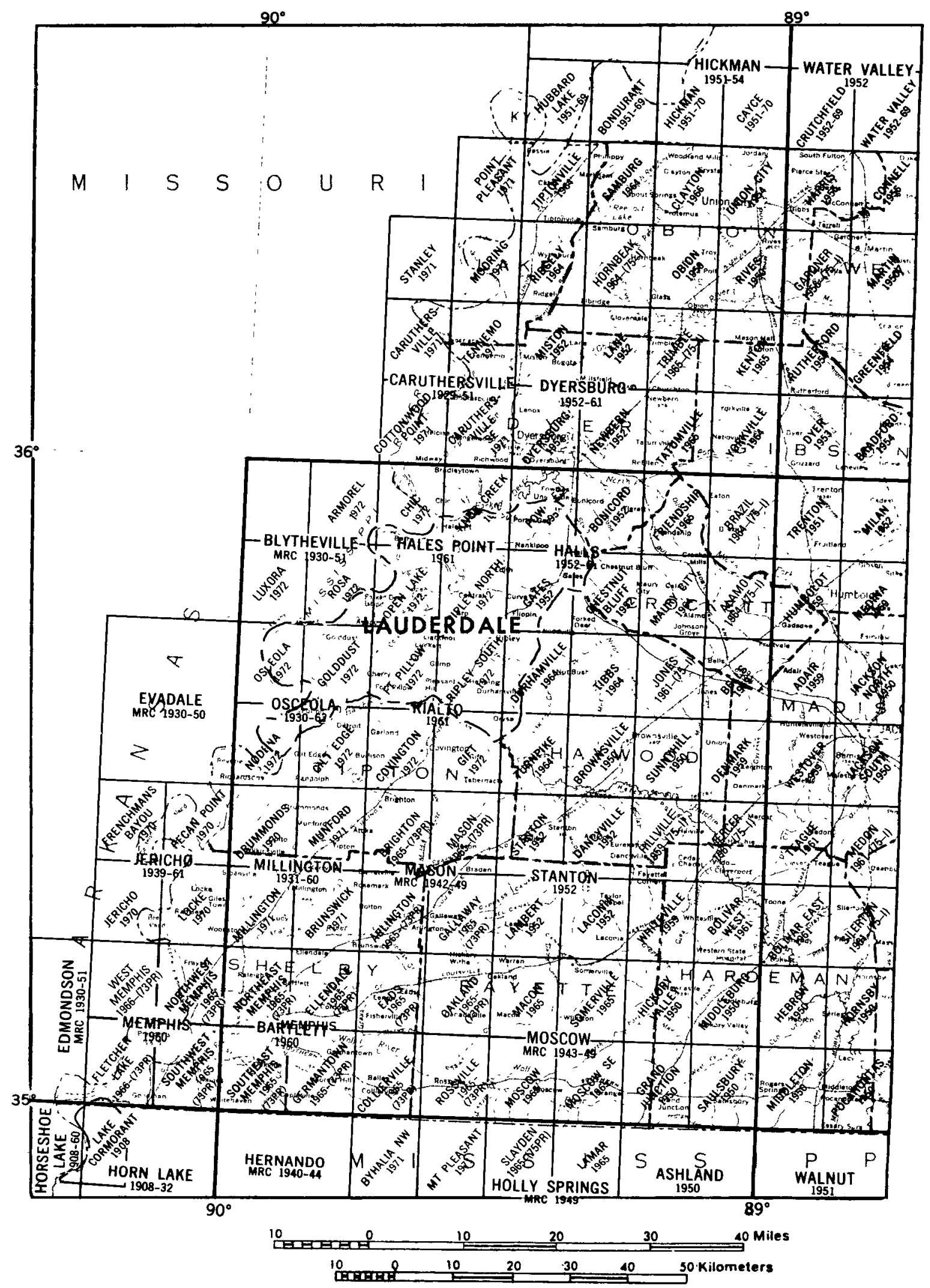

Figure 3.--Topographic quadrangles available (modified from U.S. Geological Survey "Index to Topographic maps of Tennessee," May 1978). 


$\begin{array}{llll}\text { Blytheville } & 1930-51 & \text { Osceola } & 1930-63 \\ \text { Hales Point } & 1961 & \text { Rialto } & 1961\end{array}$

Halls 1952-61

Detailed 15-minute geologic quadrangles are available for most of the Mississippi Alluvial Plain in Lauderdale County. These maps by Saucier and others (1964-78) were prepared and published by the U.S. Army Engineer Water-ways Experiment Station as a part of a geological investigation of the St. Francis River basin. Quadrangles including areas in the county are: (1) Blytheville, Ark.-Mo.-Tenn.; (2) Hales Point, Tenn.-Ark.; (3) Osceola, Ark.-Tenn.; and (4) Rialto, Tenn. The Halls, Tenn. quadrangle, which includes a small part of the Alluvial plain, was not published as a part of the investigation.

No detailed geologic maps are available for the upland areas of Lauderdale County. The latest geologic map which covers the county is the "Geologic Map of Tennessee" (scale 1:250,000) by Hardeman and others (1966), published in four sheets. The west sheet for western Tennessee provides a very generalized geologic map of the county area.

\section{Ground-Water Data}

Only very general information and some site-specific data are available concerning the ground-water hydrology of Lauderdale County. Much of this information was collected as a result of regional studies of the principal aquifers and inventories of water supplies. Except for water-well records and water-use data being collected by the Tennessee Division of water Resources (TDWR), little specific information regarding the ground-water resource has been collected over the past decade.

Well Records

The Geological Survey files contain schedules for about 50 wells in Lauderdale county drilled between 1929 and 1965. Most of these wells were inventoried in the late 1950's and early 1960's. Since 1963, however, records of approximately 600 wells have been submitted to the TDWR by water-well contractors. The locations of these wells have been provided by the drillers to TDWR on county maps (scale 1:125,000). About 20 percent of these records include a log of the formations penetrated. Land-surface altitudes and aquifer identifications are not indicated on most of these records.

Experience in working with driller's records for other areas in western Tennessee has shown that, although the well data is fair to good, the locations and formation logs are mostly fair to poor. Experience also has shown that many more wells probably exist which have not been inventoried, and the records for these wells would have to be obtained from the drillers or land owners, if available.

Of the 600 records in the TDWR files 49 percent are for wells less than $100 \mathrm{ft}$ deep and 91 percent are for wells less than $200 \mathrm{ft}$ deep (C. $R$. Lanphere, oral commun., 1979) Theșe wells are mostly privately owned domestic and farm wells. 
The Geological Survey files contain geophysical logs for 15 wells drilled in Lauderdale county. Three are for oil-test wells, one is for the Fort Pillow test well, three are for water-supply wells at Fort Pillow state Prison Farm and the town of Ripley, and eight are for test holes drilled by Phillips Coal Company on the Fort Pillow State Prison Farm in conjunction with lignite exploration. The quality of these logs, which include both gamma ray and electric, is excellent to fair depending on the logging instrument used to make them. Figure 4 shows the location of wells and test holes for which geophysical logs are available.

The logs for the Fort pillow test well and one of the oil-test wells provide important stratigraphic information about the geologic sequence above the Paleozoic rocks. The logs at Ripley, Fort Pillow state Farm, and the other two oil-test wells (only up-hole section logged) provide some site-specific information about the geology and ground-water resource.

The logs made of the Phillips test holes at Fort Pillow state Farm in conjunction with lignite exploration showed that the electric and gamma-ray logs made with the available Geological Survey logging instrument are inadequate to recognize 1 ignite beds in the absence of other information. The gamma-gamma log used by phillips, supplemented with resistance and gamma-ray logs, is the primary tool needed for this type of work. The gamma-gamma log indicates relative bulk densities, which is important in the recognition of lignite beds.

Water Levels

Except for miscellaneous measurements made in wells in the Mississippi alluvial deposits and the Memphis Sand for regional studies, the only water-level information collected by the Geological survey for Lauderdale county is for the Fort pillow test well.

This well, located in the Fort Pillow State Historic Area, is screened in the Memphis Sand at a depth of 869 to $879 \mathrm{ft}$. An automatic recorder was installed on this well in April 1966, and water levels have been monitored since that time. For alternate periods of time, both analog and digital recorders have been used on this well; it is now equipped with a digital recorder.

Problems associated with the different kinds of recorders, the depth of the water level which approaches $200 \mathrm{ft}$ below land surface, and the remoteness of this well for servicing has resulted in only fair quality records. Periods of lost record are relatively common inasmuch as time between servicing has been from 4 to 6 weeks.

Water levels for the Fort Pillow observation well are summarized in the Geological Survey's "Water Supply Paper" series and the annual reports "Water Resources Data for Tennessee".

\section{Quality of water}

The Geological Survey files contain chemical analyses of water from 20 wells in Lauderdale county; these analyses are given in table 4 later in 


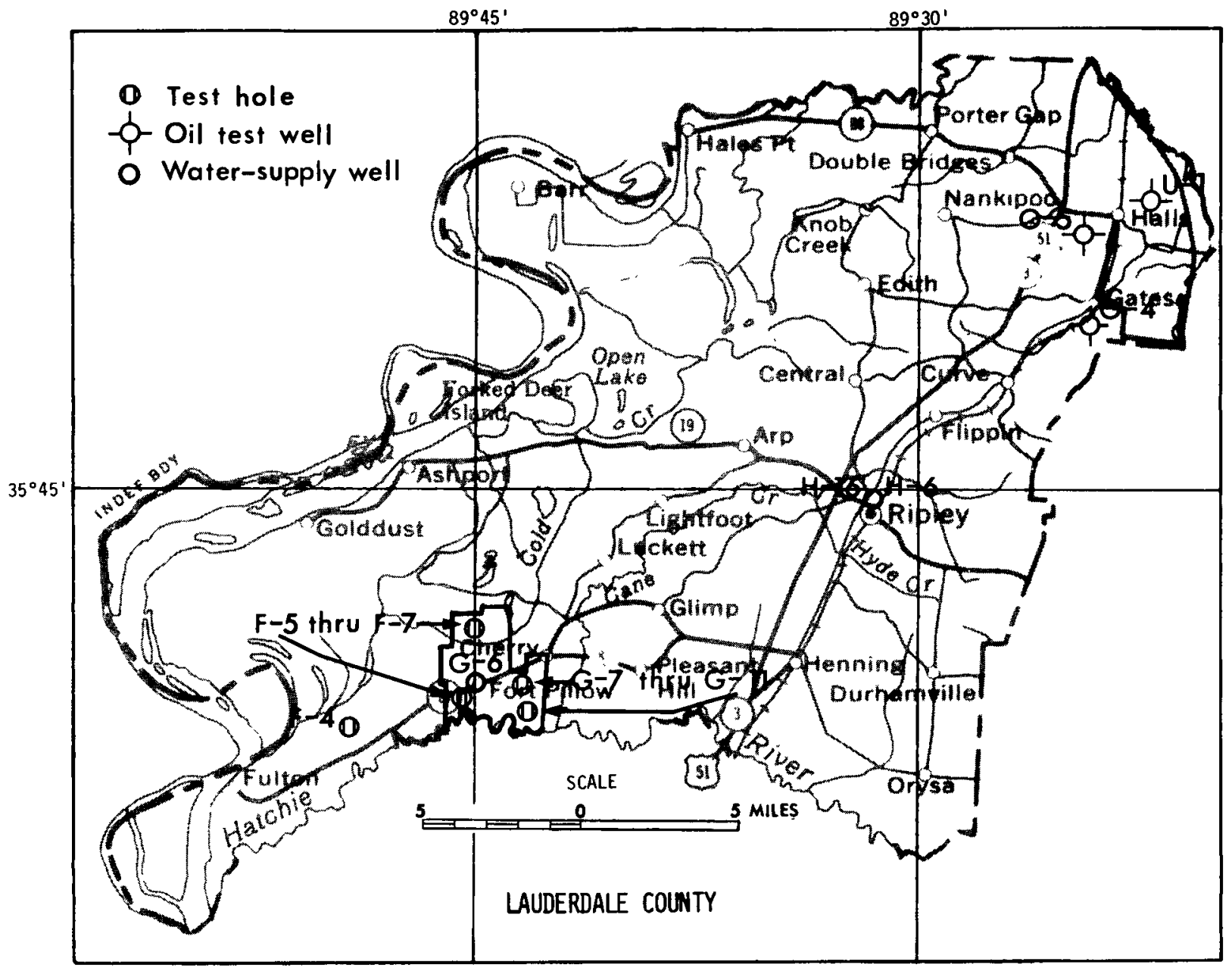

\section{EXPLANATION}

F-4 Stratigraphic test hole at Fort Pillow State Historic Park F-5 thru F-7 Lignite test holes at Fort Pillow State Prison Farm G-6 Water-supply well at Fort Pillow State Prison Farm G-7 thru G-11 Lignite test holes at Fort Pillow State Prison Farm H-6 thru H-16 Water-supply wells at town of Ripley 0-4 0 il test well--Raymond Gear, Lee No. 1 0-5 0il test wel1---Pure 0il Co., R. E. Craddock No. 1 U-1 0il test well--Raymond Gear, Dyer Bros. No. 1

Well numbers are USGS local well-numbering system for Tennessee and are generally prefixed "Ld:" for Lauderdale County.

Figure 4.--Wells and test holes for which geophysical logs are available. 
this report. Six analyses are for wells in the Mississippi alluvial deposits, two in the fluvial deposits, four in the Jackson and Cockfield Formations, and eight in the Memphis Sand. The wells were sampled between 1929 and 1965, but most were sampled during the 1950's. The data for the Memphis Sand includes analyses of water from deep water-supply wells at Ripley, Henning, Fort Pillow State Prison Farm, and the Fort Pillow test well.

As mentioned in "Previous Investigations", a publication by the Tennessee Department of Public Health (1964-65) includes chemical analyses and radiological data of composite raw water from the supply system at Ripley. These data are for samples taken monthly over a period of 12 months in $1964-65$.

Pumping Tests

Two short-period pumping tests have been conducted in Lauderdale County--one on a deep well (755 ft deep) at Ripley in the Memphis Sand and the other using two shallow wells $(239$ and $241 \mathrm{ft}$ deep) at the U.S. Military Reservation near Halls in the Jackson and Cockfield Formations. Values for transmissibility were determined from these tests; a value for storage coefficient was determined for the test at the U.S. Military Reservation at Halls. This is the only specific information available as to the hydrologic characteristics of the aquifers in the county.

\section{Surface-water Data}

Information is available on the stream-flow characteristics of the major streams that receive drainage from Lauderdale County. Continuousrecord gaging stations are being operated on the South Fork Forked Deer River and the Hatchie River and partial-record gaging stations are being operated on the Mississippi River at two sites. Not much information is available on the stream-flow characteristics of the tributary streams that drain the county. A continuous-record gaging station was once operated on Cane Creek, and infrequent discharge measurements have been made from time to time at miscellaneous sites. Figure 5 shows the location of existing and discontinued stream-flow gaging stations and miscellaneous data-collection sites. Other surface-water or related data available for the county includes flood-prone area maps, sediment data for the Hatchie River, and daily rainfall data at Ripley.

\section{Continuous-Record Gaging Stations}

Continuous-record gaging stations have been operated by the Geological Survey on the South Fork Forked Deer River at Chestnut Bluff (1929 to 1957) and on Cane Creek at Ripley (1957 to 1962). Daily, monthly, and yearly discharge have been published for each water year in the survey's "Water Supply Papers" and "Surface Water Records of Tennessee." The description and summary for these stations at the time they were discontinued are as follows: 


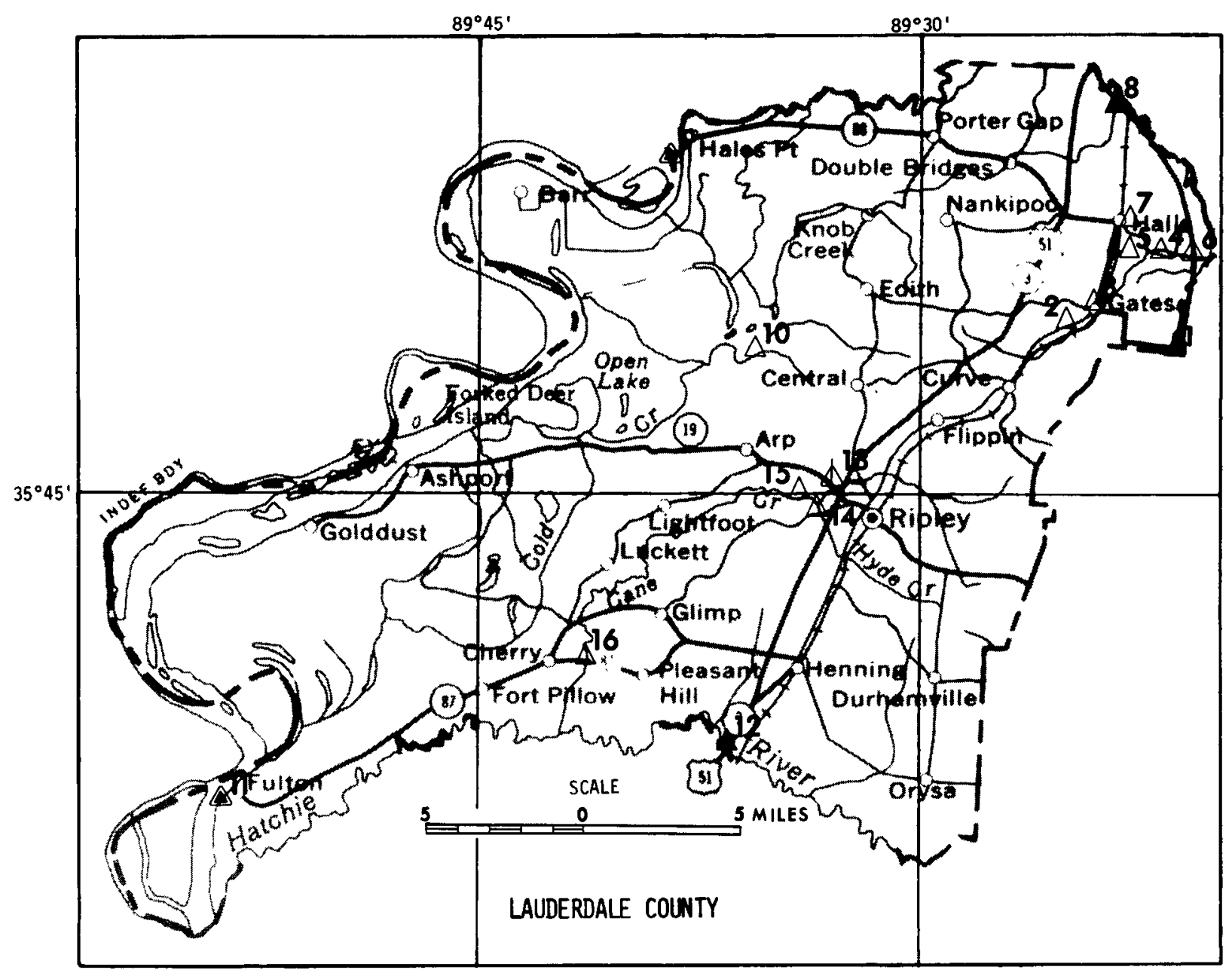

EXPLANATION

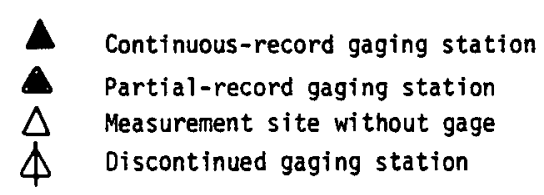

\begin{tabular}{cl}
$\begin{array}{c}\text { Map } \\
\text { number }\end{array}$ & $\begin{array}{l}\text { Station } \\
\text { number }\end{array}$ \\
\hline 1 & 07027800 \\
2 & 07027970 \\
3 & 07027971 \\
4 & 07027980 \\
5 & 07027990 \\
6 & 07028000 \\
7 & 07028010 \\
8 & 07028100 \\
9 & 07029140 \\
10 & 07029200 \\
11 & 07029220 \\
12 & 07030050 \\
13 & 07030100 \\
14 & 07030110 \\
15 & 07030120 \\
16 & 07030140
\end{tabular}

\section{Location}

South Fork Forked Deer River near Gates

Tisdale Creek at Gates (south)

Tisdale Creek at Gates (east)

Halls Creek near Chestnut Bluff

Halls Creek tributary near $\mathrm{Ha}$ l Is

South Fork Forked Deer River at Chestnut Bluff

Drainage ditch at Halls

South Fork Forked Deer River near Halls

Mississippi River at mouth of Obion River

Cold Creek near Arp

Mississippi River at Fulton

Hatchie River at Rialto

Cane Creek at Ripley

Hyde Creek at Ripley

Cane Creek below Ripley

Cane Creek near Cherry 
07028000 South Fork Forked Deer River at Chestnut Bluff, Tenn.

Location.-- Lat $35^{\circ} 51^{\prime} 43^{\prime \prime}$, long $89^{\circ} 20^{\prime} 52^{\prime \prime}$, on left bank $20 \mathrm{ft}$ downstream from county highway bridge, $0.8 \mathrm{mile}$ west of Chestnut Bluff, Crockett County, 1.1 miles upstream from Halls Creek, 1.2 miles downstream from Black Creek, 2.9 miles east of Halls, 3.1 miles downstream from state Highway 88 , and 16 miles upstream from confluence with North Fork. Records include flow of Halls Creek.

Drainage area.--1,100 $\mathrm{sq} \mathrm{mi}$, approximately, includes that of Halls creek.

Records available.--July 1929 to September 1957 (after September 1949, flow of Halls Creek included), discont inued.

Gage. Water-stage recorder. Datum of gage is $256.88 \mathrm{ft}$ (revised), unadjusted, above mean sea level. Prior to July 20,1939, staff gage at same site and datum.

Average discharge.--28 years, 1,410 cfs.

Extremes.--Maximum discharge during year, 14,200 cfs Feb. 1 (gage height, $19.90 \mathrm{ft}$ ); minimum, $147 \mathrm{cfs}$ Oct. 1 (gage height, $6.55 \mathrm{ft}$ ).

1929-57: Maximum discharge, 45,000 cfs Jan. 22, 1935 (gage height, $22.3 \mathrm{ft}$, from floodmarks), from rating curve extended above 21,000 cfs; minimum observed, $102 \mathrm{cfs}$ Aug. 31, Sept. 1, 1936; minimum gage height observed, $3.2 \mathrm{ft}$ Aug. 5-13, 1930.

Remarks.--Records fair except those for periods of no gage-height record or shifting control, which are poor.

Revisions (water years).--WSP. 1211: 1930, 1934, 1936, 1950. WSP 1281: $1935,1937,1946$ (M), 1950 (M).

\section{Cane Creek at Ripley, Tenn.}

Location.--Lat $35^{\circ} 45^{\prime} 22^{\prime \prime}$, long $89^{\circ} 33^{\prime} 05^{\prime \prime}$, on upstream side of right bank pier of bridge on State Highway 19, 1.3 miles upstream from Hyde Creek, and 1.5 miles northwest of Ripley, Lauderdale County.

Drainage area. $--30 \mathrm{sq} \mathrm{mi}$, approximately.

Records available.--October 1957 to September 1962 (discontinued).

Gage.--Water-stage recorder. Datum of gage is $309.78 \mathrm{ft}$ above mean sea level, from preliminary field elevations by U. S. Coast and Geodetic Survey. Prior to Nov. 14, 1957, staff gage at same site and datum.

Average discharge. --5 years, 52.3 cfs.

Extremes.--Maximum discharge during year, 3,350 cfs Feb. 27 (gage height, $14.52 \mathrm{ft}$ ) from rating curve extended above $1,200 \mathrm{cfs}$; minimu, $0.2 \mathrm{cfs}$ Sept. 13; minimum gage height, $2.41 \mathrm{ft}$ Aug. 23.

1957-62: Maximum discharge, that of Feb. 27, 1962; minimum, 0.1 cfs May 19, 24-26, Sept. 25, 1959; minimum gage height, $1.60 \mathrm{ft}$ Sept. 7, 1958. 
Remarks.--Records poor. Natural flow affected by upstream discharge of Ripley sewage effluent.

The U.S. Army Corps of Engineers presently maintains continuous-record gaging stations on the South Fork Forked Deer River near Halls (1939 to date), the South Fork Forked Deer River near Gates (1969 to date), and the Hatchie River at Rialto (1939 to date). Daily stages and computed discharges have been published in "Stages and Discharges of the Mississippi River and Its outlets and Tributaries," and "Stages and Discharges of the Mississippi River and Tributaries in the Memphis District" by the Corps of Engineers. The description and summary for these stations from the 1976 issue of the latter report are as follows:

\section{South Fork of Forked Deer River near Halls, Tenn.}

Location.--Lat $35^{\circ} 55^{\prime} 45^{\prime \prime}$, long 89 $23^{\prime} 2^{\prime \prime}$. Mile 1l.3, railroad bridge about four miles north of Halls, the mouth of South Fork is 20.6 miles upstream from mouth of Forked Deer River, Forked Deer River is a tributary entering Obion River at mile 3.0.

Gage.--Automatic recorder on bridge.

General information.--Drainage area, 1,014 square miles. Bankfull stage, 8.5 feet. Discharge is affected by backwater during high Mississippi River stage.

Record available.--Stage, Jan. 19, 1939, to date. Discharge, 1939 to date. Computed daily, 1947 to date.

Extremes.--Highest, 15.21 feet on Mar. 16, 1975. Lowest, minus 3.61 feet on Sep. 5, 1975. Maximum, 34,320 cfs computed on Mar. 16, 1975. Minimum, 123 cfs observed on Oct. 18, 1956 (stage 0.68).

Daily eight a.m. stage in feet Gage zero, 259.09 feet, M.S.L. (1929 adj.)

07027800 South Fork of Forked Deer River near Gates (East), Tenn.

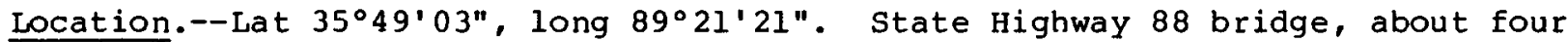
miles east of Gates and one mile west of Gillilands, on down stream side of bridge.

Gage.--Automatic recorder on bridge.

Records available.--Stage and daily discharge, Jan. 1, 1969 to date.

Extremes.--Highest, 21.19 feet on Mar. 16, 1975. Lowest, 7.25 feet on Jul. 2, 1969. Maximum, 35,328 cfs computed on Mar. 16, 1975. Minimum, 138 cfs computed for Dec. 9, 1971 .

Daily eight a.m. stage in feet Gage zero, 259.50 feet, M.S.L. (1929 adj.) 
07030050 Hatchie River at Rialto, Tenn.

Location.--Lat $35^{\circ} 38^{\prime} 14^{\prime \prime}$, long $89^{\circ} 36^{\prime} 14^{\prime \prime}$. U.S. Highway 51 bridge at mile 34.0. The mouth of Hatchie River is 773.3 miles upstream on the

Mississippi River from head of passes.

Gage.--Automatic Recorder on bridge.

General information.--Drainage area, 2,308 square miles. Bankfull stage is 12 feet. Discharge is affected by backwater during high Mississippi River stages.

Records available.--Stage, Jan. 7, 1939, to date (high water stages, 1932 to date). Prior to 1950, gage was located one mile upstream. Zero of gage prior to 1953 was minus 0.30 foot, M.S.L. Computed daily discharge, 1939 to date.

Extremes.--Highest, 23.54 feet on Jan. 22, 23, and 25, 1937. Lowest, minus 0.06 foot on Sept. 28, 1956. Maximum, 55,700 cfs computed for Jun. 13, 1946 (stage, 22.0). Discharge not determined for record high stage. Minimum, $180 \mathrm{cfs}$ computed for Jul. 9, 10, Nov. 3 and 4, 1943 (stage, 0.0).

Daily eight a.m. stage in feet Gage zero, 239.81 feet, M.S.L. (1929 adj.)

\section{Partial-Record Gaging Stations}

The Corps of Engineers presently maintains two partial-record gaging stations on the Mississippi River in Lauderdale County--one at the mouth of the Obion River (1928 to date) and the other at Fulton (1879 to date). Daily stage has been published in "Stages of the Mississippi River and of Its Principal Tributaries," "Stages and Discharges of the Mississippi River and Its Outlets and Tributaries," and "Stages and Discharges of the Mississippi River and Tributaries in the Memphis District" by the Corps of Engineers. The description and summary for these stations from the 1976 issue of the latter report are as follows:

07029140 Mississippi River H. W. Gage 158 at Mouth of Obion River, Tenn. Location.--Lat $35^{\circ} 54^{\prime} 14^{\prime \prime}$, long $89^{\circ} 38^{\prime} 24^{\prime \prime}$. High water gage at mile 819.1 . Gage.--Staff type in several sections.

General information.--Drainage area (revised), 924,000 square miles. The drainage area in the Great Divide Basin in southern Wyoming, approximately 4,000 square miles, is no longer included. Average low water plane, 4.6 feet on gage.

Records available.--Stage, July 1928 to date. Prior to Nov. 23, 1939, high stages only, from site one mile upstream.

Extremes.--Highest, 52.45 feet on Feb. 8, 1937. Lowest, 0.3 foot on Jan. 23, 1956. 
Daily elgnt a.m. stage in feet $\operatorname{adj.)}$

07029220 Mississippi River at Fulton, Tenn.

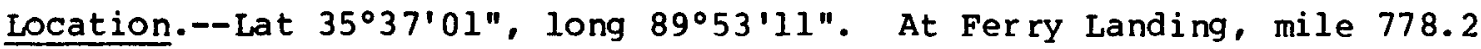

Gage.--Staff type in several sections.

General information.--Drainage area (revised), 924,300 square miles. The drainage area in the Great Divide Basin in southern Wyoming, approximately 4,000 square miles, is no longer included. Bankfull stage, 34 feet. Average low water plane, minus 1.4 feet on gage.

Records available.--Stage, Oct. 28, 1879, to date. Discharge, 1879 intermittently to 1893.

Extremes.--Highest, 47.25 feet on Feb. 9, 1937. Lowest, minus 7.70 feet on Jan. 2, 1964 .

Daily eight a.m. stage in feet Gage zero, 208.61 feet, M.S.L. (1929-58 adj.)

Low-Flow and Miscellaneous Sites

Through the years, discharge measurements or observations of no flow have been made at several low-flow, partial-record stations, and miscellaneous sites on the streams that drain Lauderdale county. These data, which are scattered through many of the Survey's "Water-Supply Papers," are given in table 1 for accessibility.

\section{Flood-Prone Area Maps}

Flood-prone areas in Lauderdale county are shown on maps prepared and distributed by the Geological survey under its reconnaissance flood mapping program. These flood-prone areas are delineated on topographic guadrangle base maps--some on the 15-minute and others on the 7.5 minute series. The county is included on all or part of the eight maps listed below. The date following the map name is the year of compilation of the flood information and the year in parenthesis is the edition of the base map.

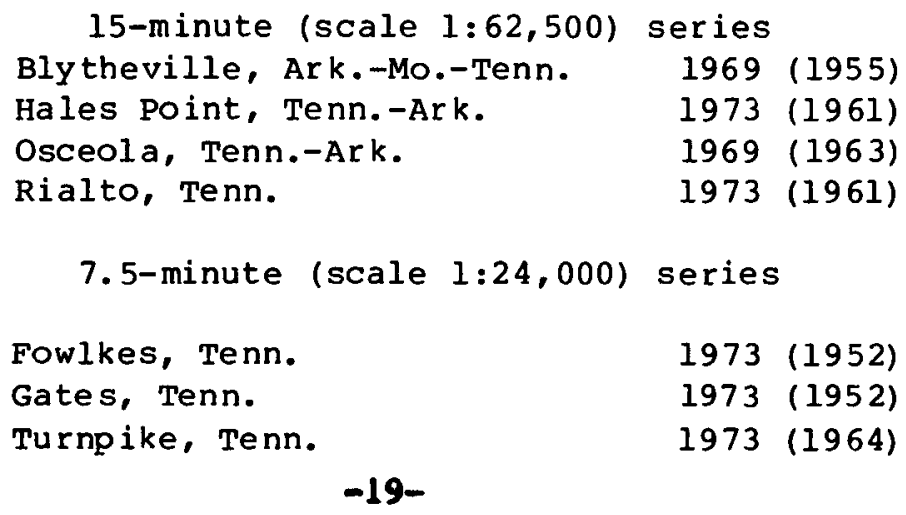


Table 1.--Available measurements at low-flow, partial-record stations and miscellaneous sites in Lauderdale County

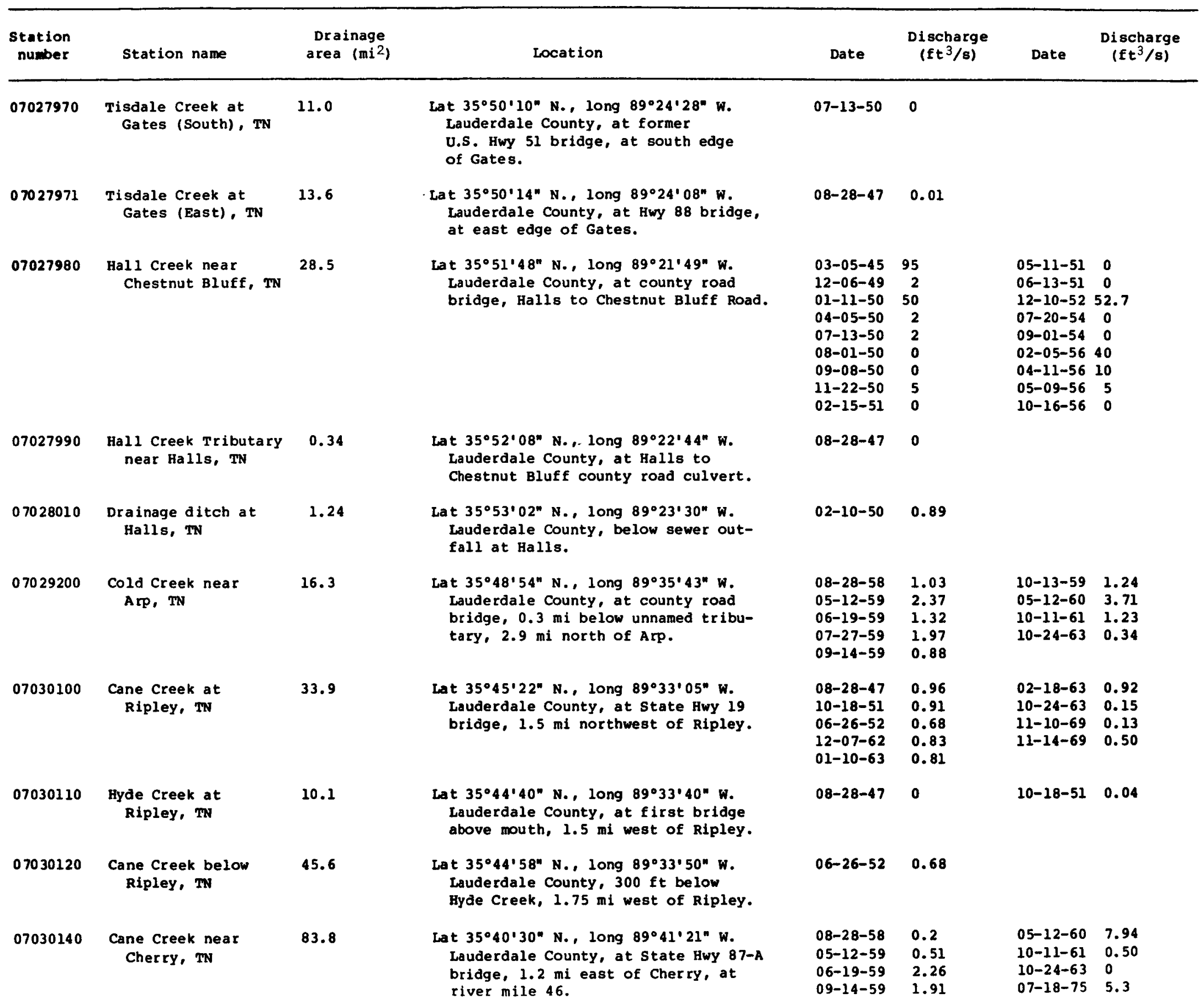


The flood-prone areas were delineated on the basis of readily available information. Criteria for the selection of flood-prone areas on these maps were: (1) urban areas where upstream drainage area exceeds 25 square miles, and (2) rural areas where upstream drainage exceeds 100 square miles. The flood-prone areas of the small tributaries were not delineated. The maps indicate only the areas that may be occasionally flooded, and provides no information on the frequency, depth, duration, and other details of flooding.

\section{Sediment Data}

Sediment data were collected by the Geological survey in February, March, August, and September 1977 and in May 1978 at the site of the Corps of Engineers gaging station on the Hatchie River at Rialto. This work was conducted in conjunction with a cooperative study of sediment transport in the Hatchie River basin between the Survey and the Scenic Rivers Program, Tennessee Department of Conservation. Sediment data for the Hatchie River at Rialto is given in table 8 of this report.

\section{Rainfall Data}

Rainfall data are available for Lauderdale county and surrounding areas from weather stations maintained by the National Oceanic and Atmospheric Administration (NOAA) at Ripley, Dyersburg, Brownsville, and Covington in Tennessee and at Blytheville and Keiser in Arkansas. Figure 6 shows the general location of these stations. Most of these stations collect only daily precipitation and daily extremes of temperature. Precipitation is recorded at the stations at Dyersburg and Brownsville; other detailed meteorological data are collected at Dyersburg; data on evaporation and soil temperature are collected at Keiser. Data from these weather-stations are published in NOAA's monthly "Climatological Data" for Tennessee.

\section{DESCRI PTION OF HYDROLOGIC SYSTEM}

\section{Geomorphic and Geologic Setting}

Lauderdale county is situated in two major geomorphic (physiographic) subdivisions. The eastern three-quarters of the county is in the East Gulf Coastal Plain section and the western one-quarter is in the Mississippi Alluvial Plain section of the Coastal Plain province (Fenneman, 1938, p. 65-99). In Tennessee, the Coastal Plain may be subdivided into the West Tennessee Uplands and the West Tennessee Plain (Miller, 1974, p. 7). The Coastal Plain area of the county is entirely in the West Tennessee Plain. Figure 7 shows the generalized topography and major geomorphic subdivisions in the county.

The Coastal Plain (or West Tennessee Plain) in Lauderdale County is characterized by gently rolling to steep topography formed as the result of erosion of geologic formations of Tertiary and Quaternary age. During the later stages of Pleistocene glaciation this topography was covered by a relatively thick blanket of loess, which makes up the present land surface. The topography is broken at many places by the flat-lying flood plains of streams that cross the area. Perhaps the most distinctive feature of the Coastal plain is the loess covered bluffs that rise abruptly above the 


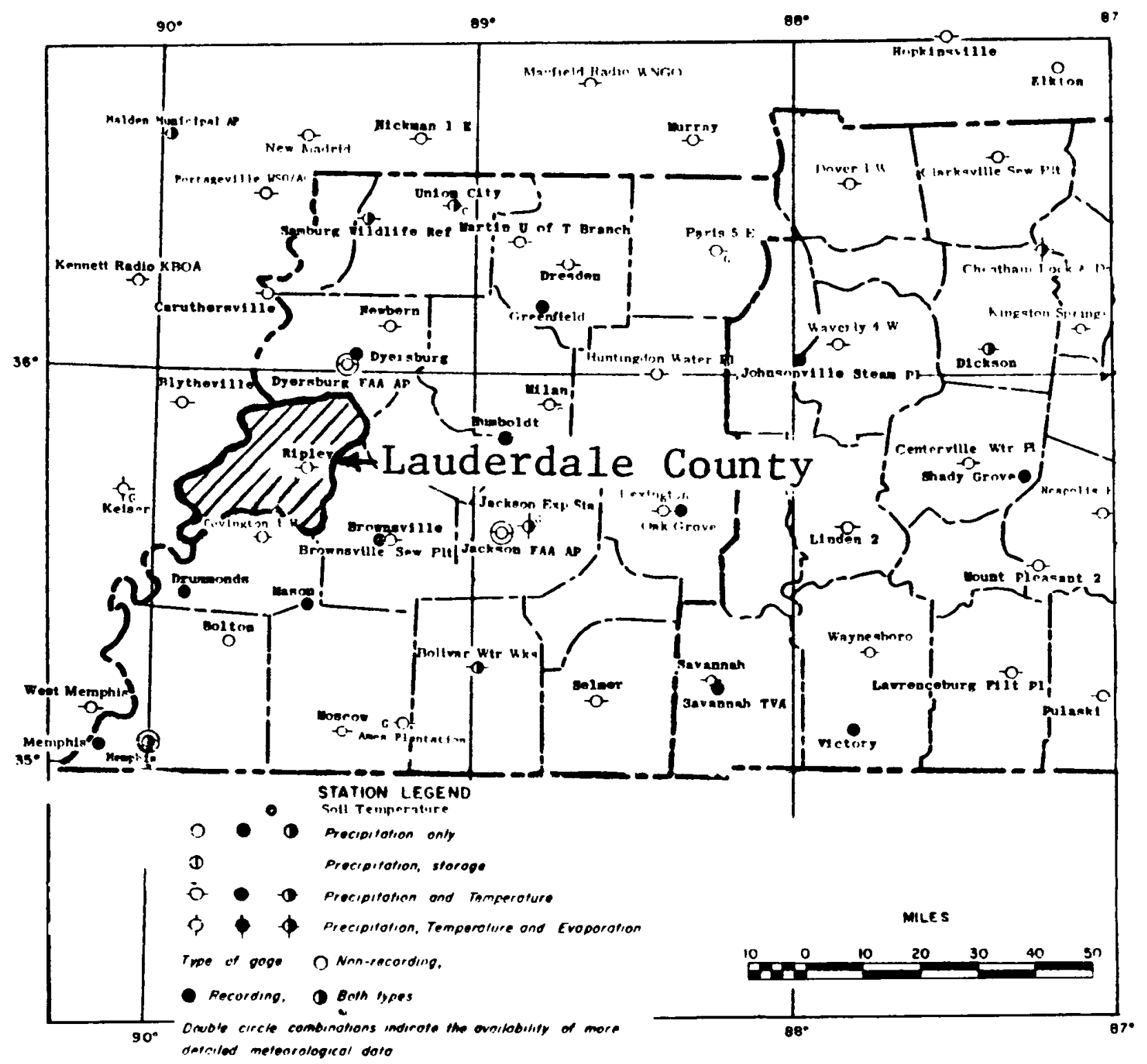

Figure 6.--Weather stations of National Oceanic and Atmospheric Administration in vicinity of Lauderdale County (modified from "Climatological Data" for Tennessee, v. 84, no. 4, April 1979). 


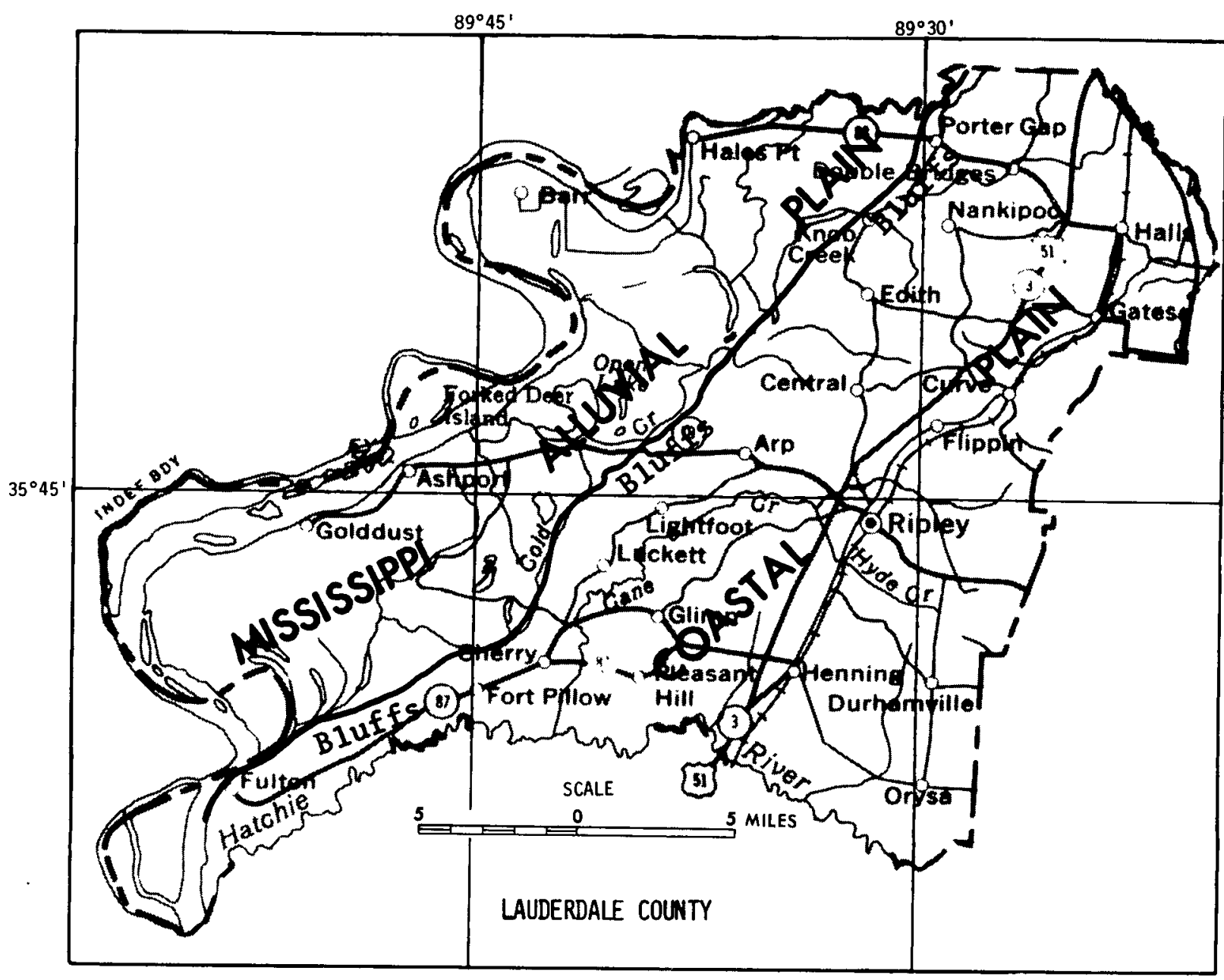

EXPLANATION

Gently rolling to steep topography of the Coastal Plain terminates at a line of bluffs that mark the boundary with the flat-lying Mississippi Alluvial Plain.

Figure 7.--Generalized topography and major geomorphic subdivisions. 
Mississippi Alluvial Plain at its eastern boundary. Land surface altitudes in the Coastal plain are as low as $215 \mathrm{ft}$ above sea level on the banks of the Hatchie River where it enters the Mississippi Alluvial Plain in the southwestern part of the county and are as high as $520 \mathrm{ft}$ above sea level on hills near the communities of Dry $\mathrm{Hill}$ and Edith in the north-central part. Maximum local relief between the Coastal Plain and the Mississippi Alluvial Plain is about $250 \mathrm{ft}$ on the bluffs west of Edith in the northern part.

The Mississippi Alluvial plain in Lauderdale County is a relatively flat-lying area averaging about $6 \mathrm{mi}$ in width and extending about $35 \mathrm{mi}$ in length in a northeast-southwest direction. The Alluvial Plain is characterized by features typical of fluvial deposition--point bars, abandoned channels, and natural leeves. Local features include alluvial fans deposited outward from the base of the bluffs where streams draining the rugged topography of the dissected Coastal Plain enter the flat-lying Alluvial Plain. Land-surface altitudes in the Alluvial Plain are as low as $210 \mathrm{ft}$ above sea level on the banks of the Mississippi River in the southwestern part of the county and are as high as $290 \mathrm{ft}$ above sea level on the alluvial fan of Knob Creek in the northern part. Maximum local relief is probably no more than 10 or $20 \mathrm{ft}$.

Lauderdale County is in the north-central part of the Mississippi embayment, a broad trough or syncline that plunges southward along an axis which approximates the Mississippi River (Cushing and others, 1964, p. B21). This trough or syncline is filled with a wedge of several thousand feet of sediments of Cretaceous, Tertiary, and Quaternary age. These sediments make up geologic formations that dip gently westward into the embayment and southward down its axis. At present not much is known specifically concerning the existance of local structures such as faults. Figure 8 shows the regional location of Lauderdale County, and figure 9 is a diagrammatic crosssection of the Mississippi embayment.

The surface geology of Lauderdale County for the most part is relatively uncomplicated. The oldest geologic units at the surface are the cockfield Formation of the $\mathrm{Claiborne}$ Group and the overlying Jackson Formation. Because of a similarity in lithology, these units cannot be subdivided on the basis of present information so in this report they are referred to as "Jackson and cockfield Formations".

The Jackson and Cockfield Formations are exposed locally in the Coastal Plain at the lower altitudes along the bluffs and in stream channels. Above the Jackson and Cockfield are the fluvial deposits (terrace deposits) which are erosional remnants of ancient alluvial deposits of present streams or an ancient drainage system (Russell and Parks, 1975, p. B30). The fluvial deposits are exposed locally along the bluffs, on the steep valley walls, and in sand and gravel pits. The loess, which is primarily wind-blown silt, forms the principal surface formation in the Coastal plain. The loess covers the underlying fluvial deposits and Jackson and Cockfield Formations at most places. The youngest geologic unit in the county is the alluvial deposits (alluvium) which underlies the Mississippi Alluvial plain and the flood plains of streams in the county. Figure 10 shows the generalized surface geology of the county. 


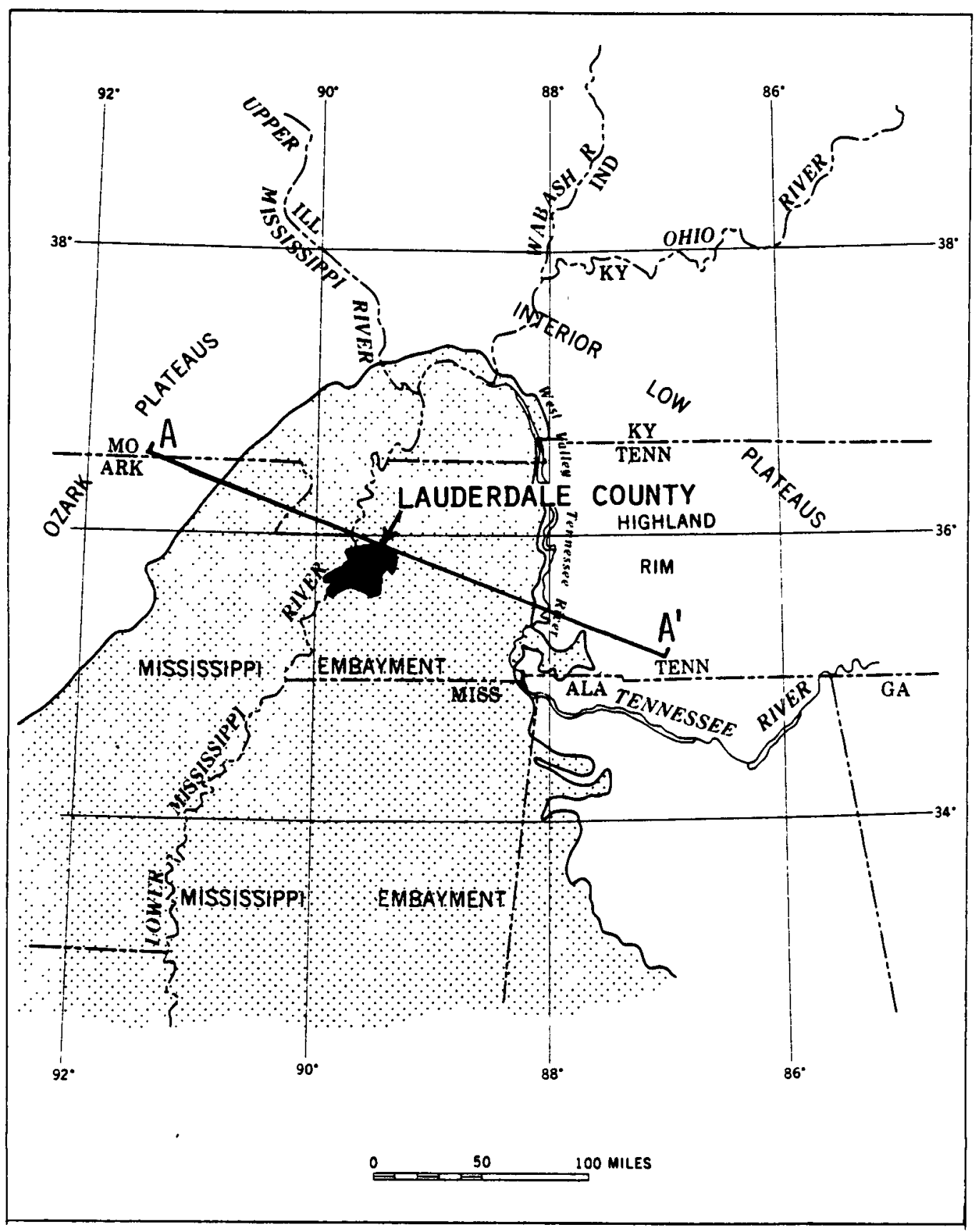

Figure 8.--Regional setting of Lauderdale County in the Mississippi embayment and location of cross-section $A-A^{\prime}$ shown in figure 9 (modified from Stearns and Wilson, 1972, fig. 2.9A-1). 


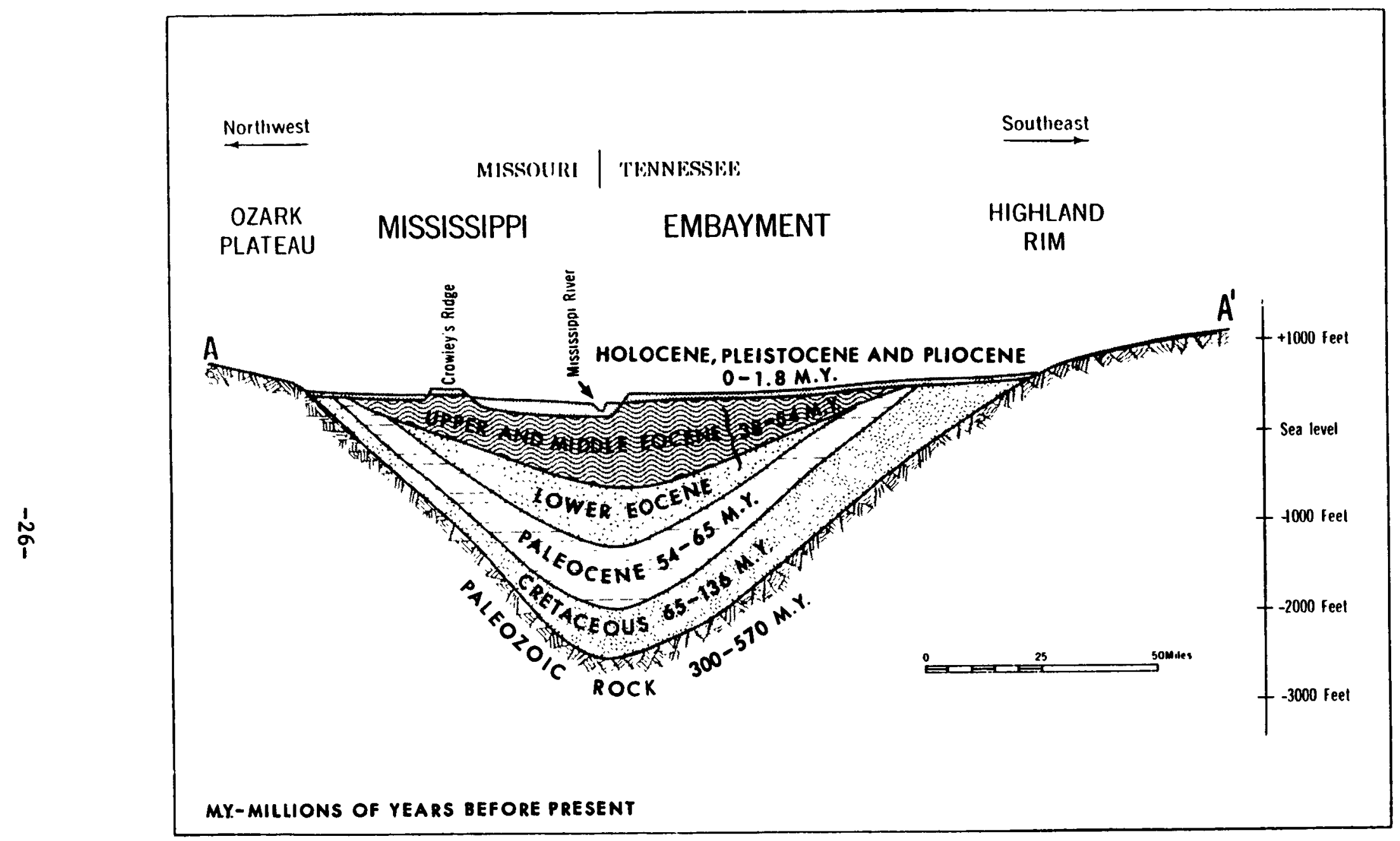

Figure 9--Diagrammatic cross-section showing the age of rocks of the Mississippi embayment--location shown in Figure 8 (modified from Stearns and HIIson, 1972, fig. 2.9A-40). 


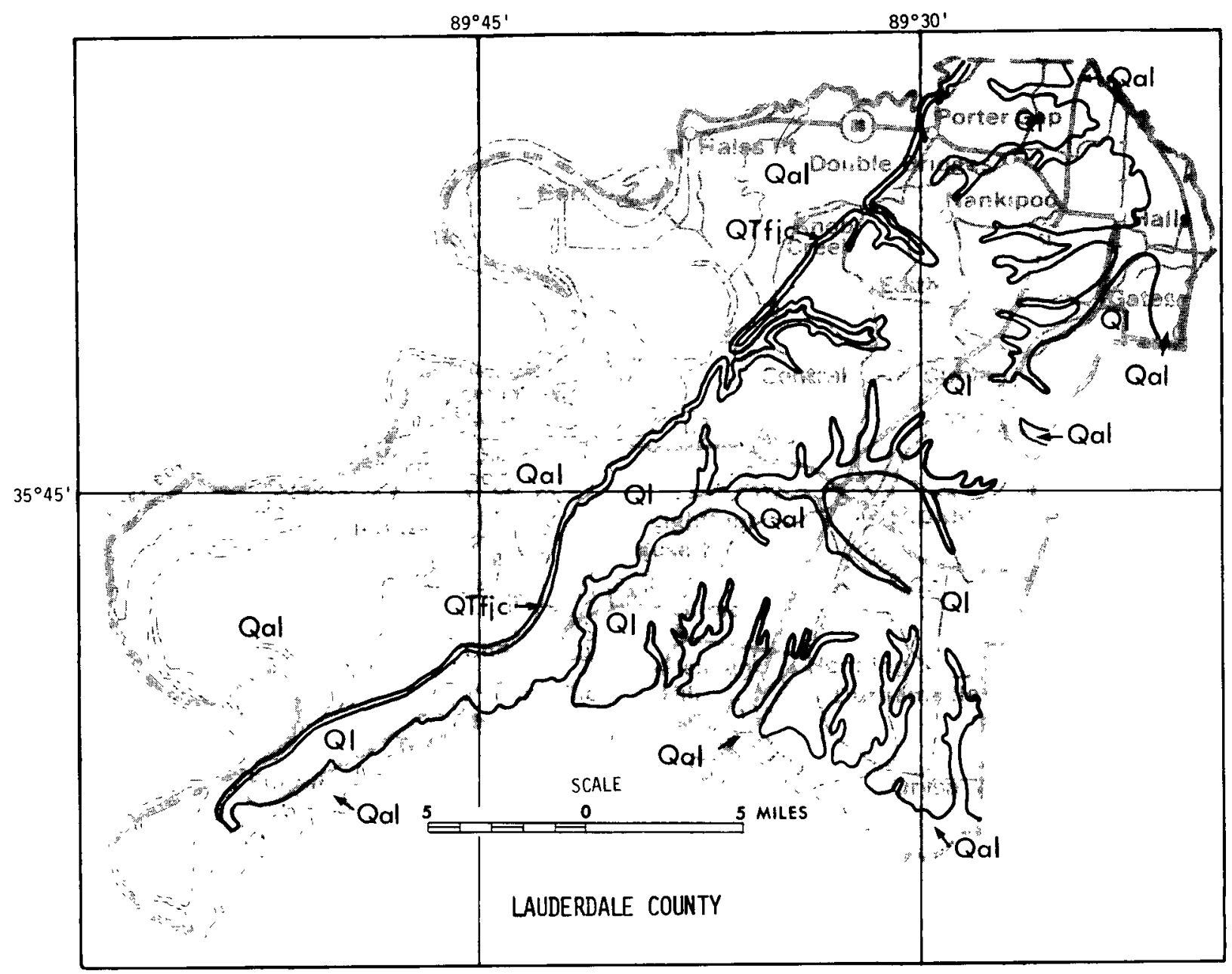

EXPLANATION

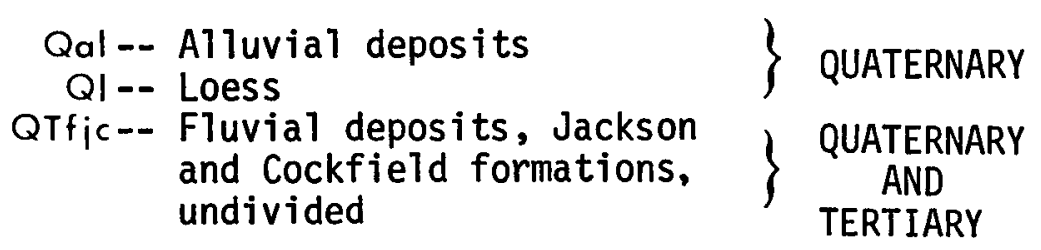

Figure 10.--Generalized surface geology. 
Lauderdale County is in a seismically active region and has been subject to major earthquakes in the past. The severest earthquakes known to have occurred in this region during recorded history were the three principal shocks of the new Madrid earthquakes of 1811-12. These principal shocks were also the severest earthquakes experienced within historic time in the central and eastern United States (Nuttli, 1974).

\section{Water Use}

Water use in Lauderdale County was inventoried in 1970 by Kernodle and Wilson (1973, tables 1-4) as part of a state-wide water-use survey. At that time, water use in the county amounted to an average daily withdrawal of about $3.5 \mathrm{Mgal} / \mathrm{d}$ of which $1.5 \mathrm{Mgal} / \mathrm{d}$ was ground water and $2.0 \mathrm{Mgal} / \mathrm{d}$ was surface water. The ground water was chiefly for municipal, industrial, commercial, and domestic use, and the surface water was for agricultural use. The report showed that 12 major users in the county were canvassed during the survey; the many domestic and farm wells were not canvassed.

\section{Ground-Water System}

From about 2,500 to 3,000 ft of sand, clay, silt, gravel, and lignite underlie Lauderdale County above the Paleozoic rocks. These deposits make up geologic units ranging in age from Late Cretaceous to Holocene. Although much of this sequence is saturated with fresh water (less than 1,000 $\mathrm{mg} / \mathrm{L}$ of dissolved solids), only the post-Midway units (Wilcox Group and younger) will be considered in this report because these units contain the principal aquifers for present and future use. Table 2 gives the stratigraphic relations of the post-Midway geologic units and their hydrologic significance; figure 11 is a geohydrologic cross-section of western Tennessee through Lauderdale County.

Ground-water supplies in Lauderdale county are now derived from several aquifers, as follows: (1) Mississippi alluvial deposits, (2) fluvial deposits, (3) Jackson and Cockfield Formations and (4) Memphis Sand. The alluvial deposits beneath the flood plains of the streams in the county-particularly the Hatchie River and the South Fork Forked Deer River--may provide water to a few shallow wells. These deposits, however, are not described in this report because they are not considered an important source of ground-water supply.

An aquifer not presently used but worthy of mention is the Fort Pillow Sand ("1400-foot" sand). Although this aquifer is deeper than the Memphis Sand and does not have aquifer characteristics to produce as much water, the Fort pillow Sand may have potential for supplying somewhat better quality water than is available from the shallow aquifers, as in northern Mississippi and eastern Arkansas. However, specific data on the quality of water from the Fort Pillow Sand in Lauderdale county are not available.

Table 3 gives records of wells in Lauderdale county for which waterquality analyses are available; figure 12 shows locations of these wells; table 4 gives analyses of the water. 


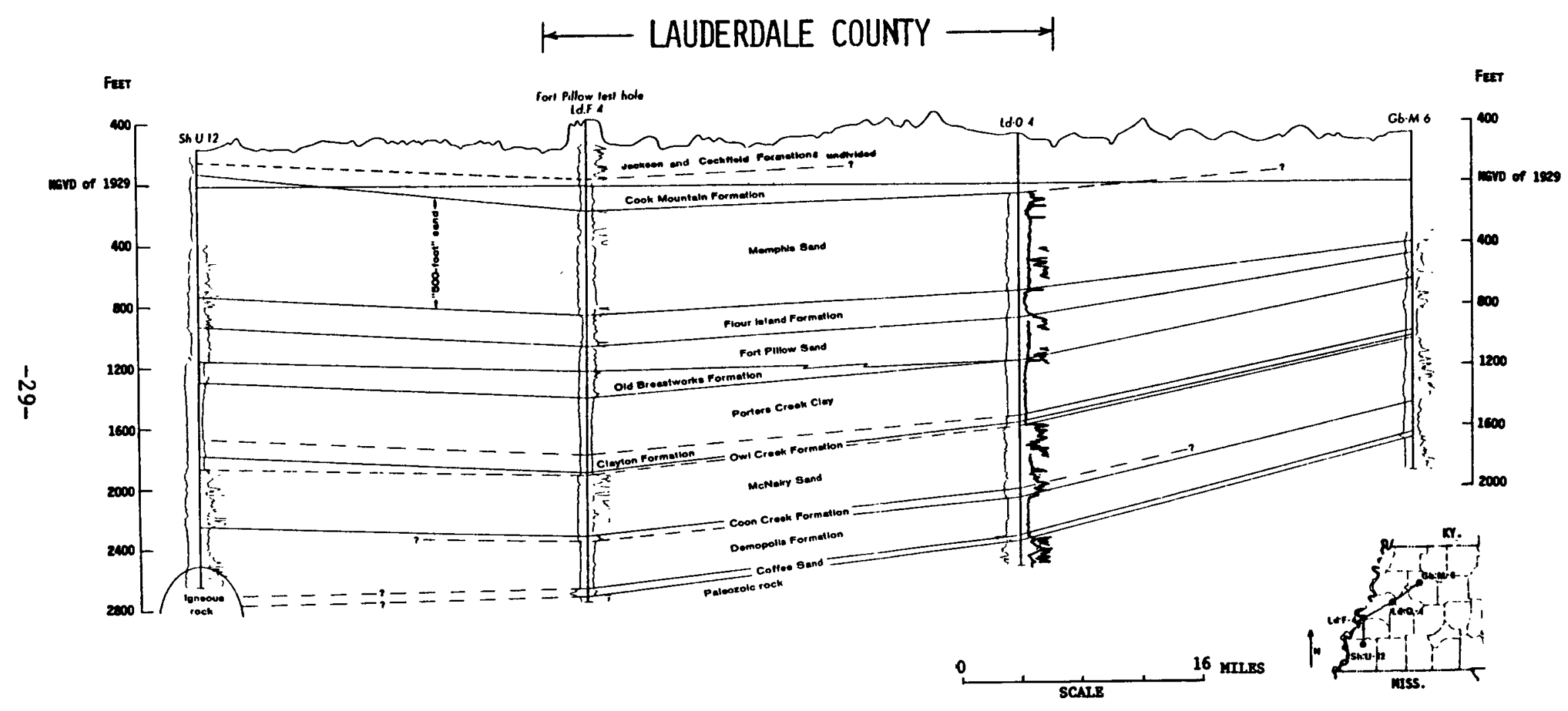

Figure 11:-Geohydrologic electric-log cross-section of western Tennessee through Lauderdale County (modified from Moore and Brown, 1969). 
Table 2.--Post-Midway geologic units underlying Lauderdale

\begin{tabular}{|c|c|c|c|c|}
\hline System & Series & Group & Stratigraphic unit & $\begin{array}{l}\text { Thickness } \\
(\mathrm{ft})\end{array}$ \\
\hline \multirow{2}{*}{ Quaternary } & $\begin{array}{l}\text { Holocene } \\
\text { and } \\
\text { Pleistocene }\end{array}$ & & $\begin{array}{c}\text { Alluvial deposits } \\
\text { (alluvium) }\end{array}$ & $0-200$ \\
\hline & Pleistocene & & Loess & $0-80$ \\
\hline $\begin{array}{l}\text { Quaternary } \\
\text { and } \\
\text { Tertiary (?) }\end{array}$ & $\begin{array}{l}\text { Pleistocene } \\
\text { and } \\
\text { Pliocene (?) }\end{array}$ & & $\begin{array}{l}\text { Fluvial deposits } \\
\text { (terrace deposits) }\end{array}$ & $0-100$ \\
\hline \multirow{6}{*}{ Tertiary } & \multirow{5}{*}{ Eocene } & \multirow{3}{*}{ Claiborne } & $\begin{array}{c}\text { Jackson Formation } \\
\text { and } \\
\text { Cockfield Formation } \\
\text { of Claiborne Group }\end{array}$ & $0-400$ \\
\hline & & & $\begin{array}{l}\text { Cook Mountain } \\
\text { Formation }\end{array}$ & $30-200$ \\
\hline & & & $\begin{array}{c}\text { Memphis Sand } \\
\text { ("500-foot" sand) }\end{array}$ & $650-700$ \\
\hline & & \multirow{3}{*}{ Wilcox } & $\begin{array}{l}\text { Flour Island } \\
\text { Formation }\end{array}$ & $150-200$ \\
\hline & & & $\begin{array}{l}\text { Fort Pillow Sand } \\
\text { ("1400-foot" sand) }\end{array}$ & $150-300$ \\
\hline & Paleocene & & $\begin{array}{l}\text { Old Breastworks } \\
\text { Formation }\end{array}$ & $0-300$ \\
\hline
\end{tabular}

${ }^{2}$ Stratigraphic nomenclature and usage modified from Moore and Brown (1969). 
County and their hydrologic significance ${ }^{1}$

Lithology and hydrologic significance

Sand, gravel, silt, and clay. Underlies the Mississippi Alluvial Plain and flood plains of other streams. Thickest beneath the Alluvial Plain; probably no more than $50 \mathrm{ft}$ elsewhere. Supplies water to domestic and farm wells in the Alluvial Plain where this aquifer has potential for large capacity wells to provide a source of irrigation water.

Silt, silty clay, and minor sand. Forms principal formation at the surface in the Coastal plain. Thickest on bluffs that border Mississippi Alluvial

Plain. Not an aquifer; tends to retard downward movement of water recharging the water-table aquifers.

Sand, gravel, and minor clay. Generally underlies the loess in the Coastal Plain, but locally may be absent. Thickness highly variable because of erosional surfaces at top and base. Locally supplies water to domestic, farm, and municipal wells where of sufficient thickness and contains enough water.

Sand, silt, clay, and lignite. Because of similarities in lithology, the Jackson and cockfield cannot be subdivided based on available information. Preserved section probably mostly cockfield, but at places upper part includes the Jackson. Principal aquifer in the Coastal Plain supplying water for domestic, farm, commercial, industrial, and municipal use.

Clay, silt, sand, and lignite. Identified in Fort Pillow test well; not enough information available to identify elsewhere. Believed to consist generally of clay and silt, but locally may consist largely of sand. Forms upper confining bed for the Memphis Sand where chiefly clay and silt.

Sand, silt, and clay. Consists of a thick body of sand with lenses of clay and silt at various stratigraphic horizons. Thickest in southern part of county. Used for public, municipal, commercial, and industrial supplies where shallower aguifers do not yield enough water for installation of large capacity wells.

Silt, clay, and sand. Not an aquifer; serves as lower confining bed for the Memphis Sand and upper confining bed for Fort Pillow Sand.

Sand and minor clay. Relatively deep aquifer not presently used in the county because of the availability of water at shallower depths. May have potential for supplying water of better quality than available from shallower aquifers, but specific information on ground-water quality not available.

Silt, clay, sand, and lignite. Not an aquifer. Thickest in southern part of County; may be absent in northern part. Serves as the lower confining bed for the Fort Pillow Sand. Underlain by the Porters Creek Clay of the Midway Group. 
Table 3.--Records of wells in Lauderdale

[See figure 12 for well locations

\begin{tabular}{|c|c|c|c|c|c|}
\hline $\begin{array}{c}\text { Well } \\
\text { number }\end{array}$ & Owner & $\begin{array}{l}\text { Type } \\
\text { of } \\
\text { well }\end{array}$ & $\begin{array}{c}\text { Date } \\
\text { drilled }\end{array}$ & $\begin{array}{l}\text { Alti- } \\
\text { tude } \\
\text { (ft) }\end{array}$ & $\begin{array}{r}\text { Wel1 } \\
\text { depth } \\
(f t)\end{array}$ \\
\hline
\end{tabular}

MISSISSI PPI

\begin{tabular}{|c|c|c|c|c|c|}
\hline$s-1$ & T. C. Meeks & Driven & --- & 258 & 20 \\
\hline 25 & As hport & do & --- & 251 & 23 \\
\hline$F-2$ & T. E. Hutcherson & do & --- & 246 & 35 \\
\hline$M-2$ & James Porter & do & --- & 251 & 36 \\
\hline$M-3$ & E. M. Harrison & do & --- & 252 & 44 \\
\hline$R-1$ & F. E. Pough & Drilled & --- & 262 & 59 \\
\hline
\end{tabular}

FLUVIAL

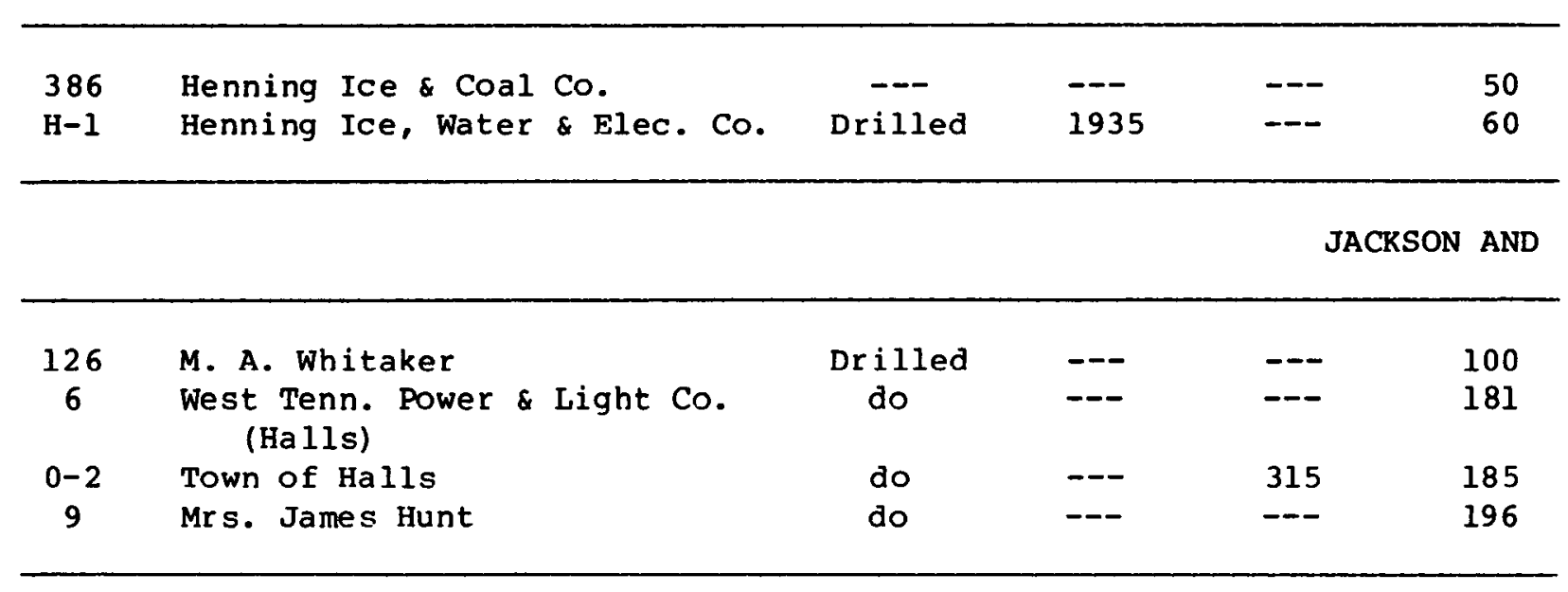

MEMPHIS

\begin{tabular}{|c|c|c|c|c|c|}
\hline $\mathrm{M}-\mathrm{A}$ & E. M. Harrison & Drilled & --- & 252 & 396 \\
\hline $38 c$ & Henning Ice \& Coal Co. & do & --- & --- & 440 \\
\hline $\mathrm{H}-3$ & Henning Ice, water \& Elec. Co. & do & 1936 & 295 & 480 \\
\hline G-5 & Fort Pillow State Prison Farm & do & 1957 & 270 & 656 \\
\hline 21 & $\begin{array}{l}\text { West Tenn. Power \& Light Co. } \\
\text { (Ripley) }\end{array}$ & do & --- & --- & 695 \\
\hline $\mathrm{H}-5$ & Town of Ripley & do & 1942 & 427 & 755 \\
\hline $\mathrm{H}-6$ & Town of Ripley & do & 1951 & 414 & 755 \\
\hline$F-4$ & U.S. Geological survey & do & 1965 & 437 & 879 \\
\hline
\end{tabular}

\footnotetext{
1 Well numbers with letters preceding number, e.g. H-3, are U.S.G.S. Iocal
} Lauderdale county; other numbers correspond to those given in wells 
County for which water guality analyses are available and table 4 for water analyses]

\begin{tabular}{|c|c|c|c|c|c|}
\hline Wel1 & water & leve 1 & Pumping & Me thod & Use \\
\hline $\begin{array}{c}\text { diameter } \\
\text { (in.) }\end{array}$ & $\begin{array}{l}\text { Depth } \\
(f t)\end{array}$ & Date & $\begin{array}{c}\text { rate } \\
\text { (gal/min) }\end{array}$ & $\begin{array}{c}\text { of } \\
\text { lift }\end{array}$ & $\begin{array}{c}\text { of } \\
\text { water }\end{array}$ \\
\hline
\end{tabular}

ALLUVIAL DEPOSITS

\begin{tabular}{lrrrrl}
\hline $1 \frac{1}{4}$ & 4 & $5-56$ & --- & Pitcher pump & Domestic \\
$1 \frac{1}{2}$ & --- & --- & -- & do & do \\
$1 \frac{1}{4}$ & 17 & $3-56$ & -- & do & Domestic, stock \\
$1 \frac{1}{4}$ & 8 & $3-56$ & -- & do & Domestic \\
$1 \frac{1}{4}$ & 7 & $3-56$ & -- & do & Domestic, stock \\
2 & 13 & $9-56$ & -- & do & Domestic \\
\hline
\end{tabular}

DEPOSITS

\begin{tabular}{crrrr}
\hline 4 & ---- & --- & $\begin{array}{l}\text { Lift pump } \\
\text { Turbine }\end{array}$ & $\begin{array}{r}\text { Public supply } \\
\text { do }\end{array}$ \\
\hline
\end{tabular}

COCKFIELD FORMATIONS

\begin{tabular}{|c|c|c|c|c|c|}
\hline 2 & --- & -- & --- & Lift pump & Domestic \\
\hline 8 & -- & --- & 70 & Lift pump, elec. & --- \\
\hline 4 & 60 & 1953 & 304 & Turbine & Public supply \\
\hline 2 & --- & --- & -- & Lift pump & Domestic \\
\hline
\end{tabular}

SAND

\begin{tabular}{|c|c|c|c|c|c|}
\hline 2 & +3 & $9-58$ & --- & Pitcher pump & Unused \\
\hline 4 & --- & --- & -- & Lift pump & Public supply \\
\hline 4 & --- & --- & 60 & Turbine & do \\
\hline $10 \times 6$ & 26 & $8-57$ & 600 & Turbine & do \\
\hline--- & --- & --- & 250 & Air lift & do \\
\hline 12 & 165 & 1953 & 350 & Turbine & do \\
\hline 12 & 140 & $5-60$ & 400 & do & do \\
\hline $6 \times 3$ & 198 & $11-65$ & --- & None & Observation well \\
\hline
\end{tabular}

well-numbering system for Tennessee and are generally prefixed "Ld:" for (1933; p. 217-220). 
Table 4.--Water guality analyses [Dissolved constituents and hardness in milligrams per liter;

\begin{tabular}{cccccccccc}
\hline & Well & Year of & & Cal- & Mag- & Potas- & Bicar- \\
Well & depth & collec- \\
number & $(\mathrm{ft})$ & tion & $\left(\mathrm{SiO}_{2}\right)$ & $(\mathrm{Fe})$ & $\begin{array}{c}\text { cium } \\
(\mathrm{Ca})\end{array}$ & $\begin{array}{c}\text { nesium } \\
(\mathrm{Mg})\end{array}$ & $\begin{array}{c}\text { Sodium } \\
(\mathrm{Na})\end{array}$ & $\begin{array}{c}\text { sium } \\
\text { (K) }\end{array}$ & $\begin{array}{c}\text { bonate } \\
\left(\mathrm{HCO}_{3}\right)\end{array}$ \\
\hline
\end{tabular}

MISS ISSIPPI

\begin{tabular}{lllllllllr}
\hline $\mathrm{S}-1$ & 20 & 1956 & 26 & 0.13 & 6.4 & 1.5 & 6.7 & 0.8 & 18 \\
25 & 23 & 1929 & 26 & 1.7 & 97 & 34 & 2.0 & 1.5 & 434 \\
$\mathrm{~F}-2$ & 35 & 1956 & 28 & 15 & 101 & 33 & 5.2 & 1.8 & 478 \\
$\mathrm{M}-2$ & 36 & 1956 & 25 & 12 & 101 & 28 & 5.9 & 2.2 & 438 \\
$\mathrm{M}-3$ & 44 & 1955 & 37 & 19 & 111 & 40 & 10 & 2.6 & 574 \\
$\mathrm{R}-1$ & 59 & 1956 & 29 & 16 & 110 & 24 & 20 & 2.2 & 459 \\
\hline
\end{tabular}

FLUVIAL

\begin{tabular}{|c|c|c|c|c|c|c|c|c|c|}
\hline $38 b$ & 50 & 1929 & 41 & .02 & 38 & 24 & 5.9 & 1.2 & 185 \\
\hline $\mathrm{H}-1$ & 60 & 1951 & 42 & .18 & 55 & 31 & 14 & .9 & 211 \\
\hline
\end{tabular}

JACKSON AND

\begin{tabular}{cccccccccc}
\hline $12 \mathrm{~b}$ & 100 & 1929 & 14 & 41 & 15 & 9.4 & 5.1 & 1.8 & 102 \\
6 & 181 & 1929 & 22 & 1.7 & 33 & 19 & 5.7 & 1.1 & 196 \\
$0-2$ & 185 & 1951 & 19 & 1.9 & 24 & 12 & 7.9 & 1.4 & 144 \\
9 & 196 & 1929 & 17 & 1.8 & 68 & 41 & 7.6 & .9 & 410 \\
\hline
\end{tabular}

MEMPHIS

\begin{tabular}{lrrrrrrrrr}
\hline $\mathrm{M}-4$ & 396 & 1958 & 18 & 16 & 18 & 8.3 & 5.5 & 6.6 & 117 \\
$38 \mathrm{C}$ & 440 & 1929 & 12 & 5.6 & 17 & 8.7 & 6.9 & 1.6 & 105 \\
$\mathrm{H}-3$ & 480 & 1951 & 13 & 6.6 & 17 & 11 & 8.7 & 3.4 & 122 \\
$\mathrm{G}-5$ & 656 & 1960 & -- & 10 & 18 & 11 & --- & -- & 119 \\
21 & 695 & 1929 & 14 & 6.1 & 18 & 10 & 6.1 & 1.6 & 113 \\
$\mathrm{H}-5$ & 755 & 1951 & 8.8 & 4.5 & 18 & 9.5 & 7.3 & 2.9 & 114 \\
$\mathrm{H}-6$ & 755 & 1961 & 5.0 & 2.4 & 17 & 9.3 & 6.3 & 1.9 & 109 \\
$\mathrm{~F}-4$ & 879 & 1965 & 11 & 2.0 & 47 & 12 & 11 & .6 & 228 \\
\hline
\end{tabular}

1 Well numbers with letters preceding number, e.g. H-3, are U.S.G.S. local wellCounty; other numbers correspond to those given in wells (1933, p. 217-220).

2 Temperatures converted from ${ }^{\circ} \mathrm{F}$ to ${ }^{\circ} \mathrm{C}$ and rounded to the nearest half degree. 
from wells in Lauderdale county

see figure 12 for well locations and table 3 for well records ]

\begin{tabular}{|c|c|c|c|c|c|c|c|c|c|}
\hline & & & & & & & & 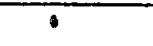 & \\
\hline $\begin{array}{l}\mathrm{Su}{ }^{-} \\
\text {fate } \\
\left(\mathrm{SO}_{4}\right)\end{array}$ & $\begin{array}{l}\text { Chlo- } \\
\text { ride } \\
\text { (Cl) }\end{array}$ & $\begin{array}{l}\text { Fluo- } \\
\text { ride } \\
\text { (F) }\end{array}$ & $\begin{array}{l}\mathrm{Ni}- \\
\text { trate } \\
\left(\mathrm{NO}_{9}\right) \\
\text { as } \mathrm{N}\end{array}$ & $\begin{array}{c}\text { Dis- } \\
\text { solved } \\
\text { solids } \\
\text { (residue) }\end{array}$ & $\begin{array}{l}\text { Hard- } \\
\text { ness } \\
\text { as } \\
\mathrm{CaCO}_{3}\end{array}$ & $\begin{array}{l}\text { Specific } \\
\text { conductance } \\
\text { (Micrombos } \\
\text { at } 25^{\circ} \mathrm{C} \text { ) }\end{array}$ & $\begin{array}{c}\mathrm{pH} \\
\text { (units) }\end{array}$ & $\begin{array}{l}\text { Color } \\
\text { (units) }\end{array}$ & $\begin{array}{l}\text { Temper- } \\
\text { ature } \\
{ }^{\circ} \mathrm{C}^{2} .\end{array}$ \\
\hline
\end{tabular}

ALLUVIAL DEPOSITS

\begin{tabular}{crrrrrrrrr}
\hline 11 & 7.3 & 0.1 & 5.0 & 78 & 25 & 111 & 6.0 & 3 & 14 \\
16 & 6.8 & -- & 2.6 & 373 & 382 & --- & --- & --- & 17 \\
5.3 & 1.2 & .2 & .7 & 409 & 390 & 720 & 6.9 & 6 & 15 \\
13 & 3.5 & .4 & .7 & 400 & 370 & 694 & 7.0 & 15 & 16 \\
1.5 & 1.0 & .4 & .9 & 491 & 443 & 833 & 6.8 & 15 & 15 \\
42 & 2.0 & .2 & .3 & 456 & 379 & 750 & 6.9 & 2 & 15.5 \\
\hline
\end{tabular}

DEPOSITS

\begin{tabular}{cccccccccc}
\hline 8.0 & 14 & -- & 29 & 236 & 193 & --- & --- & -- & 17 \\
23 & 37 & .0 & 58 & 382 & 264 & 563 & 6.3 & 5 & 16.5 \\
\hline
\end{tabular}

COCKFIELD FORMATIONS

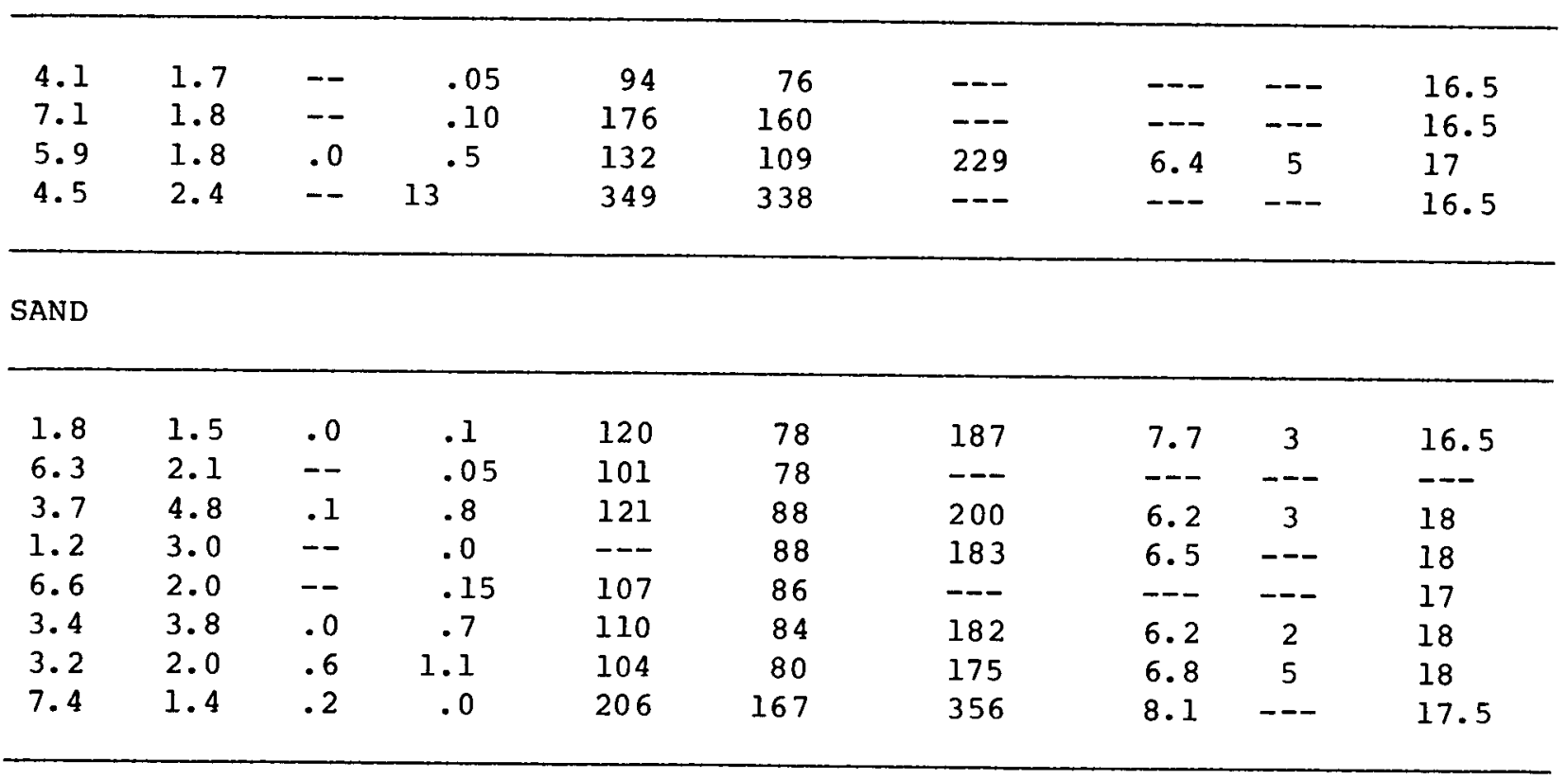

numbering system for Tennessee and are generally prefixed "Ld:" for Lauderdale 


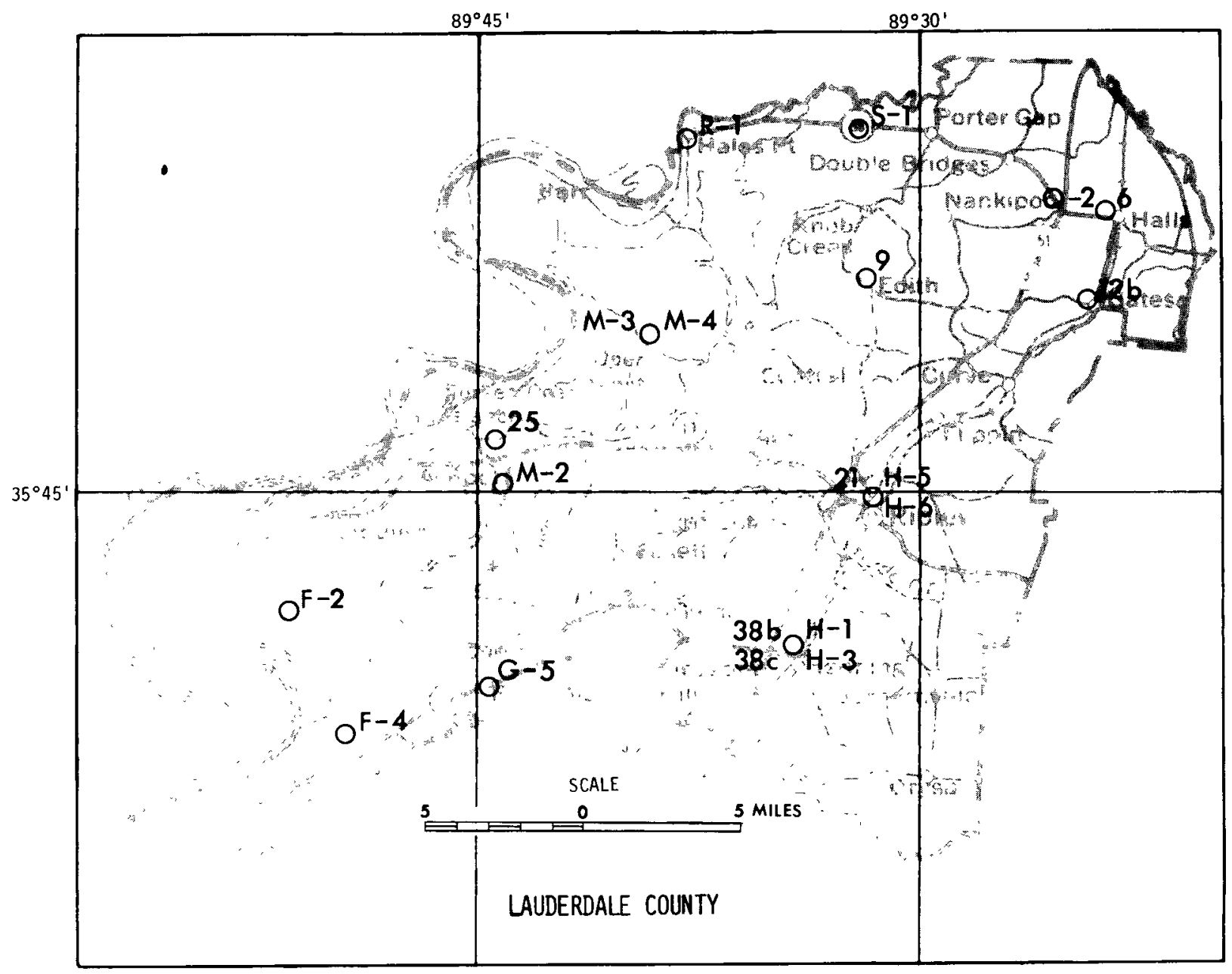

EXPLANATION

We11 numbers with letters preceding number, for example, $\mathrm{H}-3$, are local wel1-numbering system of U. S. Geological Survey for Tennessee and are generally prefixed "Ld:" for Lauderdale County; other numbers correspond to those given in Wells (1938, p. 217-220). See table 3 for well records and table 4 for water analyses.

Figure 12.--Wells for which water-quality analyses are available. 
The Mississippi alluvial deposits underlie the Mississippi Alluvial Plain in western Lauderdale County. These deposits consist generally of relatively impermeable fine sand, silt, and clay in the upper part and permeable sand and gravel in the lower part. The alluvial deposits locally may be as much as $200 \mathrm{ft}$ thick, but probably are more commonly 100 to $150 \mathrm{ft}$ thick. The lower sand and gravel is about nine-tenths to three-quarters of the thickness of the alluvial deposits and provides a source of water for domestic and farm wells.

Wells in the Mississippi alluvial deposits are shallow, ranging from about 10 to $110 \mathrm{ft}$ in depth. For domestic and farm supplies these wells are typically of small capacity, pumping from about 5 to $25 \mathrm{gal} / \mathrm{min}$. Nevertheless, according to Strausberg and Schreurs (1958, p. 4), this aquifer is known to have potential for large capacity wells of 1,500 to $4,000 \mathrm{gal} / \mathrm{min}$ to provide a source of irrigation water.

Water levels in the Mississippi alluvial deposits range from near land surface to about $35 \mathrm{ft}$ below land surface. According to strausberg and Schreurs (1958, p. 37), hydrographs of observation wells show that water levels in the alluvial deposits fluctuate in response to seasonal or longterm changes in stage of the Mississippi River as far as $3 \mathrm{mi}$ away.

Water from the Mississippi alluvial deposits is typically very hard and is high in iron and dissolved solids (table 4). At places, shallower wells provide softer water with less iron and dissolved solids than the deeper ones, probably because of infiltration of water to the aquifer from nearby streams or lakes.

\section{Fluvial Deposits}

The fluvial deposits comprise a local water-table aguifer beneath the loess in the Coastal plain. These deposits consist chiefly of sand or sand and gravel with clay present as small lenses or balls and fragments. The fluvial deposits drape over the Jackson and Cockfield Formations from high to low altitudes and commonly merge with the alluvial deposits of present streams, except along the bluffs facing the Mississippi Alluvial plain. The fluvial deposits are generally less than $100 \mathrm{ft}$ thick and at places may be absent. This aguifer provides a local source of water for domestic, farm, and municipal wells where it is of sufficient thickness and contains, enough water.

Wells in the fluvial deposits are less than $100 \mathrm{ft}$ deep and are small capacity, pumping from about 5 to $50 \mathrm{gal} / \mathrm{min}$. At one time this aguifer probably was used extensively for dug and bored wells, but many shallow wells have been replaced with deeper wells in other aquifers to meet increased demands for water and to avoid contamination.

Water levels in the fluvial deposits are highly variable from place to place because the water-table configuration is controlled largely by the topography. Water levels, however, probably range from about 20 to $90 \mathrm{ft}$ below land surface. Water levels are generally at higher altitudes but at greater depths beneath hill tops and ridges and at lower altitudes but at lesser depths beneath the valley slopes. 
Water from the fluvial deposits is hard to very hard and high in dissolved solids (table 4). Iron content is locally lower than in water from the deeper aquifers so at places water from the fluvial deposits may be desirable as a source of supply because of lower treatment costs.

Jackson and Cockfield Formations

The Jackson and Cockfield Formations underlie most of the county beneath the alluvial deposits, fluvial deposits, or loess. This unit consists of lenticularly bedded sand, silt, clay and lignite. Not much specific information is available about the thickness of the Jackson and Cockfield Formations. However, based on the logs of the Fort pillow test well at Fort Pillow State Historic Area, it is about $300 \mathrm{ft}$ thick. In other areas of the county, the aquifer probably ranges from about $0 \mathrm{ft}$ to $400 \mathrm{ft}$ in thickness. This is the principal aquifer utilized in the coastal plain, providing water for domestic, farm, commercial, industrial, public and municipal supplies.

Wells in the Jackson and Cockfield Formations are generally less than $500 \mathrm{ft}$ deep and most are less than $200 \mathrm{ft}$ deep. Sands range from very fine to coarse, but commonly are of the finer sizes. These sands give up water to small to moderate capacity wells, pumping from about 5 to 300 $\mathrm{gal} / \mathrm{min}$. A pump test made at the U.S. Military Reservation near Halls in 1961 indicated a transmissivity of about $2,500\left(\mathrm{ft}^{3} / \mathrm{d}\right) \mathrm{ft}$ and a storage coefficient of $3 \times 10^{-4}$ for this aguifer.

Water levels in wells in the Jackson and Cockfield Formations generally range from near land surface to about $200 \mathrm{ft}$ below land surface, depending on location and altitude. Most water-level data available for this aquifer are those supplied by water-well contractors on driller's records filed with the TDWR. Water in this aguifer exists under both water table and confined conditions.

Water from the Jackson and Cockfield Formations is moderately hard to very hard, and dissolved solids range from less than $100 \mathrm{mg} / \mathrm{L}$ to more than $300 \mathrm{mg} / \mathrm{L}$ (table 4). Iron is locally an undesirable constituent, requiring treatment for removal.

\section{Memphis Sand}

The Memphis Sand ("500-foot" sand) is a widespread and important aquifer in western Tennessee. It is the principal aquifer supplying water to the City of Memphis, about $50 \mathrm{mi}$ to the south (Criner and Parks, 1976, p. 5).

In Lauderdale County, the Memphis Sand consists chiefly of a thick body of sand containing subordinate lenses or beds of clay at various stratigraphic horizons. This aquifer is about $650 \mathrm{ft}$ thick to the north in the vicinity of Halls and about $700 \mathrm{ft}$ thick to the south in the Fort Pillow State Historic Area. The Memphis Sand is presently being used for public, municipal, commercial, and industrial supplies where the sands of the shallower aguifers do not yield enough water for the installation of large-capacity wells. 
Wells in the Memphis sand range from about 500 to $800 \mathrm{ft}$ in depth. The sands range from very fine to coarse and supply water to small and large capacity wells, pumping from 30 to $850 \mathrm{gal} / \mathrm{min}$. It is commonly necessary to drill to the middle of the aquifer to find a suitable sand to supply large-capacity wells. A pump test made at Ripley in 1961 indicated a transmissivity of $22,400\left(\mathrm{ft}^{3} / \mathrm{d}\right) / \mathrm{ft}$ for this aquifer. A map prepared by Moore $(1965, \mathrm{pl}$. 7) shows a range of apparent and potential transmissivity (transmissibility in Moore's report) for Lauderdale County of about 33,500 to 43,500 ( $\mathrm{ft} 3 / \mathrm{d}) / \mathrm{ft}$ for wells that are partially penetrating and screened in the top of the aquifer.

Water levels in wells in the Memphis Sand range from near land surface to about $250 \mathrm{ft}$ below land surface, depending on location and altitude. Moore (1965, pl. 5) gives a potentiometric-(piezometric) surface map that shows the altitude at which water rose in wells in the Memphis Sand ("500-foot" sand in Moore's report) in January 1960. In addition to water levels reported by water well contractors on driller's logs filed with the TDWR, the Geological Survey maintains an automatic recorder on an observation well at Fort Pillow State Historic Area. Preliminary analysis of the record from this well indicates that water levels in the Memphis Sand respond to large changes in stage on the Mississippi River, about $2.5 \mathrm{mi}$ away at its closest point.

Water from the Memphis Sand is moderately hard and contains small amounts of dissolved solids (table 4). Iron is locally an undesirable constituent, reguiring treatment for removal.

\section{Surface-Water System}

The surface-water drainage system in Lauderdale county is entirely within the Lower Mississippi River Basin and includes parts of the Hatchie River and the Obion River Basins. Natural divides within the county allow subdivision of this drainage system into three areas for the purpose of discussion. These areas are drainage to: (1) the Mississippi River, (2) the Hatchie River, and (3) the South Fork Forked Deer River (Obion River Basin). Figure 13 shows major drainage and generalized flood-prone areas in Lauderdale county; table 5 gives the low-flow characteristics of some streams.

Drainage to Mississippi River

The Mississippi River flows southward along the western boundary of the county except where the boundary follows abandoned courses. Drainage to the Mississippi consists of a complex network of interconnecting streams, lakes, and ditches that drain the flat-lying Mississippi Alluvial Plain and some adjacent uplands of the Coastal Plain. None of the Alluvial Plain is protected by the system of man-made levees along the Mississippi River built and maintained by the Corps of Engineers. Thus a large part of the area is subject to seasonal floods on the Mississippi, and the entire area has been inundated during historic floods. Flow in this network of streams, lakes, and ditches is variable in direction and in the courses followed because of backwater from the Mississippi River during high stages. 


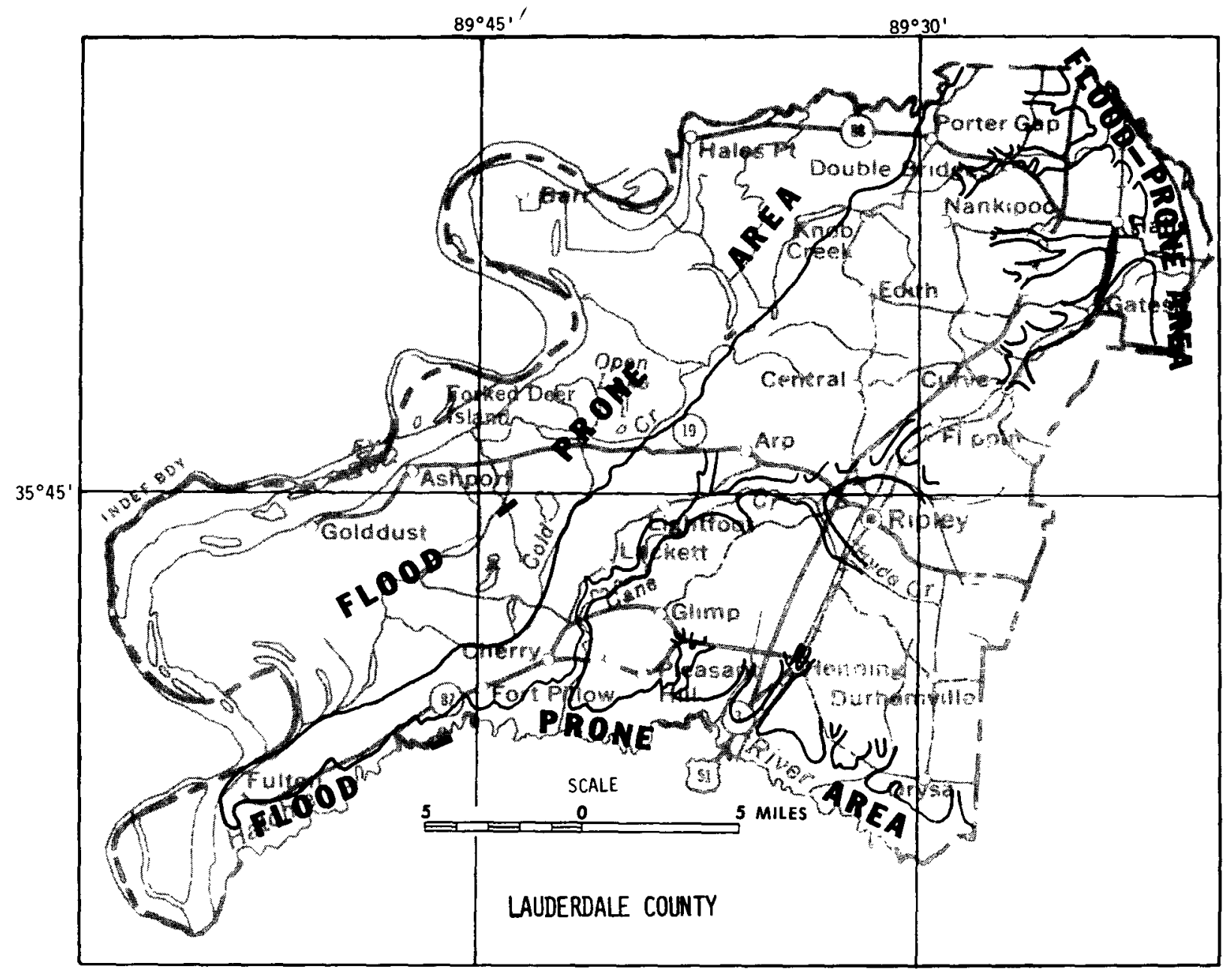

EXPLANATION

Flood-prone areas are generalized from U.S.G.S. maps prepared on 15- and 7.5-minute topographic quadrangles. See "Flood-Prone Area Maps" in text for list of maps and for mapping criteria.

Figure 13.--Major drainage and generalized flood-prone areas. 
Table 5.--Low flow characteristics of some streams in Lauderdale County ${ }^{2}$

[Partial-record stations correlated with daily-record station 07029000, see below]

\begin{tabular}{|c|c|c|c|c|c|c|c|c|}
\hline \multirow{3}{*}{$\begin{array}{l}\text { Station } \\
\text { number } \\
07028000\end{array}$} & \multirow{2}{*}{$\begin{array}{c}\text { Class } \\
\text { of } \\
\text { station }\end{array}$} & \multirow{2}{*}{$\begin{array}{c}\text { Drainage } \\
\text { area } \\
\left(\mathrm{mi}^{2}\right)\end{array}$} & \multicolumn{4}{|c|}{$\begin{array}{l}\left.\text { Annual low flow [in (ft } \mathrm{t}^{\mathrm{s}} / \mathrm{s}\right) \mathrm{mi}^{2} \text { ] } \\
\text { for indicated period of consec- } \\
\text { utive days and for indicated } \\
\text { recurrence interval (in years) } \\
7-\text { day }\end{array}$} & \multicolumn{2}{|c|}{$\begin{array}{l}\text { Flow [in }\left(\mathrm{ft}^{2} / \mathrm{s}\right) / \mathrm{mi}^{2} \text { ] } \\
\text { which was equaled } \\
\text { or exceeded for } \\
\text { indicated percent } \\
\text { of time }\end{array}$} \\
\hline & & & $2-y r$ & $10-y \mathrm{r}$ & $2-y r$ & $10-y \mathrm{r}$ & 90 & 95 \\
\hline & Daily-record & 1,100 & 0.16 & 0.11 & 0.18 & 0.13 & 0.18 & 0.15 \\
\hline 07029200 & Partial-record & 16.4 & .04 & .02 & .06 & .03 & .05 & .04 \\
\hline 07030100 & Partial-record & 30 & .01 & .003 & .02 & .0007 & .02 & .01 \\
\hline 07030140 & Partial-record & 88 & .001 & 0 & .003 & 0 & .002 & .001 \\
\hline
\end{tabular}

1 From speer and others (1965, table 2).

$$
\begin{aligned}
& \text { Station } \\
& \hline 07028000 \\
& 07029000 \\
& 07029200 \\
& 07030100 \\
& 07030140
\end{aligned}
$$

Station name

South Fork Forked Deer River at Chestnut Bluff

Middle Fork Forked Deer River near Alamo

Cold Creek near Arp

Cane Creek at Ripley

Cane Creek near Cherry 
At stages when flow is not affected by backwater from the Mississippi River, drainage in the northern part of the Alluvial plain is into Chisholm Lake and the old Bed Forked Deer River. Principal tributaries are Cold Creek (north one) and Knob Creek. Cold Creek heads in the Coastal Plain northeast of Central and drains the uplands north of Central and Arp. Cold Creek flows westward from the uplands and enters Chisholm Lake at its south end. Knob Creek heads in the Coastal Plain northwest of Dry Hill and drains the uplands north of Edith. Knob Creek flows westward and enters the Old Bed Forked Deer River west of the community of Knob Creek. Other drainage in the northern part of the Alluvial Plain is through Middle Fork Forked Deer River and Waldrons Pocket, both of which drain into the Mississippi.

The central part of the Alluvial plain, for the most part, drains into and out of Open Lake. Several bayous or sloughs drain into open Lake from the east and north, and Lower Forked Deer River provides drainage westward to the Mississippi. Cold Creek (south one) also provides drainage from Open Lake.

The southern part of the Alluvial Plain is drained by cold Creek (south) and its major tributary - Jones Bayou (or Jones Slough). Cold Creek flows southward from open Lake through the southeast part of the Alluvial Plain and is joined southeast of Golddust by Jones Bayou, which heads near Ashport. Ultimately Cold Creek flows into The Chute, an abandoned channel of the Mississippi, north of Fort Pillow State Park.

\section{Drainage to Hatchie River}

The Hatchie River, a westward flowing stream, forms the southern boundary of Lauderdale county. Drainage to the Hatchie consists of Cane Creek which drains the uplands of the Coastal plain in the eastern, central, and southern parts of the county, and of many small southward flowing streams that drain the uplands in the southern part. The Hatchie is affected by backwater from the Mississippi River at least as far upstream as U.S. Highway 51 .

Cane Creek is by far the largest tributary of the Hatchie that originates in the county. This stream heads in the eastern part east of Ripley, flows westward passing north of Ripley, turns southward near Lightfoot, and enters the Hatchie south of Cherry. The principal tributary of Cane Creek is Hyde Creek, which heads southeast of Ripley, passes through south Ripley, and enters Cane Creek west of Ripley.

In recent years, Cane Creek has undergone channel modification to reduce floodwater and sediment damage under a project of the U.S. Soil Conservation Service. This project is sponsored by the Lauderdale County Soil Conservation District and Cane Creek Watershed District. In addition to land treatment measures by farmers, the work consists of channelization of the main channel and tributaries and the construction of many flood retarding structures in the basin. The estimated completion date of this project is 1981 . 
of the small southward flowing streams that drain southern parts of the county, the larger are cooper Springs Creek and its tributary Campground Creek east of Pleasant Hill and Camp Creek east of Orysa and Durhamville. Camp Creek flows into Lagoon Creek, which makes up the county's boundary at the southeast corner, and in turn flows into the Hatchie River.

\section{Drainage to South Fork Forked Deer River}

The South Fork Forked Deer River makes up the northeast boundary of Lauderdale county, flowing northward and passing east of Gates and Halls. Drainage to the South Fork is from Lost, Tisdale, Sumrow, and Mill Creeks, and Chambers Branch. These streams drain the uplands of the Coastal Plain in the northeastern parts of the county. The South Fork is affected by backwater from the Mississippi River at least as far upstream as the Illinois Central Railroad bridge north of Halls. The main channel and major tributaries have been channelized under past projects of the corps of Engineers.

Tisdale Creek heads near Curve and Dry Hill, flows northeastward through Gates, and as a result of channelization, joins Halls Creek southeast of Halls. A small segment of the lower reach of Tisdale still flows eastward into the South Fork. Sumrow Creek heads near Nankipoo, flows eastward, is joined by its principal tributary, Beech Bluff Creek, south of Halls, and becomes Halls Creek. Halls Creek originates from Sumrow and Tisdale creeks southeast of Halls and flows eastward into the South Fork.

Mills Creek heads in the uplands southeast of Porter Gap, flows eastward through Double Bridges, and enters the South Fork north of Halls. Chamber Branch drains the northernmost part of the county and enters the South Fork at the northeast corner. Lost Creek, which heads near Curve, drains a relatively small area of the uplands in the eastern part of the county.

\section{IMPACT OF STRIP-MINING ON THE HYDROLOGIC SYSTEM}

\section{General Considerations}

Strip-mining lignite in Lauderdale county could cause a variety of effects on the ground-water and surface-water systems. Major effects could result from the diseguilibrium created in the hydrologic system by extensive alterations of the land surface, redistribution of earth materials, and dewatering of mine sites.

For the ground-water system, the most obvious effects of strip-mining could be (1) an increase or decrease in hydraulic conductivities and recharge relations of the aquifers at the mine sites from the disturbance and mixing of aguifer and other earth materials, a lowering of water levels from pumping large quantities of water in dewatering, (3) a decrease in ground-water contribution to base flows in streams from lowering of water levels, and (4) a change in ground-water quality by the introduction of water of different quality into the aquifers from the mining operation. 
For the surface-water system, the most obvious effects of mining could be (1) modification of local drainage by diversion of stream channels in the vicinity of mine sites and construction of ditches and levees for drainage and flood protection, (2) changes in stream-flow characteristics and channel cross-section geometry from disposal of large guantities of water from dewatering, (3) an increase in sediment loads in streams from erosion of cleared land and displaced earth materials, and (4) a change in surface-water quality by the introduction of water of different quality into streams from the mining operation and dewatering activities.

Not knowing the location of any future strip mine or the specific methods by which mining would be conducted, many assumptions must be made in consideration of the impact of strip-mining on the hydrologic system. The following generalizations of strip-mining in the Mississippi Alluvial Plain and the Coastal Plain is intended to show conditions under which mining would occur in these geologically and topographically different areas.

\section{Mining in Mississippi Alluvial Plain}

Lignite in the Mississippi Alluvial Plain occurs in the Jackson and Cockfield Formations beneath the Mississippi alluvial deposits. Stripmining lignite in this area would require dewatering the alluvial deposits and part of the Jackson and Cockfield Formations and displacing large volumes of sand, gravel, silt, and clay that make up these geologic units. Overburden would range from about 100 to $150 \mathrm{ft}$ depending on the local thickness of the alluvial deposits, and mine depths could exceed 200 ft depending on the thickness of minable lignite. The Mississippi Alluvial plain lacks protection from floods on the Mississippi River so levees would be needed around mine sites for flood protection.

Water levels in the aquifers to be dewatered would be high because of the low altitudes of the Mississippi Alluvial Plain, and saturated thickness would include most of the depth to be excavated. The lower sand and gravel of the Mississippi alluvial deposits generally has a high hydraulic conductivity. Consequently, special techniques probably would be needed to dewater mine sites. For example, the slurry trench method used by the U.S. Army Corps of Engineers (1978) in the construction of the Huxtable Pumping Plant near Marianna, Ark., may have application in dewatering the alluvial deposits for lignite mining. In brief, this method consists of enclosing an excavation site with a trench filled with impermeable material to isolate the area to be dewatered from surrounding aguifers. The trench is dug to a depth necessary to intersect on impermeable clay, which restricts flow of water from below. The use of this method would minimize the effects of dewatering on the water levels in the surrounding aquifers.

Disposal of large quantities of water from dewatering would be into nearby streams or lakes. Water of different quality from dewatering and from oxidation and leaching of dewatered earth materials would cause changes in surface-water quality. 
Mining in Coastal Plain

Lignite in the Coastal Plain occurs in the Jackson and Cockfield Formations beneath the fluvial deposits and loess or alluvial deposits of the streams that drain the county. Strip-mining lignite in this area would require dewatering the fluvial deposits or alluvial deposits and part of the Jackson and Cockfield Formations and displacing large volumes of silt, sand, gravel, and clay that make up these geologic units. Overburden would range from about 0 to $150 \mathrm{ft}$ depending on the mine-site geology, and mine depths could be as much as $200 \mathrm{ft}$ depending on the thickness of minable lignite. The loess, which is primarily silt, is highly susceptible to erosion where denuded of vegetation and disturbed by excavation so erosion control would be needed to minimize sediment contribution to streams.

Water levels in the aquifers to be dewatered would depend largely on topograpic position of mine sites. In general, water levels in respect to land surface are shallow beneath the valleys and deep beneath the hills. Saturated thicknesses and hydraulic conductivities would depend on the local water levels and geology of the aquifers at the mine sites. The fluvial deposits locally are disconnected and function independently, and at these places, this aquifer could be virtually "dried up" from dewatering of mine sites. Dewatering of the Jackson and Cockfield Formations would reduce water levels updip and downdip from mine sites.

Large quantities of water from dewatering would be disposed of in streams draining basins in which mines are located. This water would change the stream-flow characteristics and surface-water guality and could change the channel cross-section geometry. In addition, the dewatering of mine sites and the displacement and redistribution of overburden would expose large volumes of earth materials to oxidation and leaching, and mineralized water from these materials would cause changes in ground-water and surface-water quality.

\section{NEEDS FOR HYDROLOGIC INFORMATION AND PROPOSED DATA COLLECTION ACTIVITIES}

\section{Surface Geologic Maps}

The latest geologic map that covers the county is the "Geologic Map of Tennessee" (scale 1:250,000) by Hardeman and others (1966, west sheet). This map is very generalized and is limited in usefulness to regional aspects of the geologic units. Detailed geologic maps (scale $1: 62,500$ ) by Saucier and others (1964-78) are available for the Mississippi Alluvial plain. These maps include features of fluvial deposition and are adeguate for most purposes, but do not include the geology of the Coastal plain areas.

It is proposed that detailed geologic maps for Lauderdale County be prepared on 7.5-minute topographic quadrangles (scale 1:24,000) for those maps that include Coastal Plain areas. These geologic maps would provide a description of the local geology on a quadrangle-by-quadrangle basis and would meet most requirements for general information concerning the surface geologic formations. 
Of the 20 topographic quadrangles (7.5-minute) that cover the county, the 15 that include Coastal Plain areas are:

$\begin{array}{lll}\text { Knob creek } & \text { Gates } & \text { Durhamville } \\ \text { Fowlkes } & \text { Chestnut Bluff } & \text { Nodena } \\ \text { Bonicord } & \text { Golddust } & \text { Gilt Edge } \\ \text { Open Lake } & \text { Ft. Pillow } & \text { Gift } \\ \text { Ripley North } & \text { Ripley South } & \text { Turnpike }\end{array}$

Priorities may be set on certain maps based on the size of the Coastal plain area and the likelihood of mining within a particular quadrangle area.

An optional proposal is the preparation of geologic maps on available 15-minute topographic quadrangles for those maps that include Coastal Plain areas. Because of the relatively uncomplicated surface geology and the immediate need for geologic information, the preparation of less detailed maps may be justified. Nevertheless, completion of 15-minute geologic maps for publication would require mapping larger areas of adjacent counties than would be necessary for 7.5-minute maps. Most of the Coastal Plain of Lauderdale county is included on four 15-minute quadrangles as follows:

\author{
Hales Point Osceola \\ Halls Rialto \\ Ground-water Information
}

The shallow aquifers--Mississippi alluvial deposits, fluvial deposits, and Jackson and Cockfield Formations--provide water to the majority of wells in Lauderdale county and supply the greatest variety of uses. These wells are generally less than $300 \mathrm{ft}$ deep. Specific information concerning existing water wells, subsurface stratigraphy, water-level trends and configurations, aquifer characteristics, and ground-water guality is needed inasmuch as the shallow aguifers would be most affected by any future strip-mining of lignite. Of the shallow aquifers, the Jackson and Cockfield Formations are by far the most extensively used.

\title{
Water-well Inventory
}

The Geological Survey has records for about 50 wells drilled in Lauderdale County prior to 1966, and the TDWR has records for about 600 wells drilled since 1963. Maximum use of these records is greatly hindered because of inadequate or inaccurate locations and lack of landsurface altitudes. In addition to these wells, many others are suspected to exist for which no records are on file. A comprehensive water-well inventory is needed for (1) appraising the ground-water resource, (2) locating wells with potential for use in collecting hydrologic and geologic data, (3) assessing any future damage to ground-water supplies that might result from mining activities, and (4) planning alternative supplies for areas that might be affected by mining.

It is proposed that a comprehensive water-well inventory be made for the county. Emphasis would be placed on a complete inventory of wells used for public, industrial, commercial, and irrigational supplies. The 
records of wells on file with the Geological Survey and TDWR would provide the basis for beginning this inventory. Inventoried wells would be located on the twenty $71 / 2$ minute topographic guadrangles that cover the county. An effort would be made to locate the wells to an accuracy of about 50 feet horizontal distance on the maps so that usable altitudes of the land surface at the well sites can be interpolated. Location to this accuracy could be facilitated by using aerial photographs of the same approximate scale along with the topographic quadrangles reproduced on clear base-stable materials for overlaying.

Many owners of known wells would be interviewed for information concerning other wells in the vicinity. For wells for which no records are on file, owners would be asked to supply pertinent information for later use in contacting the water-well contractors to obtain these records. Basically, this information would consist of (1) present or previous owner when the well was drilled, (2) water-well contractor who drilled the well, (3) year the well was drilled, and (4) diameter and depth of the well, if known. As the inventory of each quadrangle is completed, the water-well contractors would be contacted and asked to provide the needed records, if available.

Special attention would be given the location of unused or abandoned wells with potential for use in monitoring water levels or in making geophysical logs. During the inventory, water levels would be measured in wells that are accessible for this purpose. For these wells, depth to water, date of measurement, description of the measuring point, and vertical distance to the nearest tenth of a foot of the measuring point above land surface would be recorded.

Well data collected during this inventory would be coded and entered into the Geological Survey or TDWR computer systems for storage and retrieval. The inventory would be kept up-to-date by periodically locating new wells as records are submitted to the TDWR by water-well contractors. These additional well records then would be added to the computer system.

\section{Subsurface Stratigraphy}

The subsurface stratigraphy of the shallow aquifers is known only in very general terms. Information is needed concerning the variability of the lithology and thickness of these aquifers and the depth to the base of and occurrence of 1 ignite in the Jackson and cockfield Formations.

It is proposed that 12 test holes be drilled at selected sites for stratigraphic information. Nine of these test holes would be drilled through the Mississippi alluvial deposits or fluvial deposits, through the Jackson and Cockfield Formations, and into the underlying Cook Mountain Formation. Two test holes would be drilled through the Mississippi alluvial deposits into the Jackson and Cockfield Formations, and one test hole would be drilled through the fluvial deposits into the Jackson and Cockfield Formations.

In drilling the test holes, samples of cuttings would be collected at 10-ft intervals and a driller's log would be kept for compiling detailed descriptive logs for each well. Geophysical logs--resistance, spontaneous 
potential, gamma-ray, and gamma-gamma--would be made to provide supplemental information on lithology and thickness of the aquifers and a graphical record of each well for compiling cross-sections, and so forth. The gamma-gamma log would provide information on bulk densities, which is important in the recognition of 1 ignite beds. The resistance and gammaray logs along with sand samples would provide a basis on which to select screen intervals for observation wells.

Table 6 is a list of the proposed stratigraphic test holes, and figure 14 shows their tentative locations. Prediction of the total depth for each test hole is very approximate because of the limited information as to the depth to the base of the Jackson and Cockfield Formations and the lack of knowledge as to the land-surface altitudes at the final drilling sites.

Water-Level Trends and Configurations

The only water-level data available for the shallow aguifers in Lauderdale county are miscellaneous measurements made for previous studies by the Geological survey and water levels reported on driller's records filed with the TDWR. Inasmuch as extensive areas would have to be dewatered in conjunction with any future strip-mining of lignite, baseline information is needed on water-level trends and configurations in the shallow aguifers--particularly in the Mississippi alluvial deposits and Jackson and Cockfield Formations.

It is proposed that the 12 test holes drilled for stratigraphic information be completed as observation wells--two in the Mississippi alluvial deposits, one in the fluvial deposits, and nine in the Jackson and cockfield Formations. The observation wells would be cased from land surface down to the screen and would be screened in a suitable sand or sand and gravel in the selected aquifers. Shelters and digital records would be installed on five observations wells for the collection of continual records. The digital recorders would be geared to provide water levels on an hourly basis. Service of recorders and tape measurements would be at 4 to 6 week. intervals, and the data would be processed using computer techniques. The observation wells without recorders would be sealed at their tops with provision made for making monthly tape measurements.

Table 6 gives the approximate depth of the proposed observation wells, and figure 14 shows their tentative locations. The depths given are very approximate because of the lack of stratigraphic information to be provided by the test holes. Many of the observation wells possibly could be completed at shallower depths than those indicated. The site of well 9 would be located adjacent to an observation well in the Jackson and cockfield Formations, but its final location may depend on the drilling of several test holes in the Coastal plain to find satisfactory sand and gravel in which to screen an observation well in the fluvial deposits. well 8 would be located adjacent to the existing observation well in the Memphis Sand at the Fort Pillow State Historic Area.

A recorder would be installed on well 2 to determine water-level trends in the Mississippi alluvial deposits and any water-level response to changes in stage on the Mississippi River. Recorders would be 
Table 6.--Proposed stratigraphic test holes and observation wells in Lauderdale county (See figure 14 for locations)

\begin{tabular}{|c|c|c|c|c|c|c|}
\hline $\begin{array}{l}\text { Well } \\
\text { number }\end{array}$ & $\begin{array}{l}7.5 \text {-minute } \\
\text { topographic } \\
\text { guadrangle }\end{array}$ & $\begin{array}{l}\text { Tentative } \\
\text { location }\end{array}$ & $\begin{array}{l}\text { Approximate } \\
\text { altitude } \\
\text { (ft above } \\
\text { mean sea } \\
\text { level) } \\
\end{array}$ & $\begin{array}{c}\text { Estimated } \\
\text { depth of } \\
\text { stratigraphic } \\
\text { test hole } \\
\text { (ft) }\end{array}$ & $\begin{array}{l}\text { Estimated } \\
\text { depth of } \\
\text { observation } \\
\left.\text { well }{ }^{2} \text { ( } f t\right)\end{array}$ & $\begin{array}{c}\text { Aguifer for } \\
\text { observation } \\
\text { well } \\
\text { completion }\end{array}$ \\
\hline 1 & Chic & near Hales Point & 260 & 450 & 400 & Tjc \\
\hline 2 & Knob Creek & W. of Knob Creek & 250 & 100 & 70 & Qal \\
\hline 3 & Fowlkes & near Poplar Grove & 390 & 500 & 470 & $\mathrm{Tj} \mathrm{C}$ \\
\hline 4 & Rosa & near Ashport & 250 & 350 & 320 & $\mathrm{Tjc}$ \\
\hline 5 & Ripley North & near Central & 490 & 550 & 500 & TjC \\
\hline 6 & Chestnut Bluff & E. of Gates & 280 & 220 & 150 & $\mathrm{Tjc}$ \\
\hline 7 & Golddust & S. of Ashport & 250 & 120 & 80 & Qal \\
\hline 8 & Golddust & $\begin{array}{l}\text { Ft. Pillow State } \\
\text { Historic Area }\end{array}$ & 440 & 420 & 370 & $\mathrm{Tjc}$ \\
\hline 9 & Ft. Pillow & near Glimp & 380 & 100 & 90 & QTf \\
\hline 10 & Ft. Pillow & near Glimp & 380 & 370 & 350 & $\mathrm{Tjc}$ \\
\hline 11 & Ripley South & SE of Henning & 310 & 200 & 180 & $\mathrm{Tjc}$ \\
\hline 12 & Durhamville & E. of Ripley & 470 & 400 & 370 & $T j c$ \\
\hline
\end{tabular}

\footnotetext{
Estimated total footage of stratigraphic test holes is $3,780 \mathrm{ft}$.

${ }^{2}$ Estimated total footage of cased and screened observation wells is $3,350 \mathrm{ft}$.

${ }^{3}$ Qal - Missississi alluvial deposits, QTf - Fluvial deposits, Tjc - Jackson and Cockfield Formations.
} 


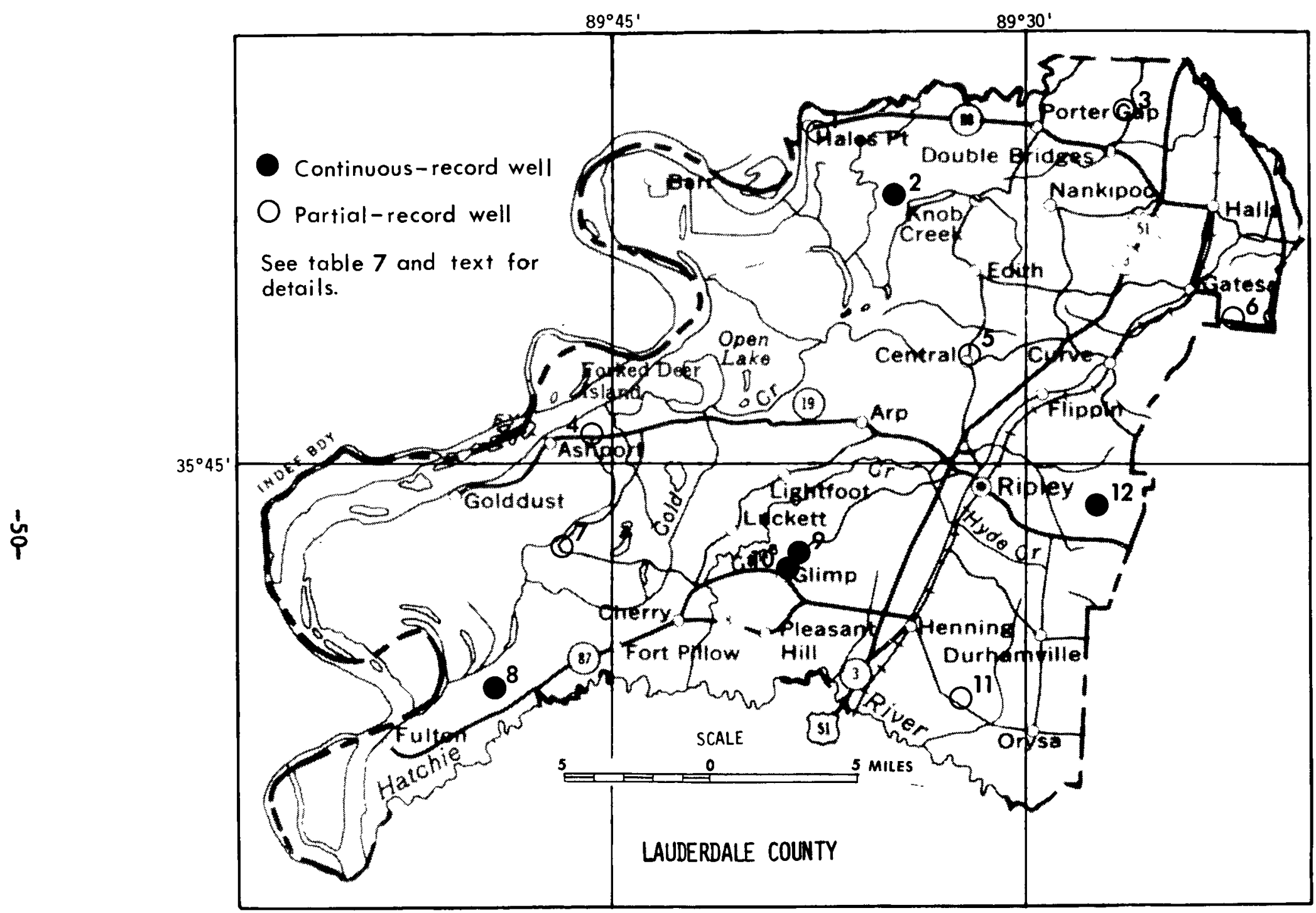

Figure 14.--Tentative locations of proposed stratigraphic test holes and observation wells. 
installed on wells 9 and 10 (tentative companion well, see above) to determine water-level trends in the fluvial deposits and Jackson and Cockfield Formations, and to provide a basis of comparison of water levels in these two aguifers. A recorder would be installed on well 8 for a basis of comparison of the water levels in the Jackson and Cockfield Formations and those in the Memphis Sand and to determine any water-level response in the Jackson and Cockfield Formations to changes in stage on the Mississippi River. A recorder would be installed on well 12 to detemine water-level trends in the Jackson and Cockfield Formations in an area away from pumping and the Mississippi River.

Optional work proposed is the making of water-level measurements in observation wells and selected water wells at times of high and low water levels for the purpose of drawing potentiometric-surface maps of the Mississippi alluvial deposits and the Jackson and Cockfield Formations. Success of this work would depend on the cooperation of well owners and accessibility into the well casing for taping water levels.

\section{Aquifer Characteristics}

Aguifer-test results are available for only one well in the Jackson and Cockfield Formations at the U.S. Military Reservation near Halls. Values for transmissivity and storage for this aguifer were determined from this test. Determination of the aquifer characteristics of the shallow aquifers is needed for predicting the effects of dewatering on water levels in the aquifers and for calculating the rate of movement of contaminants from any future strip-mining activity.

It is proposed that single-well pumping tests be performed in each of the 12 wells completed as observation wells to obtain values of transmissivity. To perform these tests, the observation wells would have to be properly constructed and developed to give reliable pump-test results. The wells would have to be at least 6 in. in diameter to allow the installation of a portable pump capable of pumping at least $100 \mathrm{gal} / \mathrm{min}$. The screens would have to be about $20 \mathrm{ft}$ in length, depending on the slot size selected to screen a particular sand. Residual drilling mud would have to be pumped from the well and flushed from the formation surrounding the screen by using well development techniques. The portable pump would be installed and pumped at a constant rate for a period of no less than 4 hours. A provision would have to be made for measuring water levels with the pump installed. Recovery data is important in single-well pumping tests so the necessary water-level measurements would have to be made during the pumping period and also during the recovery period.

To obtain values of coefficient of storage, small diameter of fset wells would have to be drilled at specified distances from the pumped wells for additional water level measurements. It is proposed that, if undertaken, this work would be limited to about three of the sites with observation wells in the Jackson and Cockfield Formations. These offset wells also would have to be cased and screened in the sand to be pumped. Data for proposed offset wells is not included in table 6 .

Additional data on the hydrologic characteristics of the aquifers and their confining beds could be derived by monitoring water levels in both wells during pumping tests at sites where two wells are screened in different aquifers. 


\section{Ground-water Quality}

Available analyses of ground water from wells in Lauderdale County include 12 samples from the shallow aquifers--six from the Mississippi alluvial deposits, two from the fluvial deposits, and four from the Jackson and Cockfield Formations (table 4). These analyses were made between 1929 and 1956.

Ground-water quality changes little with time except in heavily pumped areas where water of different quality may enter as replenishment of water removed. Nevertheless, monitoring changes in ground-water quality is essential in determining the effects of any future strip-mining activity, particularly where extensive areas are to be dewatered. Additional baseline information is needed on the quality of ground water from the shallow aquifers, using modern methods of sampling and analytical procedures and including data on trace metals and organic compounds.

It is proposed that the 12 wells completed as observation wells be sampled for water guality near the conclusion of each pumping test. The water samples would be collected using Geological Survey procedures and analyzed in the Survey's laboratories. Water-quality paramaters to be determined are 1 isted below:

Field measurements of water-quality parameters:

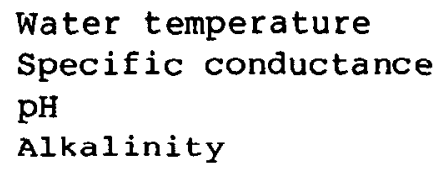

Laboratory analyses of dissolved major constitutents:

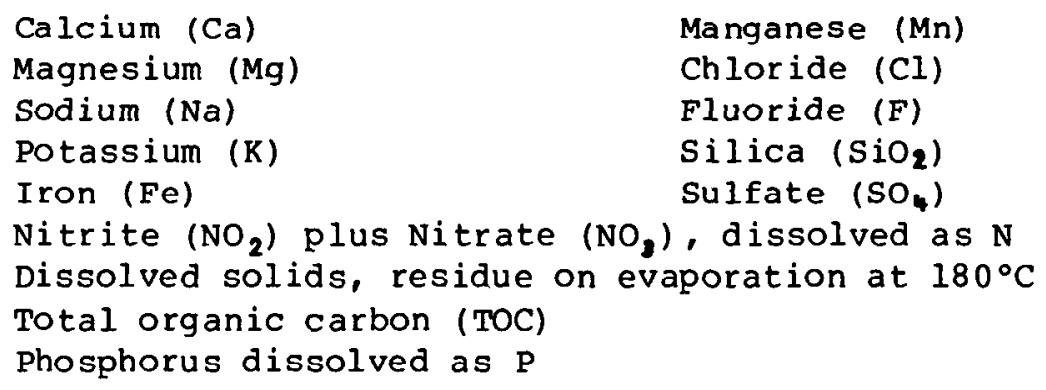

It also is proposed that two wells--well 7 in the Mississippi alluvial deposits and well 5 in the Jackson and Cockfield Formations (table 6)--be completed with pumps for the collection of monthly water 
samples for a period of one year to determine whether short-term changes in ground-water quality occur. After the first year these wells would be sampled twice-a-year, at times of low and high water levels to determine long-term changes in water guality. In installing pumps, provision would be needed to allow monthly tape measurements in these wells. The water samples would be analyzed according to the above ground-water parameters.

\section{Surface-water Information}

Strip-mining lignite in Lauderdale County could cause significant changes in the surface-water system in those basins in which mining occurs. Therefore, baseline information is needed on the stream-flow characteristics and surface-water guality of the major streams that drain the county. Rainfall data is also needed in determining rainfall-runoff relationships.

\section{Stream-flow Characteristics}

Except for data for the discontinued gaging station on Cane Creek at Ripley and some discharge measurements at miscellaneous sites, little surface-water information is being collected for the streams that drain the county. Speer and others (1965, table 2) gave the low-flow characteristics for Cane Creek at Ripley, Cane Creek near Cherry, and cold Creek at Arp (table 5). Since the gaging station on Cane Creek at Ripley was discontinued, changes in the stream-flow characteristics have occurred as a result of the U.S. Soil Conservation Service's project to reduce floodwater and sediment damage. Presently, the only stream-flow data being collected for the tributary streams are once-a-year low-flow measurements on Cane Creek near Cherry.

It is proposed that 13 partial-record and 4 continuous-record gaging stations be established at 17 sites--12 in the Coastal Plain and 5 in the Mississippi Alluvial Plain--to provide data on the stream-flow characteristics of the major streams. At the partial-record stations, discharge measurements would be made three times a year at low, medium, and high flows. The continuous-record gaging stations would be equipped with shelters, bubble gages, and digital recorders geared to provide stage at 5-minute intervals. These stations, located on selected streams of different basin sizes and topographical characteristics, would provide the information needed for correlation and rating of the partial-record stations. Servicing of recorders would be monthly at which times discharge measurements would be made. Additional discharge measurements would be made at low, medium, and high flows. The data from the digital recorders would be processed using computer techniques.

Table 7 lists the proposed partial-record and continuous-record gaging stations, and figure 15 shows their tentative locations. The sites proposed were selected from 7.5-minute topographic quadrangles and must be evaluated as to suitability by field investigation. 
Table 7.--Proposed stream-flow gaging stations and surface-water data collection sites in Lauderdale County [See figure 15 for locations]

\begin{tabular}{|c|c|c|c|}
\hline $\begin{array}{c}\text { Site } \\
\text { number }\end{array}$ & $\begin{array}{l}\text { 7.5-minute } \\
\text { topographic } \\
\text { quadrangle }\end{array}$ & Tentative location & $\begin{array}{l}\text { Proposed data } \\
\text { collection } \\
\text { activities }\end{array}$ \\
\hline \multicolumn{4}{|c|}{ Drainage to Mississippi River } \\
\hline 1 & Knob Creek & old Bed Forked Deer River near Knob Creek & PR, QW, S \\
\hline 2 & Knob Creek & Knob Creek at Knob Creek & $P R, Q W, S$ \\
\hline 3 & Ripley North & Cold creek (north) near Arp & $C R, Q W, S, R G$ \\
\hline 4 & Open Lake & Middle Fork Forked Deer River near Arp & PR, QW, S \\
\hline 5 & Ft. Pillow & Cold Creek (south) near Olive Branch & $P R, Q W, S$ \\
\hline 6 & Golddust & Jones Bayou near Golddust & $\mathrm{PR}, \mathrm{QW}, \mathrm{S}$ \\
\hline 7 & Golddust & Cold Creek (south) near Fulton & $P R, Q W, S$ \\
\hline \multicolumn{4}{|c|}{ Drainage to Hatchie River } \\
\hline 8 & Ripley North & Cane Creek at Ripley (north) & $P R, Q W, S$ \\
\hline 9 & Ripley south & Hyde Creek at Ripley & $P R, Q W, S$ \\
\hline 10 & Ripley North & Cane Creek near Ripley (west) & $P R, Q W, S$ \\
\hline 11 & Ft. Pillow & Cane Creek near Cherry & $C R, Q W, S, R G$ \\
\hline 12 & Ft. Pillow & Cooper Springs Creek near Pleasant Hill & $P R, Q W, S$ \\
\hline 13 & Ripley south & Hatchie tributary near Henning & $P R, Q W, S$ \\
\hline 14 & Gift & Hatchie tributary near Orysa & $P R, Q W, S$ \\
\hline \multirow[t]{2}{*}{15} & Turnpike & Camp Creek at Orysa & $C R, Q W, S R G$ \\
\hline & \multicolumn{3}{|c|}{ Drainage to South Fork Forked Deer River } \\
\hline 16 & Fowlkes & Mill Creek near Halls & PR, QW, S \\
\hline 17 & Chestnut Bluff & Halls Creek near Chestnut Bluff & $C R, Q W, S, R G$ \\
\hline
\end{tabular}

1 PR - partial-record station, CR - continuous-record station, QW - quality of water sample, $\mathrm{S}$ - sediment sample, $\mathrm{RG}$ - rainfall gage. 


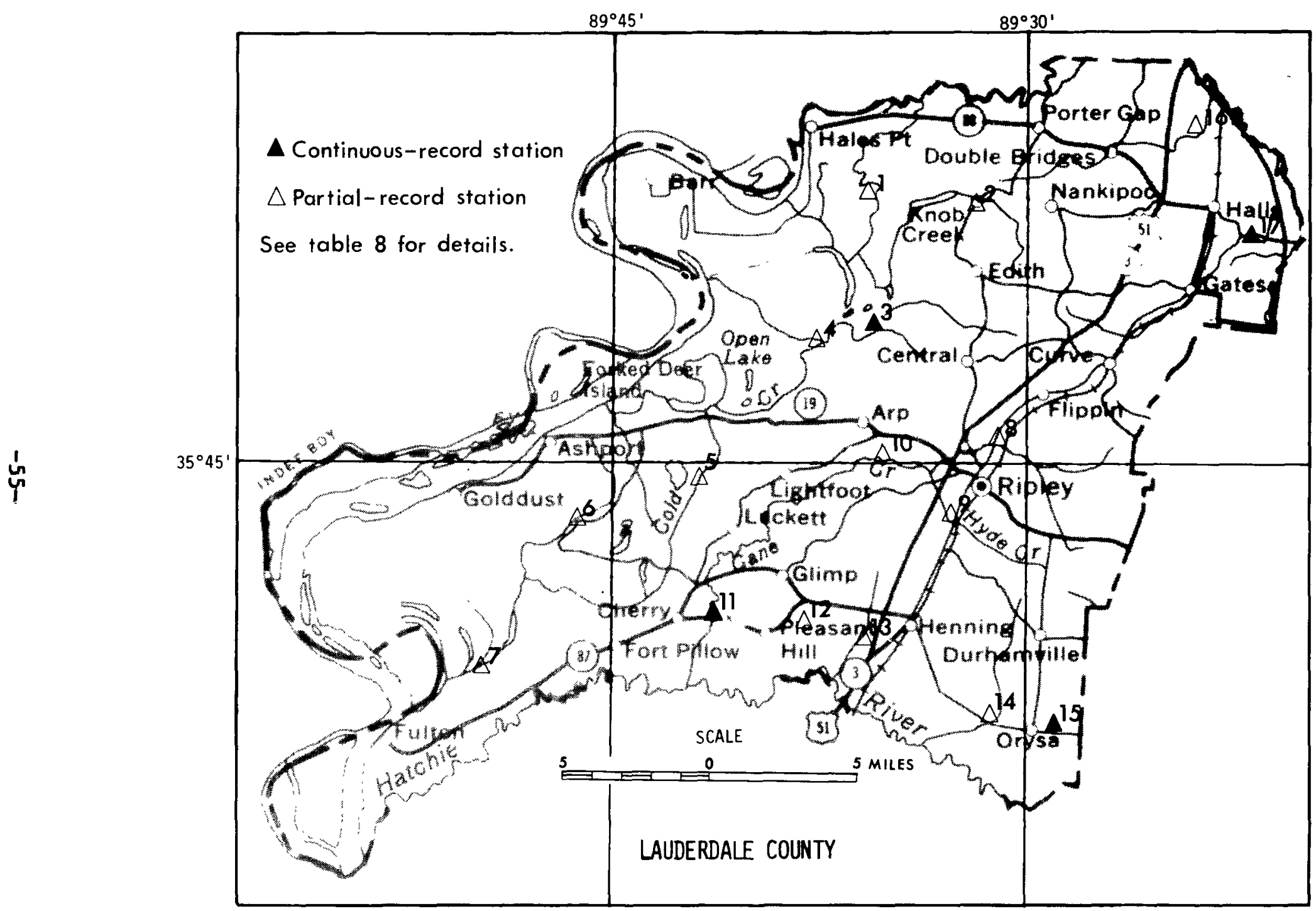

Figure 15.--Tentative locations of proposed stream-flow gaging stations and surface-water data collection sites. 


\section{Surface-water Quality}

Very limited data are available concerning the surface-water quality in Lauderdale County. A few measurements of water temperature and specific conductance have been made in conjunction with discharge measurements on Cane Creek at Ripley and Cane Creek at Cherry. Table 8 gives sediment data collected for the Hatchie River at Rialto.

Surface-water quality changes with time in relation to amount of discharge, season of the year, and man-made changes in the basin, and data must be collected over a period of time to establish water-quality characteristics of a particular stream. Any future strip-mining of lignite would affect the surface-water quality in those basins where mining takes place. Therefore, it is essential to collect baseline information on surface-water quality of the major streams that drain the county before mining begins.

It is proposed that water-quality parameters be measured at each of the 17 partial or continuous-record stations. The parameters that would be measured are basically those selected as mandatory or suggested for the Geological Survey's coal hydrology program in support of Public Law 95-87 (F. A. Kilpatrick, written commun., 1979). At each station a discharge measurement and water sample for on site and laboratory analysis would be collected at low, medium, and high flows each year. Bed material samples for particle size analysis would also be taken during these low, medium, and high flows. These particle size analyses would be used in conjunction with hydraulic data to compute bed-load transport rates.

The bed material samples taken at all stations once-a year during low flow would also be analyzed for minor elements. In addition, water samples would be taken at continuous record stations once-a-year during low flow for analyses of common constituents and minor elements. Waterquality parameters to be determined are listed below.

Water quality of surface-water for partial and continuousrecord stations, measured on site three times a year at low, medium, and high flows:

Discharge

Water temperature

Specific conductance

$\mathrm{pH}$

Alkalinity

Macro-invertebrates (presence or absence at low flow)

Laboratory analyses of water quality for partial- and continuousrecord stations, sampled three times a year at low, medium, and high flows. 
Table 8.--Sediment data collected for the Hatchie River at Rialto

[Station number 07030050 ]

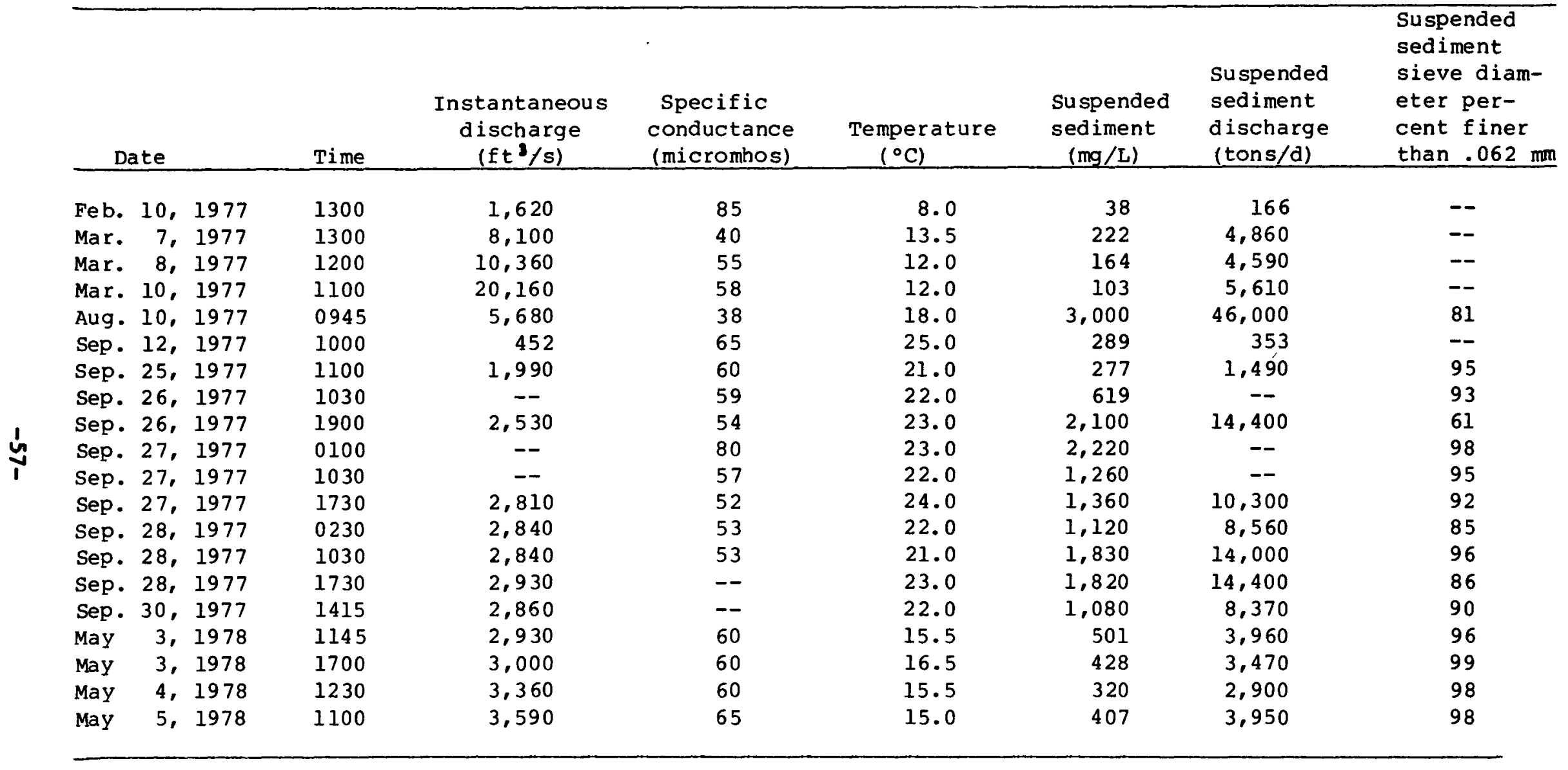




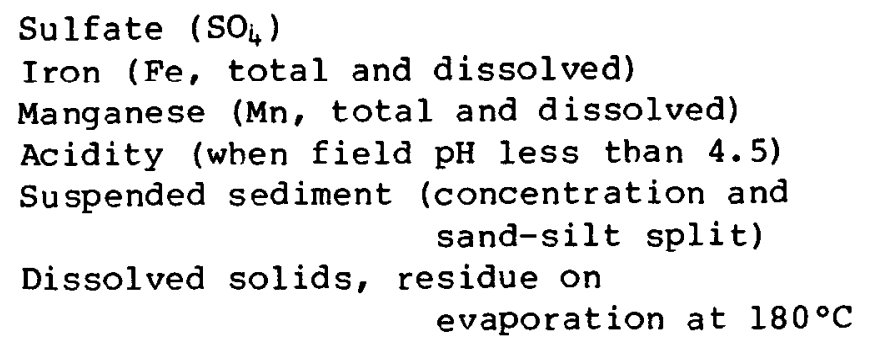

Laboratory analyses of bed materials for partial- and continuousrecord stations, sampled annually at low flow:

$\begin{array}{ll}\text { Arsenic (As) } & \text { Lead (Pb) } \\ \text { Cadmium (Cd) } & \text { Manganese (Mn) } \\ \text { Chromium (Cr) } & \text { Mercury (Hg) } \\ \text { Copper (Cu) } & \text { Selenium (Se) } \\ \text { Iron (Fe) } & \text { Zinc (Zn) }\end{array}$

Laboratory analyses of water quality for continuous-record stations, sampled annually at low flow:

Common constituents (dissolved)

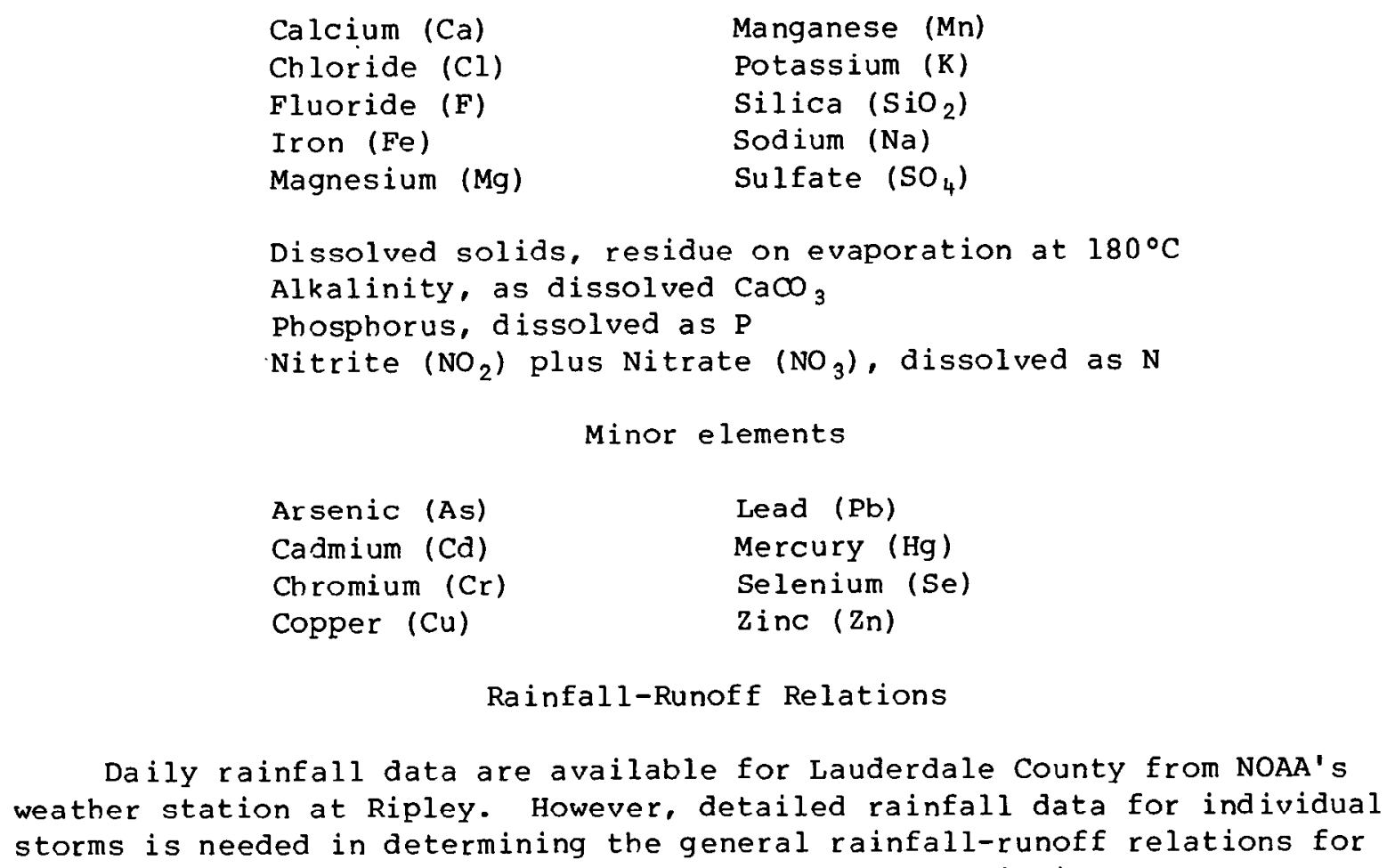

Rainfall-Runoff Relations

Daily rainfall data are available for Lauderdale County from NOAA's weather station at Ripley. However, detailed rainfall data for individual storms is needed in determining the general rainfall-runoff relations for basins of different sizes and topographical characteristics. 
It is proposed that recording rainfall gages be established at each of the four continuous-record gaging stations. Shelters, rainfall gages, and digital recorders would be installed with the digital recorders geared to record rainfall at 5-minute intervals. Servicing of recorders would be conducted monthly along with the recorders on the stream-flow gages. The data from the digital recorders would be processed using computer techniques.

\section{PLANS TO MONITOR STRI P-MINING OF LIGNITE}

\section{Collection of Mine-Site Data}

At the time an announcement is made that a strip mine for lignite is to be opened, a plan should be ready for collection of mine-site data so that premining, mining, and postmining hydrologic conditions can be determined for the basin(s) in which mining will take place. This plan would need to be implemented soon after an announcement so that baseline information could be collected prior to the clearing of land, disturbance of the land surface, and dewatering of aquifers. Monitoring the effects of mining would be for the duration of the mining activity and extend beyond reclamation to determine any delayed or lasting effects on the hydraulic system.

Figure 16 is a schematic diagram of a generalized basin with surface mine and proposed sites for hydrologic monitoring (Dalsin, 1979, fig 8). Not knowing the location of any future strip mine, this plan would need to be modified to take into account local hydrologic conditions of the particular basins(s) in which mining will take place. For example, monitoring hydrologic conditions in the Mississippi Alluvial plain may require a somewhat different approach than monitoring those in the Coastal Plain.

Basically, the plan for collection of ground-water data would consist of the installation of six observation wells--two wells in three sets with wells in each set in two different aquifers. A minimum of three observation wells per aquifer would be needed to determine changes in the gradient of ground-water movement. In the coastal Plain, one well in each set would be in the fluvial deposits and the other would be in the Jackson and Cockfield Formations, and in the Mississippi Alluvial Plain one well would be in the Mississippi alluvial deposits and the other would be in the Jackson and Cockfield Formations.

These observation wells would be drilled to meet the specifications proposed elsewhere in this report for construction of observation wells for baseline information. In brief, formation samples would be taken at 10-ft intervals during drilling; geophysical logs would be run in the uncased boreholes; single-well pumping tests would be conducted in the cased wells; and water samples would be collected near the conclusion of the pumping tests for ground-water quality determinations. The groundwater-quality parameters would be the same as those listed on page 52 for baseline information. Digital recorders would be installed on one set of wells for the collection of continuous water level data, and provision would be made for periodic taping of water levels in the other two sets of wells. After initial sampling for ground-water quality, additional samples would be collected for analysis twice-a-year at times of $\mathrm{bigh}$ and low water levels. 


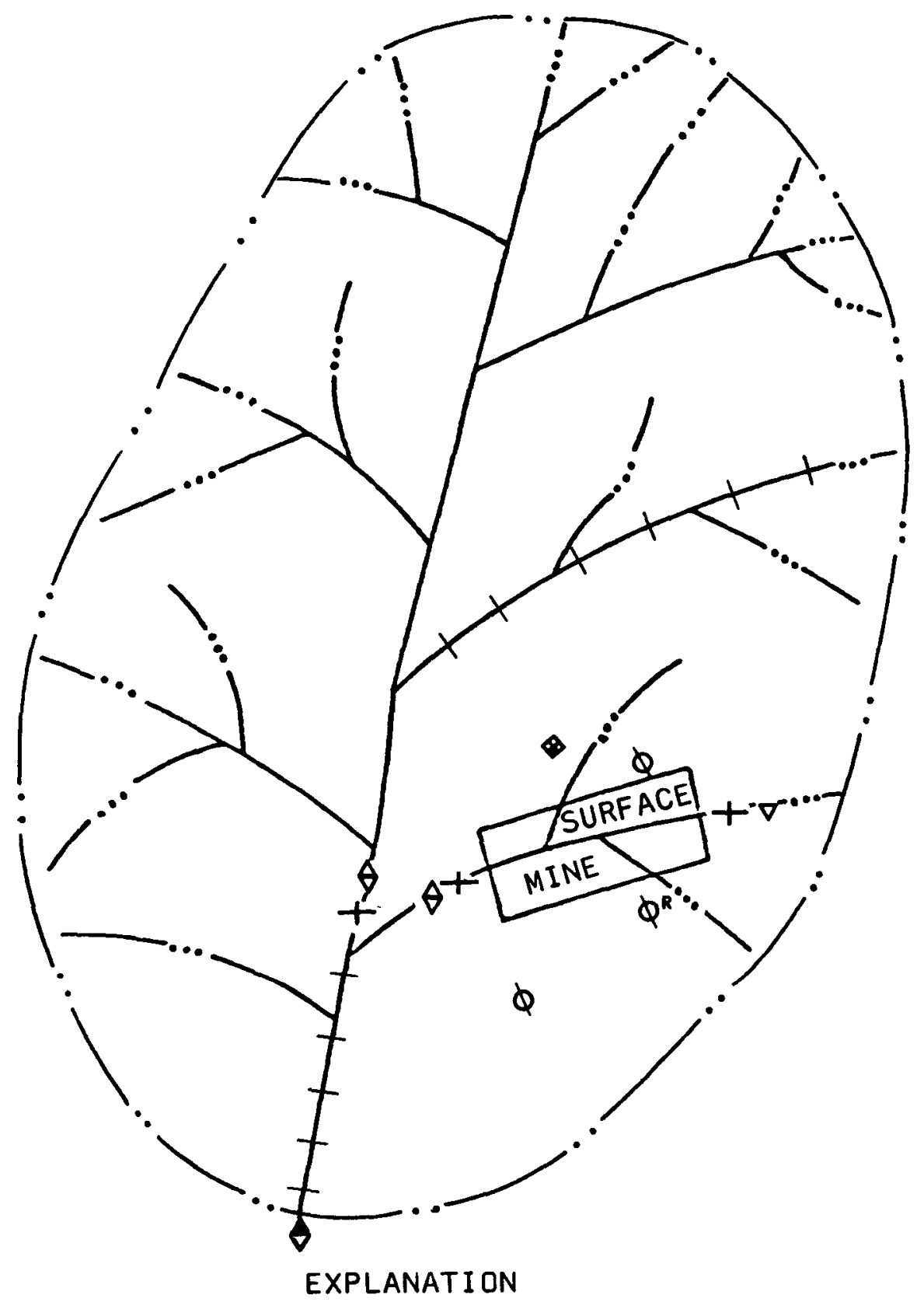

- Continuous streamflow gaging station

Q Observation well set

$Q^{R}$ Observation well set equipped with recorders

$\nabla$ Water-quality monitor and sediment sampler

$\forall$ Water-quality survey and seepage measurement site

+ Channel cross-section survey

- Rain gage

- Drainage basin boundary

Figure 16.--Generalized drainage basin with surface mine and proposed sites for hydrologic monitoring (from Dalsin, 1979, fig. 8). 
The plan for collection of surface-water data would consist of the installation at two outflow sites downstream from the strip mine of: (1) a continuous-record stream-flow gaging station, (2) a surface-water guality monitor, and (3) an automatic suspended-sediment sampler. A recording rain gage also would be installed near the mine site. The continuousrecord gaging stations would be equipped with digital recorders and bubble gages, and discharge measurements would be made montbly. The surface-water quality monitors would be equipped to measure temperature, specific conductance, $\mathrm{pH}$, and dissolved oxygen on a continuous basis. Additional water-quality parameters would be determined for these sites in accordance with those listed on pages 56 and 58 for continuous-record gaging stations. The automatic samplers for suspended sediment would sample twice daily and more frequently during rainfalls. Photographs of the channel and cross-section measurements would be made at the gaging station reach to record changes in channel degradation or siltation.

Other data collection activities would include surface-water quality surveys, seepage measurements, and monumented channel cross-section surveys conducted upstream and downstream from the mine site. The surfacewater quality surveys would be conducted monthly, and the parameters determined would be those listed for partial record gaging stations listed on pages 56 and 58. Seepage measurements and channel cross-section surveys would be conducted annually at low flow.

\section{Application of Computer Modeling Techniques}

After several years of baseline data collection in accordance with the plan proposed in this report, sufficient data would be available for the application of computer modeling techniques. Computer modeling of the ground-water and surface-water systems would be a highly desirable tool for analyzing and interpreting large amounts of data and in predicting the effects of mining on the hydrologic system. The Geological Survey has developed several digital models that would be adaptable for this purpose. Because of the sophistication of computer modeling, a detailed proposal would be needed for this activity, which is beyond the scope of this project.

\section{SUMMARY OF PLAN TO STUDY HYDROLOGY}

Although some information is available on the geology and hydrology of Lauderdale County, much additional information is needed to define the hydrologic system before mining begins, and a plan is needed to monitor the effects of mining on the hydrologic system once it is begun. For general geologic information, it is proposed that geologic maps be prepared for the Coastal Plain areas of the county on either 7.5- or 15-minute topographic quandrangles.

For ground water, information is needed on the location of existing water wells, subsurface stratigraphy, water-level trends and configurations, aquifer characteristics, and ground-water quality of the shallow aquifers--Mississippi alluvial deposits, fluvial deposits, and Jackson and 
Cockfield Formations. These shallow aquifers, which provide water to the mejority of wells in the county and supply the largest variety of uses, would be the most affected by strip-mining and dewatering activities. The Jackson and Cockfield Formations are by far the most extensively used of the shallow aquifers.

It is proposed that a comprehensive water-well inventory be made for the county and that 12 test holes be drilled for stratigraphic information. The stratigraphic information would include the variability of the lithology and thickness of the shallow aguifers and the depth to the base and occurence of lignite in the: Jackson and Cockfield Formations. The 12 stratigraphic test holes would be completed as observation wells--two in the Mississippi alluvial deposits, one in the fluvial deposits, and nine in the Jackson and Cockfield Formations. Single-well pumping tests would be conducted to determine values of transmissivity. Near the conclusion of the pumping tests, water samples would be collected for determination of ground-water quality, including common constituents and minor elements. Recorders would be installed on five observation wells for the collection of continual water-level data for the shallow aquifers, and the other wells would be tape measured monthly. Two wells--one in the Mississippi a.lluvial deposits and the other in the Jackson and Cockfield Formations-would be sampled monthly for one year to provide data on short-term changes in ground-water quality. After the first year, these well would be sampled twice-a-year at times of low and high water levels to determine long-term changes in ground-water quality. Optional work proposed includes the drilling of offset wells near some observation wells for measuring water levels during pumping tests to determine values of coefficient of storage. Also optional would be the twice-a-year measurement of water levels in observation wells and selected water wells at times of high and low water levels for use in drawing potentiometric-surface maps for the Mississippi alluvial deposits and the Jackson and cockfield Formations.

For surface-water, information is needed on the stream-flow characteristics, surface-water quality, and rainfall-runoff relations of the streams that drain the county. Strip-mining of lignite could cause significant changes in the surface-water system in those basins in which mining occurs. It is proposed that 13 partial-record and 4 continuous-record stream-flow gaging stations be established on the major streams that drain the county --12 in the Coastal Plain and 5 in the Mississippi Alluvial plain. At partial-record stations, a discharge measurement would be made each year at low, medium, and high flows. At continuous-record stations, discharge measurements would be made monthly at the time recorders are serviced and also once-a-year at low, medium, and high flows. At all stations on site surface-water quality parameters would be measured and water samples for analysis of selected constituents and suspended sediment and bed material for particle-size analysis would be collected once-a-year at low, medium, and high flows when discharge measurements are made. Also at all stations, bed materials would be sampled once a year during low flow for analyses of minor elements. At continuous-record stations, water samples would be collected once-a-year during low flow for analyses of common constituents and minor elements. Rainfall gages would be installed near each continuous-record gaging station for the collection of continuous rainfall data. 
A plan to monitor strip-mining of lignite would need to be implemented soon after the opening of a mine is announced so that local baseline information could be collected in advance of any effects on the hydrologic system. . For ground water, additional observation wells would be installed near the mine site to monitor water levels in the aquifers affected. Single-well pumping tests would be conducted and water samples would be collected to provide additional information on values of transmissivity and ground-water guality. Recorders would be installed on a well in each aguifer affected, and periodic tape measurements would be made in the other wells. Pumps would be installed in wells down-gradient from the mine site for monitoring changes in ground-water guality. For surface water, a continuous-record stream-flow gaging station, a surfacewater quality monitor, and a automatic suspended-sediment sampler would be installed at two sites downstream from the mine, and a recording rain gage would be installed near the mine site. Other data to be collected would be surface-water quality surveys, seepage measurements, and channel crosssection surveys with photographs upstream and downstream from the mine site.

After several years of baseline data collection, sufficient data would be available for application of computer modeling technigues. Computer modeling would be a highly desirable tool for analyzing and interpreting large amounts of data and in predicting the effects of stripmining lignite on the hydrologic system. 
Born, K. E., 1936, Summary of the mineral resources of Tennessee: Tennessee Division of Geology Resources of Tennessee (ser. 2), 102 p.

Boswel1, E. H., Cushing, E. M., and Hosman, R. L., 1968, Quaternary aquifers in the Mississippi embayment, with a discussion of Quality of water by H. G. Jeffery: U.S. Geological Survey Professional Paper 448-E, p. El-El5.

Criner, J. H., and Parks, W. S., 1976, Historic water-level changes and pumpage from the principal aquifers of the Memphis area, Tennessee: 1886-1975: U.S. Geological Survey Water Resources Investigations $76-67,45 \mathrm{p}$.

Criner, J. H., Sun, P-C.P., and Nyman, D. J., 1964, Hydrology of the aguifer systems in the Memphis area, Tennessee: U.S. Geological Survey Water-Supply Paper 1779-0, p. 01-054.

Cushing, E. M., Boswell, E. H., and Hosman, R. L., 1964, General geology of the Mississippi embayment: U.S. Geological Survey Professional Paper 448-B, P. B1-B28.

Cushing, E. M., Boswell, E. H., Speer, P. R., Hosman, R. L., and others, 1970, Availability of water in the Mississippi embayment: U.S. Geological Survey Professional Paper 448-A, P. Al-Al3.

Dalsin, G. J., 1979, Plan for studies of lignite hydrology in Mississippi: U.S. Geological Survey Open-File Report 79-740, 39 p.

Fenneman, N. M. , 1938, Physiography of eastern United States: New York and London, MCGraw-Hi 11, $714 \mathrm{p}$.

Glenn, L. C., 1906, Underground waters of Tennessee and Kentucky west of Tennessee River and of an adjacent area in Illinois: U.S. Geological Survey Water Supply Paper $164,173 \mathrm{p}$.

Hardeman, W. D., Miller, R. A., and Swingle, G. D., compliers, 1966, Geologic map of Tennessee: Tennessee Division of Geology, scale $1: 250,000,4$ sheets

Hosman, R. L., Long, A. T., Lambert, T. W., and others, 1968, Tertiary aquifers in the Mississippi embayment, with discussions of quality of water by H. G. Jeffery: U.S. Geological Survey Professional Paper 448-D, p. D1-D29.

Kernodle, J. M., and Wilson, J. M., 1973, water use in Tennessee, 1970: Tennessee Division of Water Resources Water Use Series, no. 4, 102 p.

Krinitzsky, E. L., and wire, J. C., 1964, Ground water in alluvium of the Lower Mississippi Valley (upper and central areas): U.S. Army Engineer Waterways Experiment Station Technical Report No. 3-658(2v.), $100 \mathrm{p}$.

Lanphere, C. R., 1955, Geologic source and chemical quality of public ground-water supplies in western Tennessee: Tennessee Division of Geology Report of. Investigation 1, $69 \mathrm{p}$. 
Luppens, J. A., 1978, Exploration for Gulf Coast United States lignite deposits: Their distribution, quality, and reserves: Paper presented at the Second International Coal Exploration Symposium at Denver, Colorado, October 1-4, 1978.

Milhous, H.C., 1959, Well logs in Tennessee: Tennessee Division of Geology Bulletin 62, 606 p.

Miller, R. A., 1974, The geologic history of Tennessee: Tennessee Division of Geology Bulletin 74, 63 p.

Moore, G. K., 1965, Geology and hydrology of the Claiborne Group in western Tennessee: U.S. Geological Survey water-Supply Paper 1809-F, p. F1F4 4 .

Moore, G. K., and Brown, D. L., 1969, Stratigraphy of the Fort Pillow test well, Lauderdale County, Tennessee: Tennessee Division of Geology Report of Investigations 26.

Nelson, W. A., 1912, Lignite and lignite clay in west Tennessee: Tennessee Geological Survey Resources of Tennessee (ser. 1) v. 2, no. 4, p. $157-160$.

Nuttli, 0. W., 1974, The Mississippi Valley earthquakes of 1811 and 1812: U.S. Geological Survey Earthquake Information Bulletin, v. 6, no. 2, p. 8-13.

Parks, W. S., and Lounsbury, R. W., 1975, Environmental Geology of Memphis, Tennessee, in Field trips in West Tennessee: Tennessee Division of Geology Report of Investigations 36, p. 35-63.

Roberts, J. K., and Collins, R. L. [1928], The Tertiary and Quaternary geology of western Tennessee: Unpublished report on $f i l e$ in the Memphis office of U.S. Geological Survey and Nashville office of Tennessee Division of Geology, $336 \mathrm{p}$.

Russel1, E. E., and Parks, W. S., 1975, Stratigraphy of the outcropping Upper Cretaceous, Paleocene, and lower Eocene in western Tennessee (including descriptions of younger fluvial deposits): Tennessee Division of Geology Bulletin 75, 126 p.

Safford, J. M., 1869, Geology of Tennessee: Nashville, S. C. Mercer, $550 \mathrm{p}$.

Saucier, R. T., and others, 1964-78, Geological investigation of the St. Francis basin: U.S. Army Engineer Waterways Experiment Station Technical Report 3-659, folio of maps and cross-sections published at various dates, approx. 45 sheets.

Speer, P. R., Perry, W. J., McCabe, J. A., Lara, O. G., and others, 1965, Low-flow characteristics of streams in the Mississippi embayment in Tennessee, Kentucky, and Illinois, witr, a section on Quality of the water, by H. G. Jeffery: U.S. Geological Survey Professional Paper 448-H, P. Hl-H36. 
Strausberg, S. I., and Schreurs, R. L., 1958, Ground-water resources of the Mississippi alluvial valley of Tennessee: Unpublished report on file in the Memphis office of U.S. Geological Survey and Nashville office of Tennessee Division of Geology, $49 \mathrm{p}$.

Stearns, R. G., and Wilson, C. W., Jr., 1972, Relations of earthquakes and geology in west Tennessee and adjacent areas: Tennessee Valley Authority, $301 \mathrm{p}$.

Tennessee Department of Conservation, Division of Information and Education, 1977, Lignite exploration conducted: The Tennessee Conservationist, v. 63, November/December 1977 no. 8, p. vii.

Tennessee Department of Public Health, Stream Pollution Control Board, 1964-65, Ground-water survey of western Tennessee: $49 \mathrm{p}$.

Tennessee Valley Authority, Division of Water Control Planning, 1952, Preliminary report on Fulton site for Memphis area steam plant (revised ed.) : $37 \mathrm{p}$.

Terry, J. E., Bryant, C. T., Ludwig, A. H., and Reed, J. E., 1979a, Waterresources appraisal of the south-Arkansas lignite area: U.S. Geological Survey Open-File Report 79-924, 162 p.

Terry, J. E., Hosman, R. L., and Bryant, C. T., 1979b, Summary appraisals of the Nation's ground-water resources--Lower Mississippi Region: U.S. Geological Survey Professional Paper 813-N, P. N1-N4l.

U.S. Army Corps of Engineers, Memphis District [no date], Stages and discharges of the Mississippi River and tributaries in the Memphis District (annual reports 1964-76).

1978, Foundation report--Design, construction, and performance of the impervious cutoff at W. G. Huxtable Pumping Plant, Mariana, Arkansas: $50 \mathrm{p}$.

U.S. Army Corps of Engineers, Mississippi River Commission [no date], Stages of the Mississippi River and of its principal tributaries (annual reports 1925-42).

[no date], Stages and discharges of the Mississippi River and its outlets and tributaries (annual reports 1943-64).

U.S. Department of Commerce, National Oceanic and Atmospheric Administration [no date], Climatological data for Tennessee (monthly reports along with annual summaries through 1979).

U.S. Department of the Interior, office of Surface Mining, Reclamation and Enforcement, 1979, Surface coal mining and reclamation operations--permanent regulatory program: Federal Register, v. 44, no. 50, Tuesday, March 13, 1979, p. 15311-15463.

U.S. Geological Survey [no date], Groundwater levels in the United States --Southeastern States: U.S. Geological Survey Water Supply Paper(s) 1978, 2171, and 2165 (5-year summaries for 1964-68 and 1969-73 and annual summary for 1974 . 
U.S. Geological Survey, [no date] Surface water supply of the United States--Part 7, Lower Mississippi River basin: U.S. Geological Survey Water Supply Paper (annual reports 1888, 1900-60).

1961-64, Surface water records of Tennessee: U.S. Geological Survey Data Report. Issued annually.

1965-78, Water resources data for Tennessee: U.S. Geological Survey Data Report. Issued annually.

U. S. 95th Congress, 1977, Public law 95-87, 91 Statute 445, 88 p.

Wells, F. G., 1933, Ground-water resources of western Tennessee, with a discussion of the Chemical character of water by F. G. Wells and M. D. Foster: U.S. Geological Survey Water-Supply Paper 656, 319 p.

Whitlach, G. I., 1940, The clays of West Tennessee: Tennessee Division of Geology Bulletin 49, $368 \mathrm{p}$.

Williams, D. R., 1976, An investigation of the Tertiary lignites of Mississippi: Mississippi Geological, Economic and Topographical Survey Information Series MGS-74-1, $147 \mathrm{p}$. 